UNIVERSIDADE DE SÃO PAULO

INSTITUTO DE QUÍMICA DE SÃO CARLOS

SUMÁRIA SOUSA E SILVA

Aplicação de ramnolipídeo no controle de biofilmes de patógenos alimentares

São Carlos- SP

2016 
SUMÁRIA SOUSA E SILVA

\section{Aplicação de ramnolipídeo no controle de biofilmes de patógenos alimentares}

Tese apresentada ao Instituto de Química de São Carlos da Universidade de São Paulo como parte dos requisitos para obtenção do título de Doutora em Ciências.

Área de Concentração: Química Orgânica e Biológica

Orientadora: Prof ${ }^{\mathrm{a}}$. Dr ${ }^{\mathrm{a}}$. Marcia Nitschke

\section{Exemplar revisado}

0 exemplar original encontra-se em acervo reservado na Biblioteca do IQSC-USP

São Carlos- SP 

Ao meu querido e amado esposo Prof. Dr. José Wilson Pires Carvalho. 


\section{AGRADECIMENTOS}

Agradeço primeiramente a Deus pela força espiritual que me manteve firme para alcançar todos os objetivos até aqui pretendidos.

Ao meu querido companheiro e parceiro Prof. Dr. José Wilson Pires Carvalho que desde sempre acreditou em mim e fez com que esse doutorado se concretizasse de fato. $\mathrm{O}$ meu muito obrigada pelo amor, incentivo, paciência, apoio incondicional, tanto emocional, psicológico, como financeiro e também pela ajuda direta no desenvolvimento deste trabalho

Agradeço a minha orientadora Profa. Dra. Marcia Nitschke por sua orientação, amizade e incentivo. Como também, por sua disponibilidade e compreensão nos momentos necessários, sendo de fundamental contribuição para o desenvolvimento deste trabalho.

À minha família pela confiança, apoio e incentivo apesar da distância.

Ao grupo de "Biotecnologia Microbiana", em especial aos técnicos Marília Peret e João Pedro pelo suporte durante a rotina no laboratório, enriquecido com ensinamentos profissionais e pessoais. E também aos colegas de laboratório: Gabriela Carrega, Jorge Unás, Jakeline Ferreira, Crisiane Marangon, Cássia Watanabe, Débora Mayer, Márcio Bocelli, pelo apoio, companheirismo, risos e contribuição direta ou indireta na minha formação e no desenvolvimento deste trabalho.

Ao grupo de Biofísica Molecular do Instituto de Química de São Carlos- IQSC, em especial ao Prof. Dr. Marcel Tabak pela ajuda com o uso da técnica de Espalhamento Dinâmico de Luz - DLS.

Aos grupos de Biofísica Molecular e de Polímeros "Prof. Bernhard Gross", ambos pertencentes ao Instituto de Física de São Carlos- IFSC em especial às técnicas Derminda Isabel de Moraes (Bel) e a Dra. Débora Terezia Balogh, e ao amigo doutorando Éverton Edésio Dinis Silva pelo auxílio com a utilização de equipamentos e com as análises de DNA. 
Ao grupo de Bioquímica da Faculdade de Ciências Farmacêuticas de Ribeirão PretoFCFRP/USP, em especial à Profa. Dra. Carolina Patrícia Aires e a técnica Ana Cristina Morseli Polizello pela ajuda com as análises do material polimérico extracelular.

Ao Laboratório de Processos Biológicos (LPB) pertencente ao Departamento de Hidráulica e Saneamento da EESC- USP, em especial à técnica Dra. Eloisa Pozzi Gianotti pela ajuda com as análises de Microscopia de Fluorescência.

Ao Prof. Dr. Leandro Ramos Souza Barbosa do Instituto de Física de São Paulo IFUSP, pela ajuda com as análises de Espalhamento de Raios-X a Baixo Ângulo- SAXS

Ao Instituto de Química de São Carlos- IQSC /USP pelo suporte estrutural, acadêmico e financeiro.

A todos que de alguma forma contribuíram para a realização deste trabalho.

Muito Obrigada! 


\section{RESUMO}

SILVA, S. S. Aplicação de ramnolipídeo no controle de biofilmes de patógenos alimentares. 2016. 112 f. Tese (Doutorado em Ciências) - Instituto de Química de São Carlos, Universidade de São Paulo, São Carlos, 2016.

A formação de biofilme representa preocupação à indústria de alimentos pois é uma fonte crônica de contaminação. Encontrar estratégias eficientes para controlar o crescimento de microrganismos continua a ser um importante desafio. Uma delas é o uso dos ramnolipídeos (RLs), um biossurfatante produzido tipicamente por $P$. aeruginosa que apresenta potencial como agente antimicrobiano, anti-adesivo e dispersivo. Sua baixa toxicidade, biodegradabilidade, eficiência e especificidade em comparação aos surfatantes sintéticos podem torná-los promissores agentes de biocontrole. O presente estudo teve como objetivo estudar o potencial de uso de ramnolipídeos, em diferentes condições de concentração e temperatura, no controle e remoção de biofilmes de patógenos alimentares formados em meio de cultura e leite. Foram utilizadas Escherichia coli ATCC 43895, Listeria monocytogenes ATCC 19112, Staphylococcus aureus ATCC 8095, reconhecidos patógenos alimentares. Os biofilmes foram formados em placas de microtitulação de poliestireno nos meios de cultivo: caldo nutriente $(\mathrm{CN})$, extrato de levedura com triptona de soja (TSYE) e matriz alimentar (leite) à $37^{\circ} \mathrm{C}$, por $24 \mathrm{~h}($ E. coli $)$ e $48 \mathrm{~h}$ (S. aureus e L. monocytogenes). Os biofilmes foram avaliados pela quantificação da biomassa, viabilidade celular, hidrofobicidade de superfície e análises qualitativa (microscopia eletrônica de varredura e de fluorescência) e quantitativa (caracterização da matriz polimérica). O ramnolipídeo foi submetido à análise físico-química de espalhamento dinâmico de luz (DLS), espalhamento de raios-X a baixo ângulo (SAXS). Os resultados obtidos para $E$. coli mostraram que a concentração de RL que mais removeu o biofilme foi $2 \%$, porém em temperaturas diferentes, para o $\mathrm{CN}$ à $25^{\circ} \mathrm{C}$ e para o leite à $37^{\circ} \mathrm{C}$, com $33 \%$ e $80 \%$ de remoção, respectivamente. Para o biofilme de S. aureus em caldo nutriente os resultados mais eficientes foram à $25^{\circ} \mathrm{C}$, na concentração de $0,1 \%$ de RL e em leite $4{ }^{\circ} \mathrm{C}$, na concentração de $0,05 \%$ de RL, com remoção de $35 \%$ e $89 \%$, respectivamente. $\mathrm{O}$ biofilme de L. monocytogenes em TSYE mostrou-se mais sensível à $37^{\circ} \mathrm{C}$, na concentração $0,5 \%$ de RL, o qual foi possível remover $35,3 \%$ da biomassa. Enquanto que em leite a $4{ }^{\circ} \mathrm{C}$ e $0,5 \%$ de RL, com remoção de $63,6 \%$. Quanto à redução das células viáveis foi observado que para as bactérias Gram-positivas o tratamento mais efetivo foi à $4{ }^{\circ} \mathrm{C}$ com $0,05 \%$ de RL, nos meios CN e TSYEe $1 \%$ em leite. Para os biofilmes de E. coli a maior redução da viabilidade ocorreu em leite, após tratamento com RL $0,05 \%$ à $37{ }^{\circ} \mathrm{C}$. As imagens de microscopia mostraram uma morfologia heterogênea na presença dos diferentes meios de cultivos, com destaque para os biofilmes de $S$. aureus (leite) e L. monocytogenes (TSYE), nos quais houve grande produção de matriz polimérica extracelular (MPE), e também apresentaram as maiores quantidades de carboidratos e proteínas. O tratamento com o ramnolipídeo reduziu a hidrofobicidade dos biofilmes. As análises de DLS e SAXS mostraram uma predominância em número de micelas com diâmetro entre 1-10 nm, independente das concentrações e temperaturas analisadas. De modo geral, a aplicação de ramnolipídeo promoveu remoção da biomassa celular como também redução de células viáveis presentes no biofilme. As evidências obtidas aqui, podem ser importantes subsídios para futuras investigações sobre as interações físico-químicas entre ramnolipídeos e a camada de biofilme visando aplicação como agentes sanitizantes em indústria de alimentos.

Palavras-chaves: Biossurfatante; Poliestireno; Escherichia coli;Listeria monocytogenes; Staphylococcus aureus. 


\begin{abstract}
SILVA, S. S. Application of rhamnolipid to control food pathogens biofilms. 2016. $112 \mathrm{f}$. Thesis (Doctorate in Sciences) - Institute of Chemistry of São Carlos, University of São Paulo, São Carlos, 2016.

Biofilm formation is a concern to the food industry because it is a chronic source of contamination. Finding effective strategies to control the growth of microorganisms remains a major challenge. One strategy is the use of rhamnolipids (RLs), a biosurfactant typically produced by $P$. aeruginosa that has potential as antimicrobial, anti-adhesive and biofilm disrupting agent. RLs low toxicity, biodegradability, efficiency and specificity comparatively to synthetic surfactants, makes them promising biocontrol agents. This work aimed to study the potential use of rhamnolipid at different conditions of concentration and temperature, to control and removal of biofilms of food pathogens established in culture medium and milk. The bacterial strain utilized Escherichia coli ATCC 43895, Listeria monocytogenes ATCC 19112, Staphylococcus aureus ATCC 8095, are well-recognized food pathogens. The biofilms were formed in polystyrene microtiter plates in culture media: nutrient broth (NB), yeast extract and tryptone soya (TSYE) and in food matrix (milk) at $37{ }^{\circ} \mathrm{C}$ for $24 \mathrm{~h}$ (E. coli) and 48 $\mathrm{h}$ ( $S$. aureus and L. monocytogenes). Biofilms were assessed by biomassquantification, cell viability, surface hydrophobicity, qualitative (scanning electron microscopy and fluorescence) and quantitative (characterization of polymer matrix) analysis. The rhamnolipid was subjected to physical and chemical analysis of dynamic light scattering (DLS) and X-ray small angle scattering (SAXS). E. colibiofilms were removed more efficiently using $2 \% \mathrm{RL}$, but at different temperatures for $\mathrm{NB}\left(25^{\circ} \mathrm{C}\right)$ and milk $\left(37^{\circ} \mathrm{C}\right)$ showing $33 \%$ and $80 \%$ respectively. For the biofilm of $S$. aureus in NB the best results was obtained at $25^{\circ} \mathrm{C}$ and $0.1 \% \mathrm{RL}$ and in milk medium at $4{ }^{\circ} \mathrm{C}$ with $0.05 \%$ RL showing $35 \%$ and $89 \%$ of biofilm disruption, respectively. The biofilm of L. monocytogenes in TSYE was more sensitive to the treatment at $37{ }^{\circ} \mathrm{C}$ with $0.5 \% \mathrm{RL}$, removing $35.3 \%$ of the biofilm; while in milk at $4{ }^{\circ} \mathrm{C}$ and $0.5 \% \mathrm{RL}$, biofilm removal reached $63.6 \%$. Reduction on cell viability was more effective for Grampositive bacteria at $4{ }^{\circ} \mathrm{C}$ with $0.05 \% \mathrm{RL}$, for NB and TSYE and at $1 \%$ in milk. For E. coli biofilms the largest reduction of viability occurred in milk after treatment with $0.05 \% \mathrm{RL}$ at $37{ }^{\circ} \mathrm{C}$. The microscopy images showed a heterogeneous morphology in the presence of different media, especially biofilms of $S$. aureus (milk) and L. monocytogenes (TSYE), in which there was a great production of extracellular polymeric matrix (EPM), and also the highest amounts of carbohydrates and protein. The treatment with RL reduced the hydrophobicity of biofilms. The DLS and SAXS analysis of RL showed a predominance of micelles with diameters between 1-10 nm, independent of the concentrations and temperatures utilized. In general, the application of rhamnolipid promoted a reduction in biofilm mass as well in cell viability. The evidences obtained can provide a basis for future research on the physical and chemical interactions between rhamnolipid and biofilm layer aiming their application as sanitizers in food industry.
\end{abstract}

Keywords: Biosurfactant, Polystyrene; Escherichia coli; Listeria monocytogenes; Staphylococcus aureus. 


\section{LISTA DE FIGURAS}

Figura 1 - Morfologia das colônias da bactéria Escherichia coli. $\quad 24$

Figura 2 - Morfologia das colônias da bactéria Staphylococcus aureus. 26

Figura 3 - Morfologia das colônias da bactéria Listeria monocytogenes. 29

Figura 4 - $\quad$ Representação do ciclo de formação de biofilme em superfície abiótica. 33 Inicialmente a bactéria encontra-se na forma planctônica (livre) (1), posteriormente ocorre a adesão inicial (2), com crescimento e divisão ocorre adesões secundárias (3) e a formação da camada protetora constituindo o biofilme maduro (4) disperso por perdas de células (5) de acordo com as condições desfavoráveis a sua sobrevivência.

Figura 5 - $\quad$ Estrutura química do (A) mono-ramnolipídeo e do (B) di-ramnolipídeo, 37 com $m, n=6-18$.

Figura 6 - Aplicação de ramnolipídeo no controle de microrganismos. (a) Atividade 38 anti-adesiva, (b) Atividade antimicrobiana e (c) Remoção do biofilme préexistente em superfície biótica ou abiótica.

Figura 7 - $\quad$ Fluxograma das etapas de execução deste trabalho

Figura 8 - Esquema ilustrativo do método de diluições seriadas seguido de contagem em gotas em placas de Petri.

Figura 9 - Medidas do ângulo de contato entre uma gota de água e uma superfície sólida mostrando o grau de molhabilidade referente à cada perfil de gota.

Figura 10 - Procedimento de contagem pelo método de gota. (A) Escherichia coli ATCC 43895, (B) Staphylococcus aureus ATCC 8095 ambas em ágar nutriente e (C) Listeria monocytogenes ATCC 19112 em TSYEA.

Figura 11 - Estudo preliminar de formação de biofilme de E. coli ATCC 43895, S. 59 aureus ATCC 8095 e L. monocytogenes ATCC 19112, à $37{ }^{\circ} \mathrm{C}$ em microplaca de poliestireno.

Figura12 - Cinéticas de formação de biofilmes de E. coli ATCC 43895, S. aureus ATCC 8095 e L. monocytogenes ATCC 19112 em microplaca de poliestireno à $37^{\circ} \mathrm{C}$ usando (A) meio de cultura comercial e (B) leite.

Figura 13 - Quantificação da biomassa celular do biofilme de E. coli ATCC 43895 em 62 caldo nutriente (A) e leite (B), após o tratamento de 2 h com RL. Os dados representam a média de no mínimo três repetições independentes. 
Figura 14- Quantificação da biomassa celular do biofilme formado por S. aureus ATCC 8095, em caldo nutriente (A) e leite (B), após o tratamento de $2 \mathrm{~h}$ com RL. Os dados representam a média de no mínimo três repetições independentes.

Figura 15- Quantificação da biomassa celular do biofilme formado por L. 64 monocytogenes ATCC 19112, em TSYE (A) e leite (B), após o tratamento de $2 \mathrm{~h}$ com RL.Os dados representam a média de no mínimo três repetições independentes.

Figura 16- Cinética de viabilidade celular de E. coli ATCC 43895, usando o reagente resazurina à $25^{\circ} \mathrm{C}$, em células planctônicas $(\mathrm{A})$ e no biofilme $(\mathrm{B})$, em caldo nutriente (A1, B1) e em leite (A2, B2).

Figura 17- Cinética de viabilidade celular de S. aureus ATCC 8095, usando o reagente 68 resazurina à $25^{\circ} \mathrm{C}$, em células planctônicas $(\mathrm{A})$ e no biofilme (B), em caldo nutriente- $\mathrm{CN}$ (A1, B1) e em leite (A2, B2).

Figura 18- Cinética de viabilidade celular de L. monocytogenes ATCC 19112, usando o reagente resazurina à $25{ }^{\circ} \mathrm{C}$, em células planctônicas (A) e no biofilme (B), em extrato de levedura com triptona de soja - TSYE (A1, B1) e em leite (A2, B2).

Figura 19- Quantificação da viabilidade celular do biofilme formado por E. coli ATCC 43895 em caldo nutriente (A) e leite (B), após o tratamento de $2 \mathrm{~h}$ com RL. Os dados representam a média de no mínimo três repetições independentes.

Figura 20- Quantificação da viabilidade celular do biofilme formado por S. aureus ATCC 8095 em caldo nutriente (A) e leite (B), após o tratamento de $2 \mathrm{~h}$ com RL. Os dados representam a média de no mínimo três repetições independentes.

Figura 21- Quantificação da viabilidade celular do biofilme formado por L. 73 monocytogenes ATCC 19112 em caldo TSYE (A) e leite (B), após o tratamento de $2 \mathrm{~h}$ com RL. Os dados representam a média de no mínimo três repetições independentes.

Figura 22- Imagens das gotas de água sobre a superfície de poliestireno. Onde (A) 78 representa apenas o poliestireno sem biofilme; (B) poliestireno + biofilme formados na presença do meio caldo nutriente; $(\mathrm{C})$ poliestireno + biofilme formados em meio extrato de levedura com triptona de soja; (D) poliestireno+ biofilme formados em leite e (E) poliestireno+ biofilme após o tratamento com ramnolipídeo.

Figura 23- Eletromicrografias dos biofilmes de E. coli ATCC 43895 em caldo 82 nutriente,(A) Controle, (B) Tratado com $2 \%$ de RL à $25^{\circ} \mathrm{C}$ e em leite (C) Controle e (D) Tratado com $2 \%$ de RL à $37^{\circ} \mathrm{C}$. Aumento $2.000 \mathrm{X}$. 
Figura 24- Eletromicrografias dos biofilmes de S. aureus ATCC 8095 em caldo nutriente,(A) Controle, (B) Tratado com $0,1 \%$ de $\mathrm{RL}$ à $25^{\circ} \mathrm{C}$ e em leite (C) Controle e (D) Tratado com $0,05 \%$ de RL à $4{ }^{\circ} \mathrm{C}$. Aumento de 10.000X.

Figura 25- Eletromicrografias dos biofilmes de L. monocytogenes ATCC 19112 formados em Extrato de levedura com triptona de soja, sendo (A) o controle e (B) o tratamento com $0,5 \%$ de RL à $37{ }^{\circ} \mathrm{C}$ (Aumento de 10.000X) e em leite, sendo (C) o controle e (D) o tatamento com 0,5\% de $\mathrm{RL}$ à $4{ }^{\circ} \mathrm{C}$ (Aumento de 2.000X).

Figura 26- Microscopia de fluorescência de biofilmes de E.coli ATCC 43895, sobre superfície de poliestireno formados em meio $\mathrm{CN}$, onde (A e B) representam os controles e $(\mathrm{C}$ e $\mathrm{D})$ os tratamentos com $1 \%$ de $\mathrm{RL}$ à $25^{\circ} \mathrm{C}$, e em leite, onde $(\mathrm{E}$ e F) são os controles e $(\mathrm{G} \mathrm{e} \mathrm{H})$ os tratamentos com $0,05 \%$ de RL à $37^{\circ} \mathrm{C}$, (avaliados em $24 \mathrm{~h}$ ).

Figura 27- Microscopia de fluorescência de biofilmes de $S$. aureus ATCC 8095, sobre superfície de poliestireno formados em meio $\mathrm{CN}$, onde (A e B) representam os controles e $(\mathrm{C}$ e $\mathrm{D})$ os tratamentos com $0,05 \%$ de $\mathrm{RL}$ à $4{ }^{\circ} \mathrm{C}$, e em leite, onde $(\mathrm{E}$ e F) são os controles e $(\mathrm{G}$ e $\mathrm{H})$ os tratamentos com $1 \%$ de RL à 4 ${ }^{\circ} \mathrm{C}$, (avaliados em $48 \mathrm{~h}$ ).

Figura 28- Microscopia de fluorescência de biofilmes de L. monocytogenes ATCC 19112, sobre superfície de poliestireno formados em meio TSYE, onde (A e B) representam os controles e $(\mathrm{C}$ e D) os tratamentos com $0,05 \%$ de RL à $4{ }^{\circ} \mathrm{C}$, e em leite, onde (E e F) são os controles e $(\mathrm{G} \mathrm{e} \mathrm{H})$ os tratamentos com $1 \%$ de RL à $4{ }^{\circ} \mathrm{C}$, (avaliados em $48 \mathrm{~h}$ ).

Figura 29- Determinação da CMC para o ramnolipídeo (RL) em solução aquosa $\mathrm{pH}$ $7,0 \pm 0,2$.

Figura 30- Distribuição por tamanho de partículas $(\mathrm{nm})$ do ramnolipídeo por intensidade e número. As análises foram realizadas à $10^{\circ} \mathrm{C}(\mathrm{A}$ e $\mathrm{B}), 25^{\circ} \mathrm{C}$ $\left(\mathrm{C}\right.$ e D) e também à $37^{\circ} \mathrm{C}(\mathrm{E}$ e $\mathrm{F})$, variando as concentrações.

Figura 31- Curvas de SAXS para o ramnolipídeo nas concentrações de 0,25, 0,5, 1 e 293 $\%$. As análises foram realizadas nas temperaturas de $15^{\circ} \mathrm{C}$ (A) e $37^{\circ} \mathrm{C}(\mathrm{B})$.

Figura 32- Esquema representativo da ação do ramnolipídeo sobre os biofilmes formados por E. coli ATCC 43895, em caldo nutriente e em leite. Onde (A1 e B1) representam as melhores condições de remoção e (A2 e B2) as melhores condições de redução de viabilidade celular. Em verde células viáveis e em vermelho as não-viáveis. 
Figura 33- Esquema representativo da ação do ramnolipídeo sobre os biofilmes formados por S. aureus ATCC 8095, em caldo nutriente e em leite. Onde (A1 e B1) representam as melhores condições de remoção e (A2 e B2) as melhores condições de redução de viabilidade celular. Em verde células viáveis e em vermelho as não-viáveis.

Figura 34- Esquema representativo da ação do ramnolipídeo sobre os biofilmes formados por L. monocytogenes ATCC 19112, em extrato de levedura com triptona de soja e em leite. Onde (A1 e B1) representam as melhores condições de remoção e (A2 e B2) as melhores condições de redução de viabilidade celular. Em verde células viáveis e em vermelho as não-viáveis. 


\section{LISTA DE TABELAS}

Tabela 1 - Principais classes de biosurfatantes e microrganismos envolvidos.

Tabela 2 - $\quad$ Meios de cultura utilizados para crescimento bacteriano em placas de Petri.

Tabela 3 - $\quad$ Contagem do número de células viáveis $\left(\mathrm{UFC} \mathrm{mL}^{-1}\right)$ obtidas para os microrganismos de estudo.

Tabela 4 - $\quad$ Porcentagem de remoção dos biofilmes E. coli ATCC 43895 formados em caldo nutriente- $\mathrm{CN}$, após $2 \mathrm{~h}$ de tratamento com $\mathrm{RL}$ em diferentes condições de concentração e temperatura.

Tabela 5 - $\quad$ Porcentagem de remoção dos biofilmes E. coli ATCC 43895 formados em leite, após $2 \mathrm{~h}$ de tratamento com RL em diferentes condições de concentração e temperatura.

Tabela 6- $\quad$ Porcentagem de remoção dos biofilmes S. aureus ATCC 8095 formados em caldo nutriente- $\mathrm{CN}$, após $2 \mathrm{~h}$ de tratamento com RL em diferentes condições de concentração e temperatura.

Tabela 7- Porcentagem de remoção dos biofilmes S. aureus ATCC 8095 formados em leite, após $2 \mathrm{~h}$ de tratamento com RL em diferentes condições de concentração e temperatura.

Tabela 8- Porcentagem de remoção dos biofilmes L. monocytogenes ATCC 19112 formados em TSYE, após 2h de tratamento com RL em diferentes condições de concentração e temperatura.

Tabela 9- $\quad$ Porcentagem de remoção dos biofilmes L. monocytogenes ATCC 19112 formados em leite, após $2 \mathrm{~h}$ de tratamento com RL em diferentes condições de concentração e temperatura.

Tabela 10- $\quad$ Principais resultados de remoção dos biofilmes frente à ação de RL.

Tabela 11- Porcentagem de redução de células viáveis dos biofilmes E. coli ATCC 43895 em caldo nutriente (CN), após 2 h de tratamento com RL em diferentes condições de concentração e temperatura.

Tabela 12- $\quad$ Porcentagem de redução de células viáveis dos biofilmes E. coli ATCC 43895 em leite, após $2 \mathrm{~h}$ de tratamento com $\mathrm{RL}$ em diferentes condições de concentração e temperatura.

Tabela 13- $\quad$ Porcentagem de redução de células viáveis dos biofilmes $S$. aureus ATCC 8095 formados em caldo nutriente $(\mathrm{CN})$, após $2 \mathrm{~h}$ de tratamento com RL em diferentes condições de concentração e temperatura. 
Tabela 14- Porcentagem de redução de células viáveis dos biofilmes $S$. aureus ATCC 8095 formados em leite, após 2h de tratamento com RL em diferentes condições de concentração e temperatura.

Tabela 15- Porcentagem de redução de células viáveis dos biofilmes $L .73$ monocytogenes ATCC 19112 formados em caldo TSYE, após 2h de tratamento com RL em diferentes condições de concentração e temperatura.

Tabela 16- Porcentagem de redução de células viáveis dos biofilmes $L .73$ monocytogenes ATCC 19112 formados em leite, após $2 \mathrm{~h}$ de tratamento com RL em diferentes condições de concentração e temperatura.

Tabela 17- Principais resultados de redução de células viáveis dos biofilmes frente 74 à ação de RL.

Tabela 18- Relação entre os resultados de remoção da biomassa celular com os resultados de redução de viabilidade celular de todas as bactérias de estudo frente à ação do ramnolipídeo (RL).

Tabela 19- $\quad$ Medidas dos ângulos de contato dos biofilmes de E. coli ATCC 4389576 antes e após o tratamento com o ramnolipídeo.

Tabela 20- $\quad$ Medidas dos ângulos de contato dos biofilmes de S. aureus ATCC 77 8095 antes e após o tratamento com o ramnolipídeo.

Tabela 21- Medidas dos ângulo de contato dos biofilmes de L. monocytogenes ATCC 19112 antes e após o tratamento com o ramnolipídeo.

Tabela 22- Quantificação de carboidratos, proteínas e DNA extracelular presentes 80 na MPE dos biofilmes. 


\section{LISTA DE ABREVIATURAS E SIGLAS}

\begin{tabular}{|c|c|}
\hline A & Ampere \\
\hline Abs & Absorbância \\
\hline $\mathrm{AC}$ & Ângulo de contato \\
\hline ANOVA & Análise de variância \\
\hline ATCC & American Type Culture Collection \\
\hline A. U. & Unidade Arbitrária \\
\hline BSA & Albumina de soro bovina \\
\hline $\mathrm{BS}$ & Biossurfatante \\
\hline $\mathrm{CDC}$ & Centro de Controle e Prevenção de Doenças \\
\hline $\mathrm{CH}$ & Colites Hemorrágicas \\
\hline $\mathrm{CMC}$ & Concentração Micelar Crítica \\
\hline $\mathrm{CN}$ & Caldo Nutriente \\
\hline $\mathrm{CV}$ & Cristal violeta \\
\hline DO & Densidade óptica \\
\hline DLS & Espalhamento Dinâmico de Luz \\
\hline DTAs & Doenças transmitidas por alimentos \\
\hline EHEC & Enterohemorrágica \\
\hline EIEC & Enteroinvasivas \\
\hline EPEC & Enteropatogênicas \\
\hline ETEC & Enterotoxigênicas \\
\hline FDA & Food and Drug Administration \\
\hline $\mathrm{kV}$ & Quilovolt \\
\hline LPS & Lipopolissacarídeo \\
\hline $\mathrm{mA}$ & Miliampere \\
\hline $\mathrm{mM}$ & Milimolar \\
\hline $\mathrm{mN} \mathrm{m}^{-1}$ & Milinewton por metro \\
\hline MEV & Microscopia Eletrônica de Varredura \\
\hline $\mathrm{mL}$ & Mililitro \\
\hline MPE & Matriz Polimérica Extracelular \\
\hline
\end{tabular}




$\begin{array}{ll}\text { nm } & \text { Nanômetro } \\ \text { OMS } & \text { Organização Mundial de Saúde } \\ \text { pA } & \text { Picoampere } \\ \text { PTT } & \text { Púrpura Trombocitopênica } \\ \text { p/v } & \text { Peso/volume } \\ \text { pH } & \text { Potencial hidrogeniônico } \\ \text { RL } & \text { Ramnolipídeo } \\ \text { rpm } & \text { Rotação por minuto } \\ \text { SHU } & \text { Síndrome Hemolítica Urêmica } \\ \text { TS } & \text { Tensão Superficial } \\ \text { TSYE } & \text { Extrato de levedura com triptona de soja } \\ \text { TSYEA } & \text { Extrato de levedura com triptona de soja e ágar } \\ \text { UFC } & \text { Unidades Formadoras de Colônias } \\ \text { UV } & \text { Ultravioleta } \\ \text { v/v } & \text { Volume/volume } \\ \mu \mathrm{L} & \text { Microlitro } \\ \mu \mathrm{m} & \text { Micrômetro } \\ \mu \mathrm{g} & \text { Micrograma }\end{array}$




\section{SUMÁRIO}

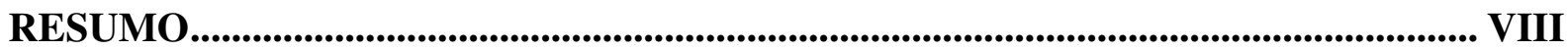

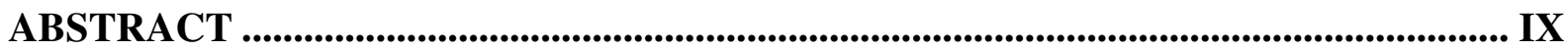

LISTA DE FIGURAS..........................................................................................................

LISTA DE TABELAS ................................................................................................................XIV

LISTA DE ABREVIATURAS E SIGLAS ..........................................................................XVI

1 INTRODUÇÃO ..........................................................................................................................................20

2 REVISÃO BIBLIOGRÁFICA .......................................................................................22

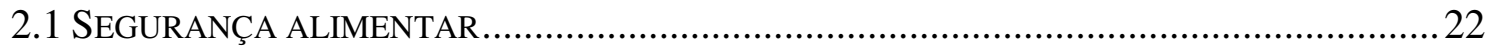

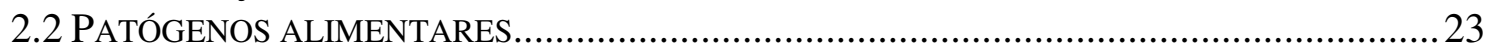

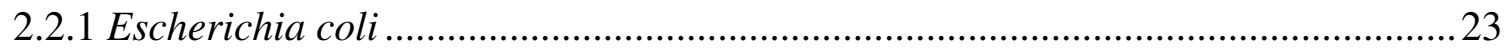

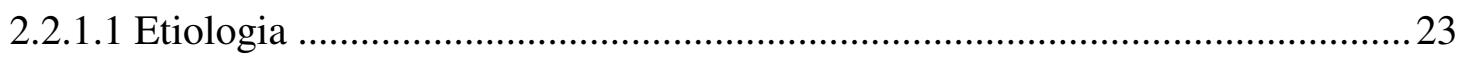

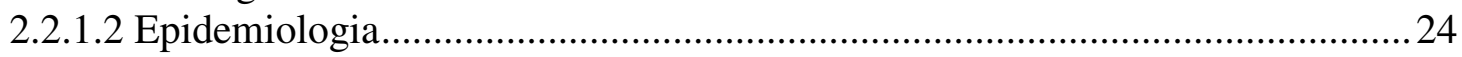

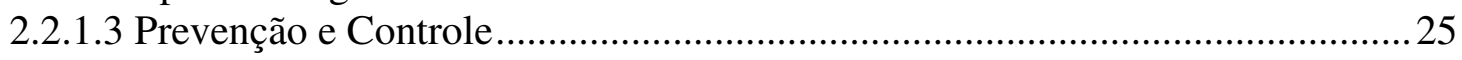

2.2.2 Staphylococcus aureus ……………………………………………………26

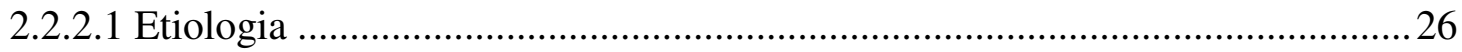

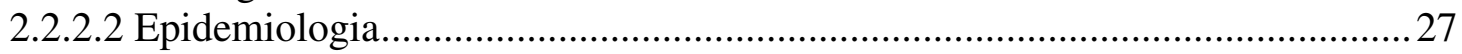

2.2.2.3 Prevenção e Controle ...................................................................................2

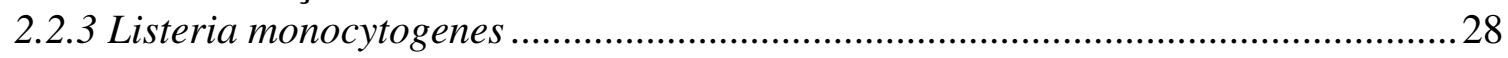

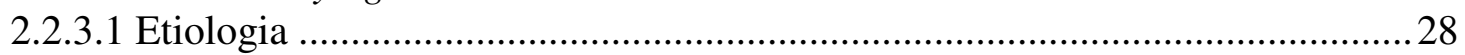

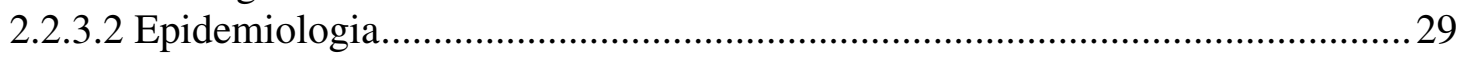

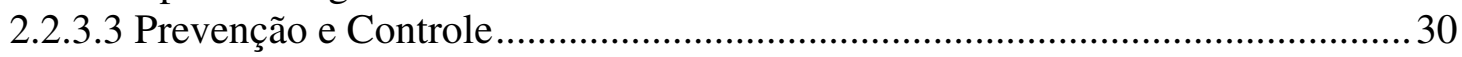

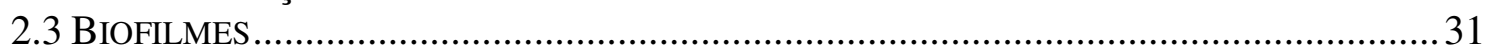

2.3.1 Formação dos biofilmes ...........................................................................................

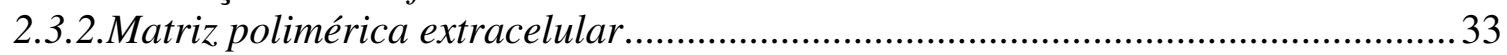

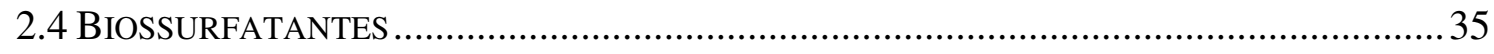

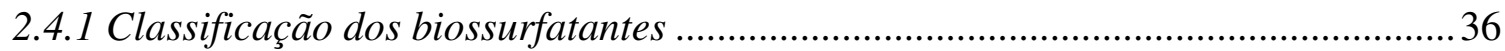

2.4.2 Ramnolipídeos: estrutura, propriedades e aplicações ................................................37

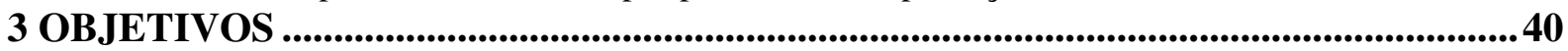

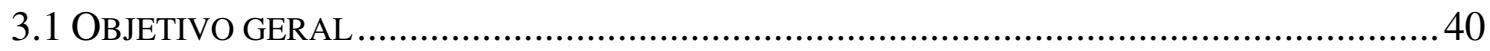

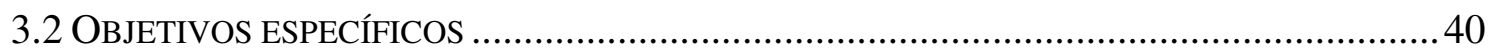

4 MATERIAIS E MÉTODOS …......................................................................41

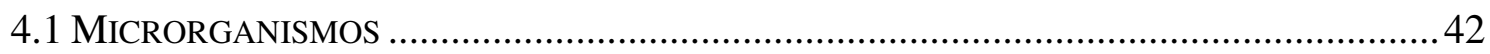

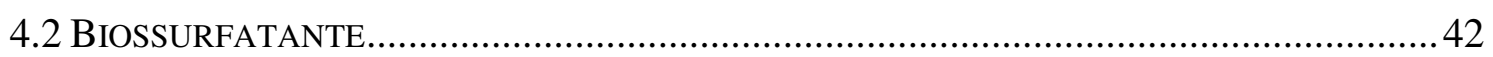

4.2.1 Preparo das soluções de ramnolipídeo …………………………………………...42

4.3 PREPARO DOS MEIOS DE CULTURA.........................................................................4

4.4 PREPARO E MANUTENÇÃo DOS ESTOQUES DOS MICRORGANISMOS DE ESTUDO.............43

4.5 PADRONIZAÇÃO DOS INÓCULOS BACTERIANOS.........................................................4

4.6 ENSAIO DE FORMAÇÃO DOS BIOFILMES EM POLIESTIRENO............................................4 45

4.7 TRATAMENTO DOS BIOFILMES COM RAMNOLIPÍDEO: EFEITO DA TEMPERATURA,

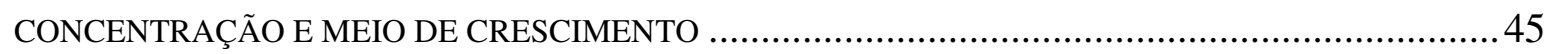

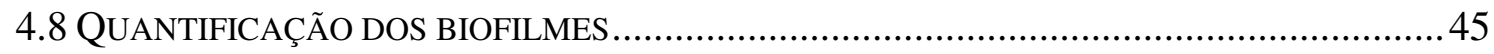

4.8.1 Biomassa celular ............................................................................................. 45

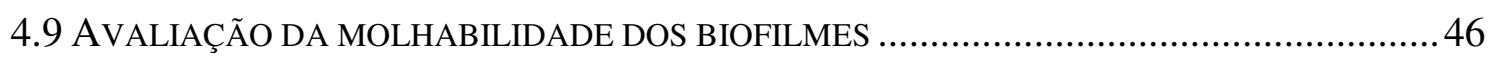

4.10 ANÁLISE BIOQUÍMICA DA MATRIZ POLIMÉRICA EXTRACELULAR ……………….......4 48

4.10.1 Obtenção do peso seco da matriz do biofilme ………………………………........4

4.10.4 Quantificação de DNA extracelular ...................................................................50 


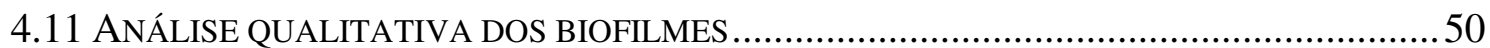

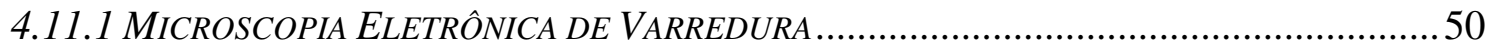

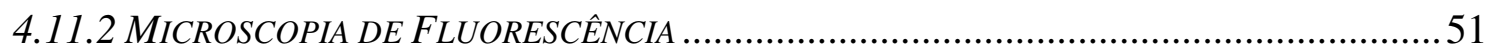

4. 12 ANÁLISE DAS PROPRIEDADES FÍSICO-QUÍMICAS DO RAMNOLIPÍDEO .........................52

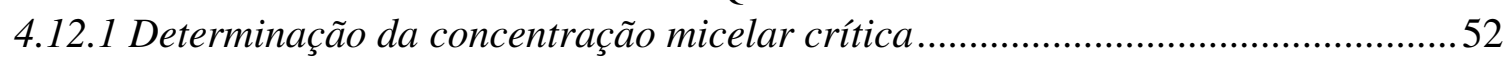

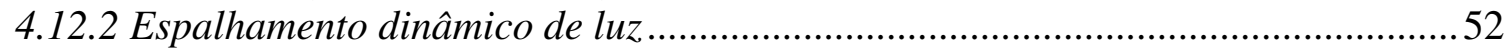

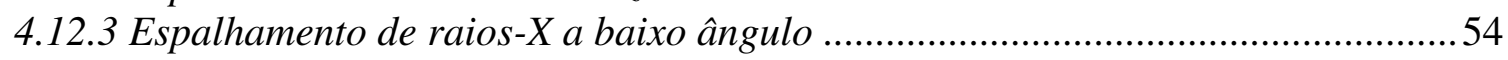

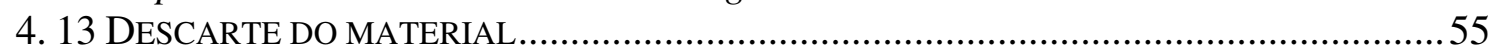

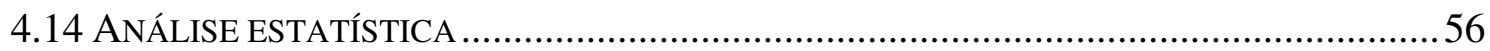

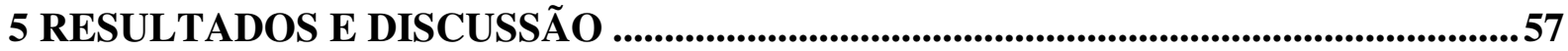

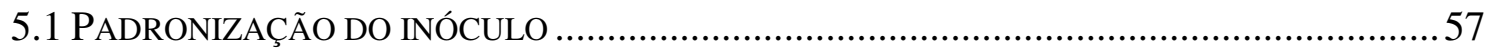

5.2 FORMAÇÃO E CARACTERIZAÇÃO DOS BIOFILMES FORMADOS PELOS DIFERENTES

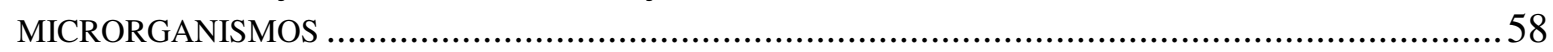

5.4 ANÁLISE DO TRATAMENTO DOS BIOFILMES COM RAMNOLIPÍDEO ...............................60

5.4.1 Quantificação da biomassa celular: influência da temperatura, meio de cultivo e

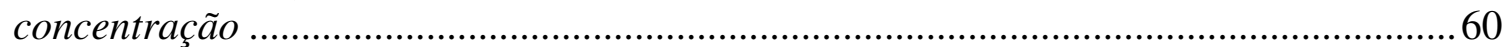
5.4.2 Análises de viabilidade celular:cinéticae influência da temperatura, meio de cultivo e concentraçãode ramnolipídeo ..............................................................................6 66

5.6 CARACTERIZAÇÃO DOS BIOFILMES ANTES E APÓS O TRATAMENTO COM RAMNOLIPÍDEO

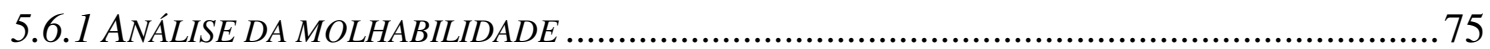

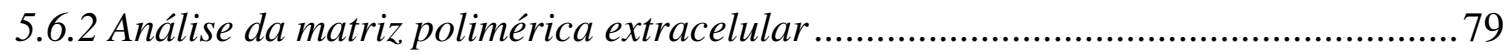

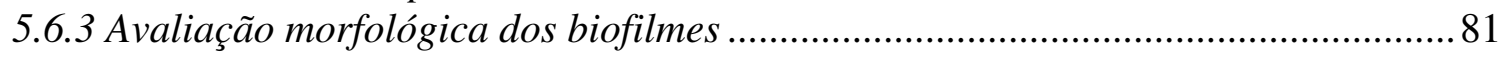

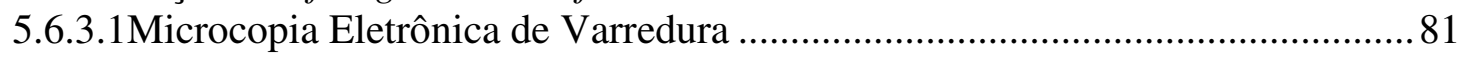

5.6.3.2 Microscopia de Fluorescência ......................................................................... 85

5.8.1 Determinação da concentração micelar crítica do ramnolipídeo ............................ 88

5.8.2 Análise físico-química do comportamento das micelas de ramnolipídeo: efeitos da

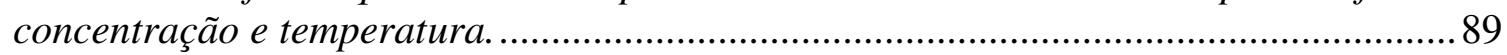

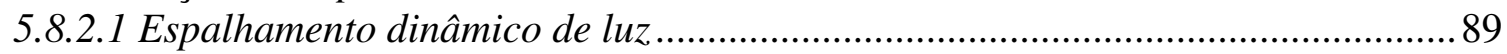

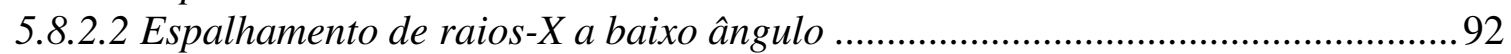

5.9 PRINCIPAIS RESULTADOS PARA CADA BACTÉRIA DE ESTUDO ......................................94

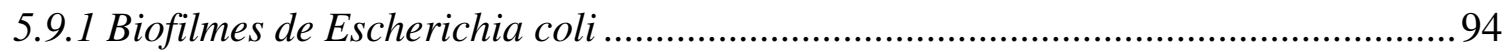

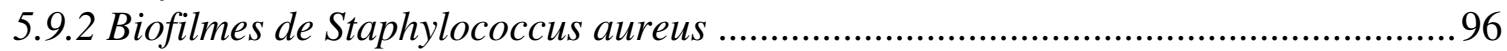

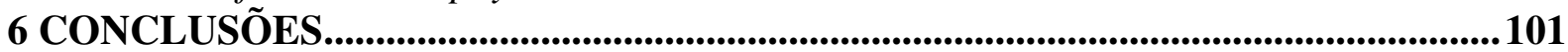

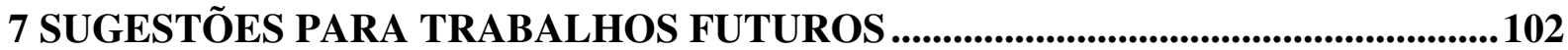

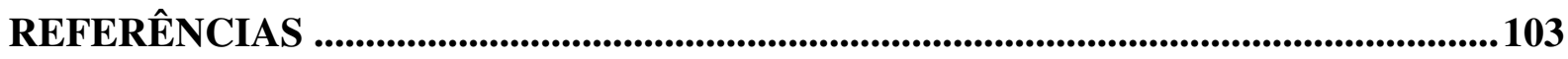




\section{INTRODUÇÃO}

A ocorrência de infecções alimentares devido à ingestão de produtos contaminados por microrganismos patogênicos ainda são recorrentes, apesar do grande desenvolvimento tecnológico dos últimos anos, especialmente na indústria alimentícia. Esses microrganismos patogênicos representam uma preocupação constante pela sua capacidade em resistir a tratamentos antimicrobianos e às desinfecções convencionais causando a deterioração e a perda da qualidade dos produtos, e ao mesmo tempo ameaçando a saúde do consumidor (PINTO, 1996). Alguns desses patógenos possuem a capacidade de formar uma comunidade complexa e estruturada denominada de biofilme, onde os microrganismos encontram-se envoltos por uma matriz polimérica extracelular (MPE), aderidos entre si e a superfícies biótica ou abiótica. Esta matriz protege os microrganismos contra a ação de antibióticos, alterações de pH, temperatura, choques osmóticos e desidratação (VU et al., 2009). Dentre os microrganismos que podem formar biofilmes, com potencialidade de acarretar problemas de saúde pública ou de ordem econômica, destacam-se os gêneros Staphylococcus, Salmonella, Enterococcus, Listeria, Escherichia, Bacillus e Clostridium (CHMIELEWSKI; FRANK, 2003; PLAKUNOV et al., 2010).

Diante desta problemática tornam-se necessários estudos de novos agentes que possam controlar o crescimento ou até mesmo remover os biofilmes já estabelecidos contribuindo com a qualidade e segurança de produtos e processos. Visto que as células quando associadas a um biofilme apresentam maior resistência a agentes antimicrobianos e detergentes do que quando livres. Uma alternativa para controle de patógenos alimentares é o uso de Biossurfatantes (BS), que compreendem um grupo diverso de moléculas anfipáticas com estruturas químicas diferentes, produzidos por vários microrganismos. Estas moléculas são formadas principalmente como metabólitos secundários e desempenham papéis críticos na sobrevivência de microrganismos, agindo como agentes biocidas que podem não só reduzir a sobrevivência dos microrganismos contaminantes, mas eliminar os biofilmes (GUDINÃ et al., 2013). A principal vantagem do uso de biossurfatantes em comparação aos tensoativos sintéticos reside na natureza biodegradável e baixa toxicidade aliada a atividade tensoativa e emulsificante (BANAT et al., 2010). Quando aplicados a superfícies de materiais, demonstraram propriedades antiadesivas, ou seja são capazes de reduzir a adesão microbiana e consequentemente o estabelecimento de biofilmes. Além disso, também apresentam ação 
antimicrobiana frente a patógenos como Listeria monocytogenes sugerindo que podem ser utilizados como agentes multi-propósito na indústria de alimentos (MAGALHÃES; NITSCHKE, 2013).

Os principais microrganismos envolvidos na produção de biossurfatantes são as bactérias, fungos e leveduras, como por exemplo: Pseudomonas aeruginosa que produz os ramnolipídeos, Bacillus subtilis a surfactina, Acinetobacter calcoaceticuso emulsan, fungos do gênero Ustilago e leveduras do gênero Pseudozyma que produzem o mannosileritritol, e os soforolipídeos produzidos pela levedura Candida bombicola já utilizados comercialmente em alguns países (MARCHANT; BANAT, 2012).

De todos os biossurfatantes conhecidos atualmente, os ramnolipídeos são considerados os BS de maior potencial de mercado (MÜLLER et al., 2012). Eles têm sido relatados como um substituto para surfatantes químicos nas indústrias de petróleo e produtos petrolíferos e na biorremediação de ambientes contaminados com óleo (BANAT et al., 2014). Apesar de seu potencial, há poucos estudos sobre as interações de ramnolipídeos com células bacterianas e seu papel antiadesivo e dispersante em biofilmes (DUSANE et al., 2010).

Em trabalho recente realizado por Kim e colaboradores (2015) investigou-se pela primeira vez as interações físico-químicas envolvidas entre os ramnolipídeos e o biofilme de $P$. aeruginosa. Entretanto, ainda não há relatos de interações entre o ramnolipídeo e a matriz polimérica extracelular, que constitue o biofilme formada por patógenos alimentares, como: Escherichia coli, Staphylococus aureus e Listeria monocytogenes. Tampouco investigação de fatores importantes como a eficiência da remoção dos biofilmes sob diferentes condições de temperatura, concentração e meio de cultivo. Destaca-se ainda que a maioria dos trabalhos envolvendo remoção de biofilmes por biossurfatantes apresenta conotação médica e/ou ambiental e não há relatos de sua utilização em biofilmes formados em matriz alimentar.

Nesse contexto, a presente tese de doutorado teve como objetivo estudar a potencialidade de aplicação dos ramnolipídeos no controle e remoção de biofilmes formados por bactérias patogênicas de importância alimentar. 


\section{REVISÃO BIBLIOGRÁFICA}

\subsection{Segurança alimentar}

Doenças transmitidas por alimentos, conhecidas como DTAs, são causadas pela ingestão de alimentos ou bebidas contaminados. Os microrganismos são considerados as principais fontes de doenças transmitidas por alimentos, pois desenvolvem resistência e são capazes de sobreviver em ambientes extremos, de $\mathrm{pH}$, temperatura e pressão, durante a produção e operações de processamento de alimentos (DONNENBERG, 2013). Existem mais de 250 tipos de DTAs, as quais podem ser provocadas por diversos grupos de microrganismos, incluindo bactérias, vírus, leveduras e fungos. As bactérias, pela sua diversidade e patogenia, constituem o grupo microbiano mais importante e mais comumente associado às doenças transmitidas por alimentos. As principais bactérias associadas a esse tipo de contaminação são: Clostridium sp., Bacillus cereus, Staphylococcus aureus, Escherichia coli, Salmonella sp., Listeria monocytogenes, Campylobacter sp., Shigella sp., Yersinia sp., Vibrio sp.entre outras, sendo que os sintomas mais comuns são vômitos, diarréias, náuseas e dores abdominais (HALL-STOODLEY et al., 2004; PINTO, 1996).

As doenças de origem alimentar, em especial as que são provocadas por microrganismos patogênicos, constituem um problema de saúde pública cuja magnitude é elevada, embora o conhecimento da situação seja inferior à realidade devido ao subdiagnóstico e sub-notificação. A Organização Mundial de Saúde (OMS) estima que o conhecimento oficial das doenças de origem alimentar seja de $10 \%$ em relação ao total de ocorrências. Este fenômeno é comum a todos os países, incluindo os mais desenvolvidos, o que torna a questão da segurança alimentar um dos grandes desafios globais enfrentados atualmente (KALYOUSSEF; FEJA, 2014; McENTIRE, 2013).

Apesar do progresso nas pesquisas em ciência e tecnologia dos alimentos, há uma crescente preocupação sobre segurança alimentar, pois a prevalência de doenças transmitidas por alimentos continua a ser uma causa importante de morbidade e morte evitável. Surtos nos Estados Unidos, Austrália, Alemanha, e Índia são indícios da gravidade do problema. Cerca de $30 \%$ da população nestes países sofrem de doenças transmitidas por alimentos a cada ano (McENTIRE, 2013). A prevalência destas doenças (toxinfecções /intoxicações alimentares) é 
influenciada por diversos fatores como: alterações ambientais, industrialização, urbanização, comércio internacional, aumento da cadeia alimentar, atitudes e comportamentos dos manipuladores de alimentos, e a pouca ou ineficaz sanitização em indústrias alimentícias (DONNENBERG, 2013).

\subsection{Patógenos alimentares}

O Centro de Controle e Prevenção de Doenças (CDC, 2011) estima que 31 patógenos principais promovam 9,4 milhões de casos de doença alimentar anualmente. Os vírus apresentam-se na maioria dos casos (59\%), seguido por bactérias $(39 \%)$ e parasitas (2\%). Embora os vírus estiveram envolvidos na maior parte das doenças foram as bactérias que promoveram $64 \%$ das internações; entre elas algumas espécies como: Salmonella (35\%) e Campylobacter sp. (15\%) que juntas representam metade de todos os casos. Dentre as 1.351 mortes por ano nos Estados Unidos, a maioria (64 \%) foram causadas por bactérias, sendo as mais comuns as espécies Salmonella não-tifóide (28\%) e Listeria monocytogenes (19 \%). Estima-se que 38 milhões de casos de gastroenterites, 71.000 hospitalizações e quase 1.700 mortes a cada ano podem ser causados por agentes não especificados (BRADEN; TAUXE, 2013). Grande parte dessas ocorrências deve-se à capacidade de sobrevivência e persistência de microrganismos em superfícies de contato com alimentos desempenhando um papel crucial na epidemiologia de doenças de origem alimentar (BURGESS et al., 2014).

\subsubsection{Escherichia coli}

\subsubsection{Etiologia}

Escherichia coli é uma bactéria Gram-negativa, em forma de bacilo, anaeróbica facultativa, não produz esporos e possui múltiplos flagelos dispostos em volta da célula (Figura 1). A maioria das linhagens de E. coli não são patogênicas, sendo comum na microbiota do trato gastrointestinal de animais e seres humanos (MADIGAN et al., 2010). Cerca de $10 \%$ a $15 \%$ das estirpes de E. coli são oportunistas ou patógenos capazes de causar doenças de origem alimentar (CAPITA et al., 2014). Contudo, algumas linhagens patogênicas transmitidas principalmente por alimentos apresentam capacidade de produzir potentes enterotoxinas, e causar doenças diarréicas de risco à vida e infecções do trato urinário (VISVALINGAM; HOLLEY, 2013). 


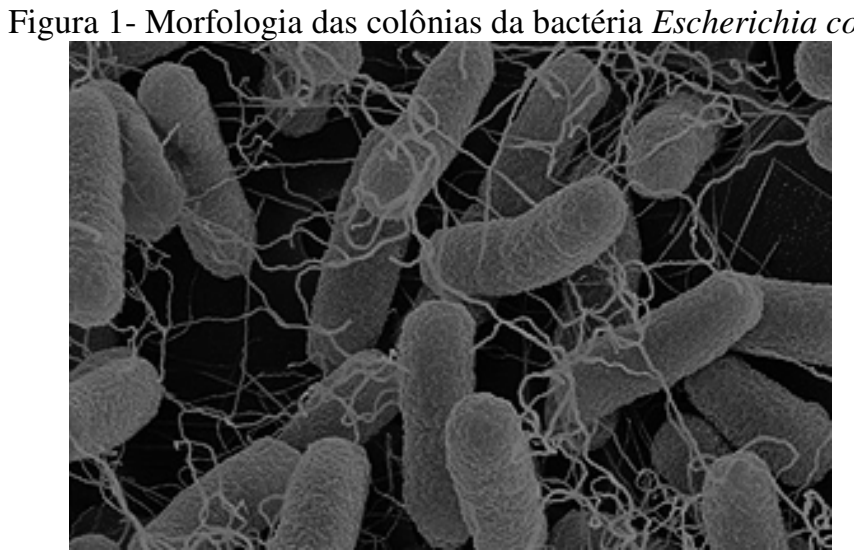

FONTE: Food and Drug Administration (FDA-EUA), 2013

As linhagens patogênicas de E. coli são divididas em categorias de acordo com o tipo de toxina produzida e das doenças que causam. Podem ser classificadas em: enterohemorrágica (EHEC), enterotoxigênicas (ETEC), enteropatogênicas (EPEC) e enteroinvasivas (EIEC). E.coli produtoras de toxinas Shiga (STEC) formam um grupo de bactérias patogênicas envolvidas em surtos de DTAs, do qual a E. coli enterohemorrágica constitui um subtipo (PAULA; CASARIN; TONDO, 2014).

O termo E. coli enterohemorrágica é utilizado para as cepas que provocam Colites Hemorrágicas $(\mathrm{CH})$, Síndrome Hemolítica Urêmica (SHU) ou Púrpura Trombocitopênica (PTT). De acordo com essa definição, todas as cepas de EHEC são patogênicas e constituem um importante grupo de patógenos emergentes transmitidos por alimentos principalmente o sorotipo utilizado neste estudo, a E. coli $0157: H 7$. Este produz verotoxina, uma enterotoxina similar àquela produzida por Shigella dysenteriae, a toxina Shiga, que causa tanto diarréia hemorrágica como insuficiência renal. Dentre os diversos sorotipos de EHEC a E. coli O157:H7 é o mais importante no que se refere à saúde pública (JAGLIC et al., 2014).

\subsubsection{Epidemiologia}

As infecções por Escherichia coli O157:H7 podem ser endêmicas ou epidêmicas e têm distribuição mundial. Estudos mostram que cepas desse sorotipo já foram isoladas em todos os continentes, abrangendo mais de 30 países. Porém, a maioria dos surtos epidêmicos têm sido registrados em países altamente industrializados como: Estados Unidos, Canadá, Japão, Inglaterra e Alemanha. O primeiro surto causado por E. coli O157:H7 em humanos foi relatado nos Estados Unidos, em 1982, quando esse microrganismo causou dois surtos de 
diarréia sanguinolenta severa, envolvendo pelo menos 47 pessoas. Isso ocorreu após a ingestão de sanduíches contendo hambúrgues de carne bovina, molho de cebola e picles, distribuídos em rede de fast-food. No entanto, foi somente em 1992 que E. coli O157:H7 foi reconhecido como patógeno alimentar emergente, quando mais de 700 pessoas em surto de colite hemorrágica resultando na morte de quatro crianças. Esse fato ocorreu após a ingestão de hambúrgueres preparados com carne moída mal tratada termicamente, em uma lanchonete de uma granderede de fast-food também nos Estados Unidos (MITTELSTAEDT; CARVALHO, 2006).

O maior surto causado por E. coli O157:H7 registrado até hoje ocorreu em 1996, na cidade de Sakai, localizada na província de Osaka, no Japão. Na ocasião, brotos de rabanete branco, servidos como parte do almoço de uma escola, foram identificados como veículo mais provável da infecção. Neste surto, mais de 8.000 pessoas foram envolvidas, principalmente crianças. Um total de 106 crianças desenvolveu Síndrome Hemolítica Urêmica (SHU) e três delas morreram (MITTELSTAEDT; CARVALHO, 2006).

No hemisfério sul, países como Argentina, Uruguai, Chile, Austrália e África do Sul têm descrito casos de infecção por EHEC. Na Argentina por exemplo a SHU causada por $E$. coli O157:H7 é considerada uma doença endêmica, tendo um dos índices globais mais altos. No Brasil, não houve ainda registros sistematizados de surtos epidêmicos de doença causada pela E. coli sorotipo O157:H7. Embora este sorotipo já tenha sido isolado, nunca foi relacionado a um grande número de casos. Como descrito acima, nos países vizinhos como Argentina, Chile e Uruguai, as infecções por EHEC são relativamente frequentes. Esta diferença pode estar relacionada a uma proteção imunológica causada pelas infecções por outro tipo de E. coli patogênica, as $\operatorname{EPEC~(E.~coli~enteropatogênica),~que~são~bastante~}$ frequentes no Brasil (MITTELSTAEDT; CARVALHO, 2006; PAULA; CASARIN; TONDO 2014).

\subsubsection{Prevenção e Controle}

A contaminação dos alimentos pode ocorrer em ambientes de processamento através de contaminação cruzada de matérias-primas ou de superfícies de contato com alimentos contaminados, indicadores de mínimas condições de higiene e saneamento (CAPITA et al., 
2014). Estes fatores podem está atrelados ao fato de algumas linhagens de E. coli apresentarem a capacidade de formar biofilmes em diversas superfícies como: vidro, aço inoxidável, polietileno de alta densidade, poliamida, teflon, lã de vidro e poliestireno (FAILLE, et al., 2002).

No entanto, sabe-se que a causa mais comum destes surtos são o consumo de carne bovina contaminada durante o abate ou processamento inadequados, quando as bactérias intestinais contaminam a carcaça ou a carne moída; a ingestão de leite cru, através da contaminação do úbere das vacas ou dos equipamentos de ordenha com conteúdo fecal. Entre outras fontes de infecção conhecidas estão os brotos de alfafa, alface, salame, leite e sucos não pasteurizados, e nadar ou beber em água contaminada por esgoto (não tratado). A transmissão pessoa-pessoa também é relatada se os hábitos de higiene ou lavagem de mãos não forem adequados (MADIGAN et al., 2010).

\subsubsection{Staphylococcus aureus}

\subsubsection{Etiologia}

Staphylococcus aureus é uma bactéria Gram-positiva em forma de cocos que em geral apresenta arranjo na forma de cachos, não formam endósporos (Figura 2) e podem causar uma variedade de doenças como: acne, pneumonia e meningite, apesar de fazer parte da microbiota normal do trato respiratório superior e da pele (MADIGAN et al., 2010).

Figura 2- Morfologia das colônias da bactéria Staphylococcus aureus.

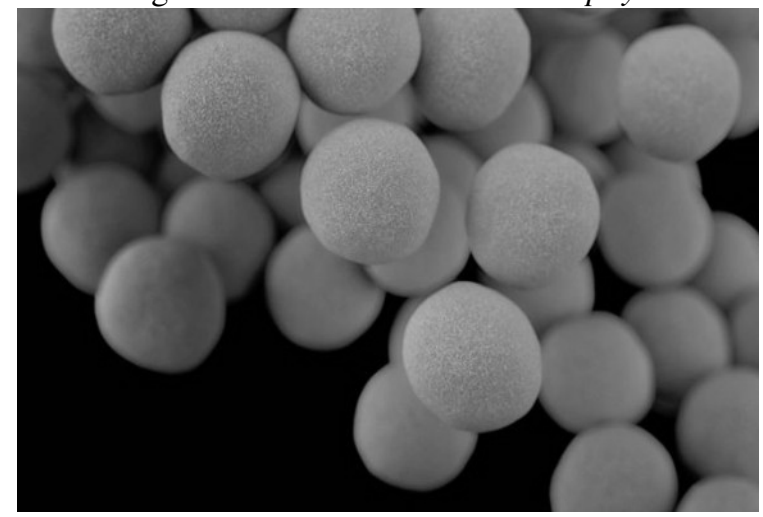

FONTE: Food and Drug Administration (FDA-EUA), 2013 
É um patógeno humano comum responsável pela intoxicação de origem alimentar em todo o mundo, causada pela ingestão de alimentos contendo enterotoxinas estafilocócicas termoestáveis (PIMENTEL- FILHO et al., 2014). Essas enterotoxinas estafilocócicas são proteínas simples, resistentes à hidrólise por enzimas gástricas e jejunais, e são estáveis ao aquecimento a $100{ }^{\circ} \mathrm{C}$ por um período determinado. Apresentam também resistência pela cocção normal, pasteurização e a outros tratamentos térmicos usuais. Elas foram identificadas com base em métodos sorológicos, e denominadas de A, B, C1, C2, C3, D, E, G, H e I (DINGES et al., 2000). A enterotoxina do tipo A é a mais frequentemente associada à gastrenterite estafilocócica e na liberação de mediadores inflamatórios, cujo os principais sintomas resultantes são:cólicas abdominais, náuseas, vômitos e diarréia (CICCIO et al., 2015; MADIGAN et al., 2010).

\subsubsection{Epidemiologia}

Os Staphylococcus têm sido isolados esporadicamente de uma grande variedade de fontes que incluem: solo, água, areia da praia, ar e alimentos, entre outras. A contaminação microbiológica dos alimentos tem sido objeto de preocupação constante em diversos países. Nos Estados Unidos, estima-se que, anualmente, cerca de 1 a 2 milhões de pessoas são acometidas com gastrenterites provocadas por toxinas de $S$. aureus presentes, sobretudo, em produtos de origem animal. No Brasil, segundo dados do Ministério da Saúde, foram registrados 593.212 casos de intoxicação alimentar entre 1984 e 1997, porém sem especificar as toxinas, os microrganismos ou as fontes envolvidas. Estes dados, possivelmente subestimados devido à falta de notificação dos surtos, demonstram a relevância das medidas de controle sanitário dos alimentos destinados ao consumo humano, particularmente das matérias primas de origem animal (FAGUNDES; OLIVEIRA, 2004).

\subsubsection{Prevenção e Controle}

Ao longo dos processos industriais $S$. aureus pode se fixar em superfícies de contato, durante a manipulação de alimentos podendo contaminar diversos produtos. Isso ocorre, devido a vários fatores, um deles é que essa bactéria não compete com a microbiota presente nos alimentos crus (JAGLIC et al., 2014). Isso indica que as contaminações podem estar associadas principalmente com manipulação imprópria de alimentos cozidos ou processados, seguido de armazenamento sob condições que permitem o crescimento de S. aureus. Outro 
fator é a capacidade que algumas estirpes apresentam de formar biofilmes em superfícies de processamento de alimentos o que facilita acontaminação cruzada de alimentos (PIMENTELFILHO et al., 2014; VÁZQUEZ-SÁNCHEZ et al., 2013).

Estudos monstraram que a fixação de $S$. aureus pode ocorrer em diferentes superfícies de trabalho tais como: poliestireno, polipropileno, aço inoxidável, vidro e também em produtos alimentares. Contudo, alterações nas propriedades físico-químicas da superfície do substrato e topografia, bem como fatores ambientais como a osmolaridade, nutrientes e temperatura podem levar ao desenvolvimento de biofilme estafilocócica e, consequentemente, influenciar na sua persistência nos ambientes em contato com alimentos (VÁZQUEZSÁNCHEZ et al., 2013). O entendimento dessas interações é extremamente importante para controlar ou até mesmo evitar tais problemas.

Os alimentos mais habitualmente envolvidos incluem produtos como: carne, aves domésticas, ovos, molhos, leite e produtos lácteos em geral (AKBAS et al., 2015). Podendo acometer tanto indivíduos saudáveis, como aqueles imunocomprometidos, frequentemente são vítimas desse microrganismo.

\subsubsection{Listeria monocytogenes}

\subsubsection{Etiologia}

O gênero Listeria consiste de uma série de espécies, que inclui L. monocytogenes, L.innocua, L. welshimeri, L. seeligeri, L. ivanovii, L. marthii, L. rocourtiae e L. grayi. Alguns são agentes patogênicos de mamíferos como: L. ivanovii e L. monocytogenes. Embora $L$. ivanovii parece ser predominantemente rara e causa doença em ruminantes, L. monocytogenes representa as espécies de Listeria mais comumente associada à doenças tanto em animais quanto em seres humanos (ORSI; BAKKER; WIEDMANN, 2011).

Listeria monocytogenes é um cocobacilo curto, Gram-positivo, não formador de endósporos (Figura 3), patogênico facultativo, que pode viver no solo e na vegetação em decomposição, mas uma vez que entra em um animal ou hospedeiro humano, pode causar doenças graves. Além disso é patógeno oportunista de origem alimentar, com características psicrotróficas, anaeróbico facultativo que pode está envolvido em vários surtos de doenças 
transmitidas por alimentos (MADIGAN et al., 2010). Uma delas é a listeriose, uma infecção alimentar gastrointestinal que pode levar à bacteremia e meningite. Afeta essencialmente mulheres grávidas, recém-nascidos, idosos e pacientes imunocomprometidos. Esse tipo de infecção pode se manifestar como uma gastroenterite leve ou completamente assintomáticos (BONSAGLIA et al., 2014; JAGLIC et al., 2014).

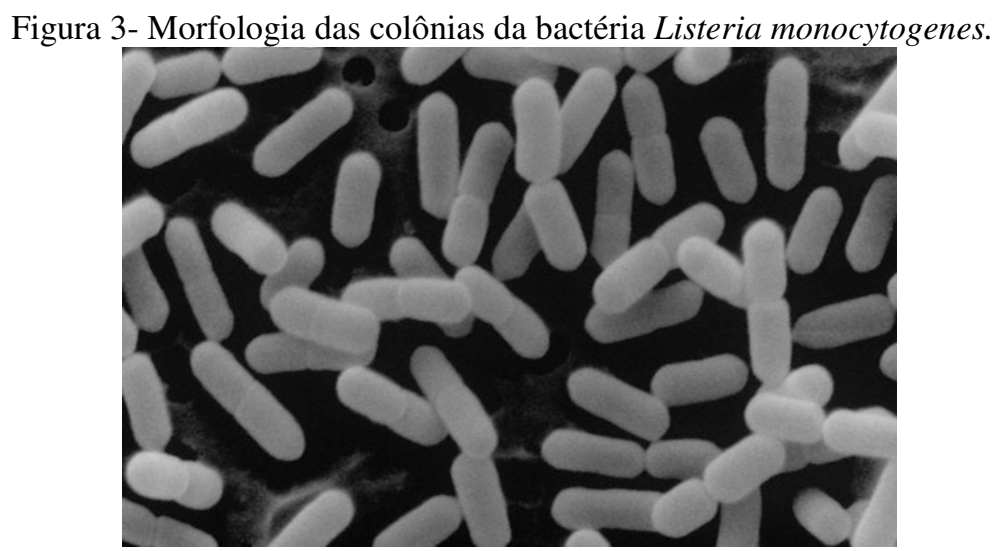

FONTE: Food and Drug Administration (FDA-EUA), 2013

\subsubsection{Epidemiologia}

A cada ano ocorrem cerca de 2.500 casos de listeriose humana clínica nos Estados Unidos (EUA) incluindo 500 mortes. No geral, a incidência de casos de listeriose tem sido relatada variar de 0,2 a 0,8 casos esporádicos em cada 100.000 pessoas por ano na Europa e nos EUA. Curiosamente na Europa, a incidência de listeriose parece ter aumentado desde o ano de 2000; em especial, a incidência entre aqueles maiores de 65 anos. Isso reforça o fato de que a incidência dessa doença ocorre principalmente em grupos de alto risco como: indivíduos imunocomprometidos, pacientes com HIV, idosos, crianças e mulheres grávidas, enquanto os indivíduos saudáveis raramente contraem listeriose invasiva (ORSI; BAKKER; WIEDMANN, 2011).

As manifestações clínicas mais graves de listeriose humana invasiva incluem septicemia, encefalite, meningite e aborto espontâneo. Já as subclínicas incluem uma doença semelhante à gripe leve, por vezes combinado com gastroenterite, bem como ocular e listeriose cutânea. A maioria (99 \%) das infecções provocadas por L. monocytogenes são de origem alimentar e portanto, envolve ingestão de alimentos contaminados (LOMONACO; NUCERA; FILIPELLO, 2015). 
A etapa inicial da colonização do tecido do hospedeiro é um processo rápido, e uma vez alojada no estômago a L. monocytogenes passa pela barreira intestinal e posteriormente as bactérias são distribuídas, através da linfa ou do sangue, para os nódulos linfáticos mesentéricos, o baço e o fígado. Estudos in vivo, realizados em ratos mostraram que a maioria das L. monocytogenes são removidas rapidamente da corrente sanguínea por macrófagos residentes no baço e fígado. Porém, uma parte das células que não são destruídas por macrófagos podem sobreviver e proliferar no fígado, aumentando em número em 2-5 dias. Após este período, as bactérias no fígado são geralmente eliminadas rapidamente nos animais com um sistema imunitário saudável. Nos indivíduos imunocomprometidos, a proliferação ilimitada das bactérias pode resultar na libertação de bactérias para a circulação. A partir do sistema circulatório, o conteúdo uterino e do sistema nervoso central pode ser invadido, que conduz a infecções fetais e aborto como encefalite e meningite (ORSI; BAKKER; WIEDMANN, 2011).

\subsubsection{Prevenção e Controle}

Esse microrganismo é único pela sua capacidade de crescer em temperatura de refrigeração, vasta gama de $\mathrm{pH}$, alta concentração de sal, portanto, apresenta uma ameaça às indústrias de alimentos que produzem produtos com vida útil prolongada e mantido a uma temperatura baixa (PAN et al., 2006). Além disso, suas células podem se fixar sobre uma grande variedade de superfícies, como: polipropileno, poliestireno, borracha, aço inoxidável, plástico e vidro (WEILER et al., 2013). Tem sido sugerido que a resistência apresentada por L. monocytogenes a agentes antimicrobianos ou sanitizantes em ambientes de processamento de alimentos, seja resultante da capacidade que suas células tem para formar biofilmes. Biofilmes de Listeria demonstraram ser muito mais resistentes ao stress e higienização que as suas células planctônicas (livres) (IBARRECHE; CASTELLANO; VIGNOLO, 2014).

Seu desenvolvimento pode ocorrer rapidamente em um substrato, e uma vez ligado, é difícil remoção. Sabe-se que algumas estirpes podem persistir por anos no ambiente de processamento de alimentos e foi também relatado que seus biofilmes são resistentes ao cloro, devido à presença de uma camada polimérica (SREY, et. al., 2014; WEILER et al., 2013). Os alimentos mais comumente envolvidos na contaminação por essa bactéria são: as carnes 
prontas para o consumo, queijos frescos, laticínios não pasteurizados e/ou leite pasteurizado inadequadamente (MADIGAN et al., 2010).

\subsection{Biofilmes}

Desde o início da microbiologia, os microrganismos têm sido caracterizados principalmente como células planctônicas, ou seja, células livres. Sua descrição foi feita com base nas propriedades morfológicas, fisiológicas e características de crescimento em meios de cultura nutricionalmente ricos (TORTORA et al., 2005). No entanto, na maioria dos ambientes naturais, os microrganismos são comumente encontrados em associação, próximos às superfícies e/ou interfaces ar-líquido na forma de agregados multicelulares envoltos por uma camada polimérica (BOWER; DAESCHEL, 1999; DONLAN, 2002). Essas comunidades dinâmicas e complexas são conhecidas como biofilmes. Este tipo de organização é extremamente vantajoso à todas as espécies de microrganismos por fornecer proteção contra adversidades como: desidratação, colonização por bacteriófagos e resistência a antimicrobianos e sanitizantes. Os biofilmes ocorrem em quase todos os ambientes úmidos onde o fluxo de nutriente disponível é suficiente e a superfície de ligação pode ser alcançada (ARAÚJO et al., 2013; HALL-STOODLEY et al., 2004).

Aproximadamente $97 \%$ da matriz do biofilme é formada por água, o que facilita os processos de difusão e mobilidade no seu interior. Além da água, essa matriz é composta por um complexo de polímeros secretados, nutrientes absorvidos, metabólitos, produtos de lise de células, partículas de materiais e detritos circundantes do ambiente (CAPPITELLI; POLO; VILLA, 2014). Portanto, além de peptídeoglicano, lipídios, fosfolipídios e outros componentes celulares, todas as principais classes de macromoléculas (proteínas, DNA, RNA) podem ser encontradas dentro de um biofilme (O'TOOLE et al., 2000).

\subsubsection{Formação dos biofilmes}

A formação de um biofilme permite um estilo de vida que é totalmente diferente do estado planctônico (FLEMMING; WINGENDER, 2010). Existem vários fatores relacionados ao estabelecimento de biofilmes, dentre eles os principais são: características físico-químicas da superfície e da célula, expressão de proteínas denominadas adesinas e fatores de virulência 
dos microrganismos, como produção da cápsula e fímbrias (TORTORA et al., 2005; DONLAN, 2002). Embora as interações precisas dos diferentes componentes em nível molecular ainda não sejam bem definidas (FLEMMING; WINGENDER, 2010).

O biofilme pode ser formado por populações constituídas a partir de uma única ou de múltiplas espécies (RENDUELES; GHIGO, 2012). Assim, quando o biofilme é composto por espécies diferentes, os produtos metabolizados por uma das espécies podem servir de suporte para o crescimento de outras. Em contra partida, a competição por nutrientes e o acúmulo de produtos tóxicos produzidos pelos microrganismos primários podem limitar a diversidade de espécies no interior do biofilme (CAIXETA, 2008; KIEREK-PEARSON; KARATN, 2005).

Em vista disso, muitas teorias têm sido propostas com relação à dinâmica de formação de um biofilme, as principais são: contato, adesão, formação de microcolônias, maturação e desprendimento (Figura 4), sendo as mesmas influenciadas pelo meio ambiente e características genéticas das bactérias envolvidas (BLACKLEDGE, et al., 2013; O'TOOLE et al., 2000).

Inicialmente as bactérias circulantes no meio-ambiente denominadas colonizadores primários, ao entrarem em contato com uma superfície, iniciam o processo de adesão reversível entre si e a superfície (Figura 4-1) (DONLAN, 2002). Uma vez que os microrganismos atingem proximidade a uma superfície, sua adesão é determinada por forças atrativas ou repulsivas geradas entre as duas superfícies como atrações eletrostáticas e van der Waals (Figura 4-2). Esta fixação é instável e reversível e, se o ambiente não oferecer condições favoráveis, como temperatura, condições nutricionais, dentre outras, as células podem se desprender da superfície (SREY et al., 2013). Porém quando as condições são favoráveis, as células aderidas passam a se desenvolver para um estágio irreversível (Figura 4-3). Nesta fase as forças de curto alcance envolvidas compreendem interações do tipo dipolo-dipolo, iônica, hidrogênio ou interações hidrofóbicas (CAPPITELLI; POLO; VILLA, 2014). 
Figura 4 - Representação do ciclo de formação de biofilme em superfície abiótica. Inicialmente a bactéria encontra-se na forma planctônica (livre) (1), posteriormente ocorre a adesão inicial (2), com crescimento e divisão ocorre adesões secundárias (3) e a formação da camada protetora constituindo o biofilme maduro (4) disperso por perdas de células (5) de acordo com as condições desfavoráveis a sua sobrevivência.

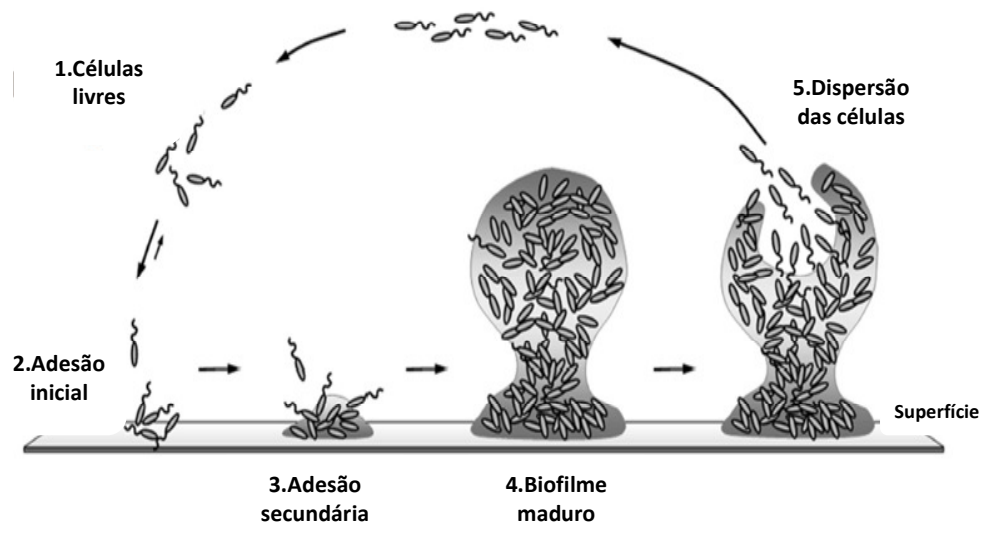

Fonte: Adaptado de O'TOOLE et al., 2000.

A fixação de células bacterianas em superfície também pode ser facilitada por estruturas de mobilidade (flagelos, fímbrias, pili), proteínas e exopolímeros produzidos pelas bactérias, originando microcolônias que sintetizam uma matriz polimérica extracelular (MPE), que passa a atuar como substrato para a adesão de outros microrganismos denominados colonizadores secundários (O'TOOLE et al., 2000; SREY et al., 2013). Estes colonizadores secundários podem se aderir diretamente aos primários, ou promover a formação de co-agregados com outros microrganismos (Figura 4-4) (SUTHERLAND, 2001). À medida que a população em sua proximidade aumenta, as bactérias formam microcolônias dispostas em pilares, compostas por uma camada com cerca de $10 \mu \mathrm{m}$ de espessura, podendo se estender em até $200 \mu \mathrm{m}$ acima da superfície. Essa forma de crescimento em pilares facilita a disponibilidade de nutrientes e também evita acúmulo de resíduos tóxicos constituindo um sistema circulatório simples (TORTORA et al., 2005). Uma vez formado, o biofilme pode permanecer aderido à superfície por um longo período ou então se desprender (Figura 4-5), servindo como uma fonte perpetuadora do ciclo ao liberar células livres para colonização de novos sítios (O’TOOLE et al., 2000).

\subsubsection{Matriz polimérica extracelular}

Como já descrito anteriormente os microrganismos geralmente não vivem como células individuais, em vez disso acumulam-se nas interfaces para formar agregados 
polimicrobianos, denominados de biofilmes. $\mathrm{Na}$ maioria dos biofilmes, os microrganismos representam menos de $10 \%$ da massa seca, enquanto que a matriz pode ser responsável por mais de $90 \%$. Esta matriz polimérica extracelular (MPE) pode ser definida como um material rico em diferentes tipos de biopolímeros, produzido pelos próprios microrganismos em que as células do biofilme são incorporadas (MORE et. al., 2014).

A MPE representa o alicerce da arquitetura tridimensional do biofilme, sendo responsável por várias funções. Dentre elas, a capacidade de imobilizar células do biofilme e mantê-las em proximidade permitindo comunicação célula-célula; retenção de enzimas extracelulares. Isso possibilita a digestão extracelular favorecendo a utilização de partículas como fontes de nutrientes e de energia (CAPPITELLI; POLO; VILLA, 2014; RENDUELES et al., 2012). Além disso, ela atua como um centro de reciclagem, mantendo todos os componentes de lise celular disponíveis. Isso inclui DNA, o que pode representar um reservatório constante para a transferência horizontal de genes. A matriz também protege os microrganismos contra a dessecação, contra a ação oxidante, e contra alguns antibióticos, biocidas e radiação ultravioleta (FLEMMING; WINGENDER, 2010). Sua composição química pode variar muito entre os biofilmes, isso inclui fatores como, os microrganismos, temperatura, disponibilidade de nutrientes, $\mathrm{pH}$ do meio entre outros (FLEMMING; WINGENDER, 2010; MORE et al., 2014). Porém sua constituição apresenta uma grande variedade de substâncias poliméricas extracelulares hidratadas, dentre elas:exopolissacarídeos, proteínas, lipídeos, ácidos nucléicos, e lipo-oligossacarídeos (FLEMMING; WINGENDER, 2010).

De acordo com a literatura, de um modo geral, as concentrações de MPE e as características químicas são dois fatores importantes que determinam o grau de adesão dos microrganismos. Com base no entendimento atual, existem basicamente três estratégias para reduzir a adesão, são elas: o controle da produção de biopolímeros, modificações das características do material polimérico e sua remoção do sistema (LIN et. al., 2014). O estudo dessas estratégias exige análises de diferentes componentes, além da caracterização química e funcional das diversas substâncias poliméricas extracelulares produzidas pelos microrganismos (MORE et al., 2014). 


\subsection{Biossurfatantes}

Biossurfatantes (BS) ou bioemulsificantes (BE) são compostos anfifílicos de origem biológica produzidos principalmente por microrganismos que incluem as bactérias, leveduras e fungos (GHARAEI-FATHABAD, 2011; MÜLLER et al., 2012). Eles possuem tanto uma região hidrofílica, polar ou não-polar (geralmente açúcares ou peptídeos), quanto uma região hidrofóbica (lipídios ou ácidos graxos).

Estas moléculas apresentam várias vantagens para a indústria em comparação aos tensoativos sintéticos, devido principalmente às características como: alta biodegradabilidade, aplicabilidade generalizada, grande eficácia em extremos de $\mathrm{pH}$ e temperatura e baixa toxicidade. Além disso, as propriedades de superfície e de redução da tensão interfacial destes compostos proporcionam excelente detergência, emulsificação e formação de espuma, tornando-os em um dos produtos mais versáteis em processos envolvendo as indústrias química, agrícola, cosmética, farmacêutica e de petróleo (BANAT; RIENZO; QUINN, 2014; GUDINÃ et al., 2013). O fato de serem altamente biodegradáveis combinado com a capacidade de solubilizar compostos hidrofóbicos pode explicar porque biossurfatantes também são reconhecidos como excelentes agentes para a biorremediação de ambientes contaminados (MARCHANT; BANAT, 2012).

Estas moléculas possuem diferentes estruturas químicas e propriedades de superfície, uma vez que podem ser produzidos por uma grande variedade de microrganismos em diferentes condições nutricionais e ambientais (BANAT et al., 2010). Com base na sua diversidade é razoável que apresentem diferentes aplicações específicas permitindo o uso potencial nos mais variados setores da indústria. Em meio aquoso, os biossurfatantes são capazes de formar diversas estruturas agregadas tais como micelas, vesículas esféricas ou irregulares, estruturas lamelares, entre outras. Eles se acumulam em interfaces apresentando diferentes polaridades, em especial óleo/água, ar/água, e atuam como agentes umectantes em superfícies sólidas (água/sólido). Esse processo dinâmico é baseado na habilidade dos biossurfatantes de reduzir a tensão superficial pelo remanejamento molecular, através do acúmulo de compostos insolúveis, influenciando as interações de hidrogênio e outras interações hidrofóbico-hidrofílicas, aumentando a área superficial destes (MARCHANT; BANAT, 2012). 
Os biossurfatantes podem ser intra, extracelulares ou constituintes da parede celular podendo desempenhar papéis críticos na sobrevivência dos microrganismos que os produzem. Estes compostos são capazes de romper as membranas celulares que levam à lise celular pelo aumento da permeabilidade da membrana e, consequentemente, perda de metabólitos. Estas mudanças na estrutura física da membrana ou modificações na conformação de proteínas alteram funções significativas da membrana que compõem o transporte e geração de energia. Em oposição a isso estas moléculas podem trazer benefícios às células tais como, facilitar o transporte de nutrientes, interferir nas interações entre microrganismos e mecanismos de quorum sensing (GUDINÃ et al., 2013).

\subsubsection{Classificação dos biossurfatantes}

A classificação dos biossurfatantes usa como base sua composição química e sua origem microbiana (DESAI; BANAT, 1997). Um resumo dos tipos de biossurfatantes e dos microrganismos produtores pode ser visualisados na Tabela 1. De maneira geral, eles podem ser divididos em dois grandes grupos: biossurfatantes de alta massa molecular e de baixa massa molecular (RON; ROSENBERG, 2001). Os de alta massa molecular incluem um grande número de compostos poliméricos extracelulares constituídos de polissacarídeos, proteínas, lipopolissacarídeos, lipoproteínas ou misturas complexas desses biopolímeros (NITSCHKE; PASTORE, 2002).

Tabela 1- Principais classes de biosurfatantes e microrganismos envolvidos.

\begin{tabular}{|c|c|}
\hline Tipos de biossurfactantes & Microrganismos \\
\hline $\begin{array}{l}\text { Glicolipídios } \\
\text {-Ramnolipídios } \\
\text {-Soforolipídios } \\
\text {-Trehalolipídios }\end{array}$ & $\begin{array}{l}\text { Pseudomonas aeruginosa } \\
\text { Torulopis bombicola } \\
\text { Mycobacterium sp. }\end{array}$ \\
\hline $\begin{array}{l}\text { Lipopeptídios e lipoproteínas } \\
\text {-Peptídio-lipídio } \\
\text {-Viscosina } \\
\text {-Surfactina }\end{array}$ & $\begin{array}{l}\text { Bacillus licheniformis } \\
\text { Pseudomonas fluorescens } \\
\text { Bacillus subtilis }\end{array}$ \\
\hline $\begin{array}{l}\text { Ácidos graxos, lipídios neutros e } \\
\text { fosfolipídios } \\
\text {-Ácidos graxos } \\
\text {-Lipídios neutros } \\
\text {-Fosfoliídios }\end{array}$ & $\begin{array}{l}\text { Corynebacterium lepus } \\
\text { Nocardia erythropolis } \\
\text { Thiobacillus thiooxidans }\end{array}$ \\
\hline $\begin{array}{l}\text { Surfactantes poliméricos } \\
\text {-Emulsan } \\
\text {-Biodispersan } \\
\text {-Liposan } \\
\text {-Carboidrato-lipídio-proteína } \\
\text {-Manana-lipídio-proteína }\end{array}$ & $\begin{array}{l}\text { Acinetobacter calcoaceticus } \\
\text { Acinetobacter calcoaceticus } \\
\text { Candida lipolytica } \\
\text { Pseudomonas fluorescens } \\
\text { Candida tropicalis }\end{array}$ \\
\hline $\begin{array}{l}\text { Surfactantes particulados } \\
\text {-Vesículas } \\
\text {-Células }\end{array}$ & $\begin{array}{l}\text { Acinetobacter calcoaceticus } \\
\text { Várias bactérias }\end{array}$ \\
\hline
\end{tabular}


Os biossurfatantes mais bem estudados representantes dessa classe são Biodispersan, Emulsan e Liposan, sendo todos complexos de polissacarídeos e proteínas. O segundo grupo inclui, além dos ácidos graxos, fosfolipídeos e lipídeos neutros, os lipopeptídeos e os glicolipídeos. Os lipopeptídeos mais pesquisados incluem a surfactina, estreptofactina e polimixinas, enquanto que os glicolipídeos mais estudados são os trealolipídeos, soforolipídeos e os ramnolipídeos (DESAI; BANAT, 1997; RON; ROSENBERG, 2001).

\subsubsection{Ramnolipídeos: estrutura, propriedades e aplicações}

Os ramnolipídeos (RLs) são glicolipídeos extracelulares produzidos principalmente por Pseudomonas aeruginosa formados em sua maioria por uma ou duas unidades de Lramnose ligadas a um ou dois $\beta$-hidroxi ácidos graxos (MÜLLER et al, 2012) sendo classificados como mono-ramnolipídeo e di-ramnolipídeo (Figura 5). Estes compostos representam uma das classes de biossurfatantes mais importantes pois apresentam propriedades que possibilitam inúmeras aplicações, sendo considerados alvos adequados para uso em diversas áreas da indústria (IRFAN-MAQSOOD; SEDDIQ-SHAMS, 2014).

Figura 5- Estrutura química do (A) mono-ramnolipídeo e do (B) di-ramnolipídeo, com m, n= 6-18.

A

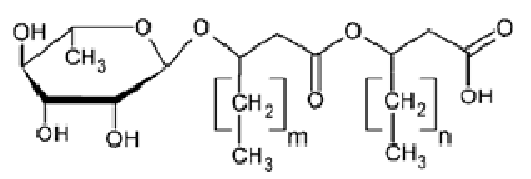

B

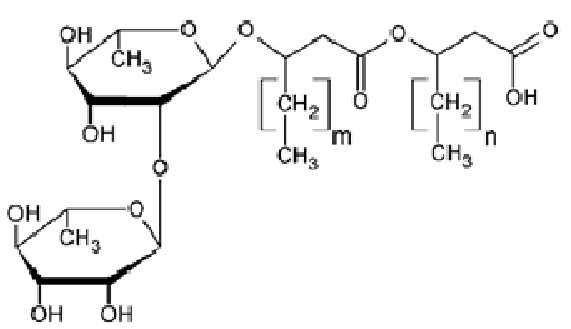

Fonte: MÜLLER et al, 2012.

Os ramnolipídeos apresentam várias propriedades importantes, tais como: fácil degradabilidade além de serem atóxicos e não mutagênicos. Aqueles produzidos por $P$. aeruginosa podem diminuir a tensão superficial da água de $72 \mathrm{mN} \mathrm{m}^{-1}$ para $25-30 \mathrm{mN} \mathrm{m}^{-1}$, e a tensão interfacial de água/ hexadecano para valores menores que $1 \mathrm{mN} \mathrm{m}^{-1}$ (MÜLLER et al, 2012). Outra vantagem é sua capacidade de formar emulsões estáveis em intervalos variando de meses a anos. Apresentam uma boa atividade de superfície e podem ser produzidos com rendimentos relativamente elevados em tempos curtos em contraste a outros biossurfatantes (HENKEL et al., 2012). 
Apesar de todas estas características seus custos elevados devido ao processo de purificação podem dificultar sua inserção no mercado, assim como sua variação estrutural que dificulta a integração em todos os campos de aplicação. Como outros biossurfatantes, os ramnolipídeos podem ser produzidos por diversas espécies de bactérias como Pseudomonas e Burkholderia, sendo $P$. aeruginosa a espécie de maior destaque, com rendimentos em torno de $100 \mathrm{~g} \mathrm{~L}^{-1}$ (TORIBO; ESCALANTE; SOBERÓN-CHÁVEZ, 2010). O preço de mercado atual dos ramnolipídeos comerciais (95\% de pureza) é U\$ 227/10 mg (Sigma-Aldrich) e U\$ 200/10 mg (AGAE Technologies, USA). Para diminuir esses problemas, um grande esforço baseado em engenharia genética e biotecnológica, visando otimizar e ampliar a produção de ramnolipídeos tem sido realizados (HENKEL et al, 2012); pois juntamente com soforolipídeos, os ramnolipídeos são os únicos aprovados pela Agência de Proteção Ambiental dos Estados Unidos para uso em produtos alimentares, cosméticos e farmacêuticos (TORIBO; ESCALANTE; SOBERÓN-CHÁVEZ, 2010).

As aplicações dos ramnolipídeos incluem emulsificação, detergência, formação de espuma, solubilização, biorremediação entre outras (REIS et al., 2011). Além disso, podem ser utilizados no controle de fungos, algas, vírus e bactérias além de apresentar atividade antiadesivas e dispersão de biofilmes (Figura 6). Estudos realizados por Zeraik e Nitschke (2012) mostraram que os ramnolipídeos inibiram a adesão de $S$. aureus, L. monocytogenes e $M$. luteus em superfície de poliestireno sob diferentes condições de temperatura. Esse comportamento foi promovido principalmente pela redução da hidrofobicidade da superfície submetida ao condicionamento com o RL.

Figura 6- Aplicação de ramnolipídeo no controle de microrganismos. (a) Atividade anti-adesiva, (b) Atividade antimicrobiana e (c) Remoção do biofilme pré-existente em superfície biótica ou abiótica.

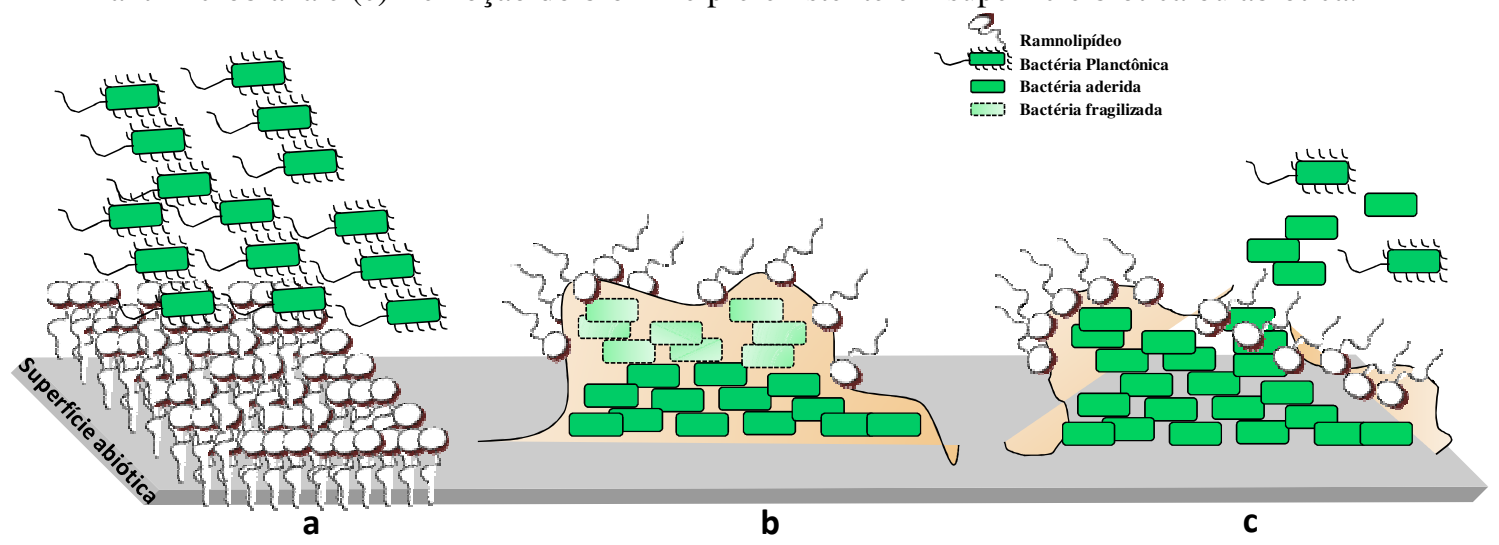

Fonte: Adaptado de NITSCHKE; SILVA, 2016. 
Além dessas propriedades citadas acima, os ramnolipídeos desempenham um papel importante na regulação e desenvolvimento de biofilmes mostrando uma influência ambivalente dependendo da ação espaço-temporal. Provavelmente, o modelo mais bem estudado para investigar esta interação é o patógeno oportunista $P$. aeruginosa (NICKZAD; DÉZIEL, 2013). Nesta bactéria os ramnolipídeos são produzidos naturalmente, e são encontrados como misturas de diferentes congêneres. Estas moléculas atuam como fator de virulência e mediam a dispersão ativa de células do biofilme, ajudando na colonização de novos sítios e nichos de ligação. Além disso, eles agem como principais agentes protetores da $P$. aeruginosa contra fagócitos. Os ramnolipídeos podem apresentar atividade anti-adesiva (Figura 6-a) contra algumas bactérias e fungos, modificando as cargas superficiais de diferentes superfícies abióticas como: polietileno, poliestireno, aço-inoxidável. Atuam também como agente antimicrobiano (Figura 6-b), em um amplo espectro de bactérias Grampositivas (Bacillus pumilus, L.monocytogenes, e S. aureus) e Gram-negativas (S. enteritidis) e fungos (Yarrowia lipolytica) (KIM et al., 2015). E atividade de remoção de biofilmes já estabelecidos (Figura 6-c) (GOMES, 2011).

Em estudo realizado recentemente por Kim e colaboradores (2015) foram investigadas as interações físico-químicas entre o ramnolipídeo e o biofilme $P$. aeruginosa. Os resultados mostraram que o uso da $300 \mu \mathrm{g} \mathrm{mL}^{-1}$ de ramnolipídeo (próximo à CMC: $240 \mu \mathrm{g} \mathrm{mL}^{-1}$ ), apresentou grande potencial de redução de biofilme além de interagir seletivamente com diferentes proteínas presentes no material polimérico.

A evidência acima sugere que os ramnolipídeos podem ser explorados no controle de biofilme $P$. aeruginosa, como também outros microrganismos. No entanto, os mecanismos exatos pelos quais os biofilmes pré-formados são rompidos ainda não estão bem elucidados. 


\section{OBJETIVOS}

\subsection{Objetivo geral}

Estudar a potencialidade de aplicação dos ramnolipídeos no controle e remoção de biofilmes formados por bactérias patogênicas de importância alimentar.

\subsection{Objetivos específicos}

-Estabelecer a cinética de adesão e formação de biofilmes de culturas de Staphylococcus aureus, Escherichia coli, Listeria monocytogenes sobre o poliestireno.

-Verificar os efeitos da concentração de ramnolipídeo e da temperatura na remoção de biofilmes de Staphylococcus aureus, Escherichia coli, Listeria monocytogenes formados em superfícies de poliestireno.

-Comparar a remoção dos biofilmes formados em meio de cultura comercial e em leite para cada microrganismo.

-Comparar a composição química da matriz polimérica extracelular (MPE) dos biofilmes formados pelas diferentes bactérias.

-Relacionar a composição da MPE com a atividade do ramnolipídeo.

-Avaliar o efeito dos ramnolipídeos na hidrofobicidade da superfície dos biofilmes.

-Realizar estudos físico-químicos através das técnicas de espalhamento dinâmico de luz (DLS) e espalhamento de raio-X a baixo ângulo para entender o comportamento dos ramnolipídeos em diferentes concentrações e temperaturas. 


\section{MATERIAIS E MÉTODOS}

O presente trabalho foi desenvolvido no laboratório de Biotecnologia Microbiana, do Departamento de Físico-Química, pertencente ao Instituto de Química de São Carlos da Universidade de São Paulo (USP) de acordo com o fluxograma apresentado na Figura 7. Também foram utilizadas as instalações do Laboratório de Biofísica Molecualar- IFSC e IQSC/USP, Laboratório de Bioquímica- FCFRP/USP, Grupo de Polímeros "Prof. Bernhard Gross"- IFSC/USP, Laboratório de Processos Biológicos pertencente ao Departamento de Hidráulica e Saneamento da EESC/USP e o Laboratório Nacional de Luz Síncrotron- LNLS.

Figura 7- Fluxograma das etapas de execução deste trabalho.

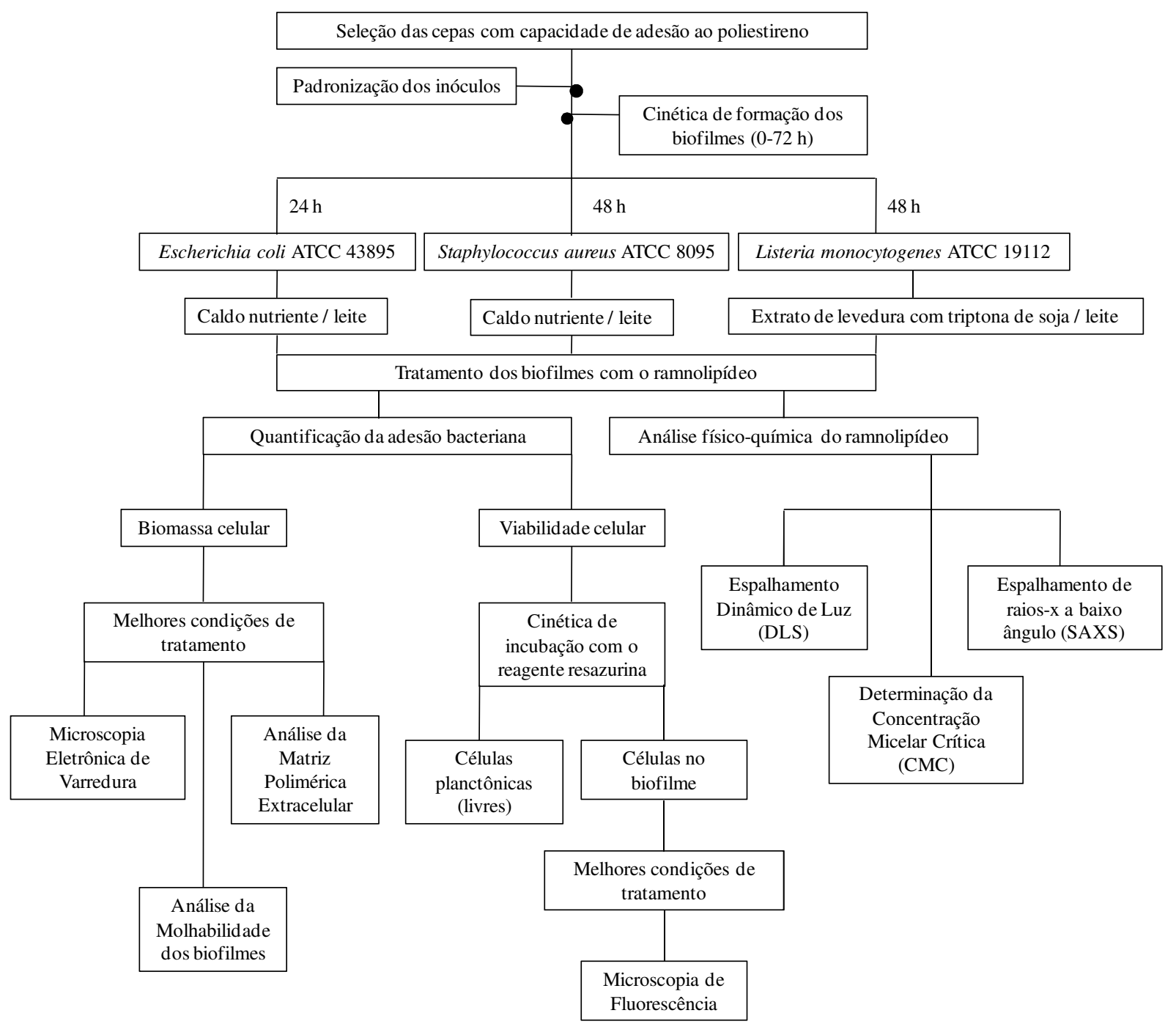




\subsection{Microrganismos}

As cepas selecionadas para o estudo foram Staphylococcus aureus ATCC 8095, Escherichia coli (EHEC) ATCC 43895 e Listeria monocytogenes ATCC 19112 relacionadas a contaminação alimentar. De acordo com a FIOCRUZ (2005) esses microrganismos apresentam nível de biosegurança 2, pois são capazes de causar doenças em seres humanos ou em animais de laboratório sem apresentar risco grave aos trabalhadores, comunidade ou ambiente. Além disso, não são agentes transmissíveis pelo ar e existe tratamento efetivo e medidas preventivas disponíveis.

\subsection{Biossurfatante}

O biossurfatante utilizado neste trabalho foi o ramnolipídeo comercial com $99 \%$ de pureza produzido por P. aeruginosa e fornecido pela empresa Rhamnolipid Inc. em solução aquosa de $25 \%$. Este composto consiste na mistura de dois homólogos majoritários: mono (R1) e di-ramnolipídeo (R2), cujo as fórmulas moleculares e massas molares são $\mathrm{C}_{26} \mathrm{H}_{48} \mathrm{O}_{9}$ $\left(504 \mathrm{~g} \mathrm{~mol}^{-1}\right)$ e $_{32} \mathrm{H}_{58} \mathrm{O}_{13}\left(650 \mathrm{~g} \mathrm{~mol}^{-1}\right)$, respectivamente.

\subsubsection{Preparo das soluções de ramnolipídeo}

O ramnolipídeo foi diluído em água destilada com $\mathrm{pH} 7,0 \pm 0,2$. E em seguida foi esterilizado por filtração em filtro com poros de $0,22 \mu \mathrm{m}$ (Sartorius) mantendo-se refrigerado até o momento do uso. As concentrações utilizadas foram $0,05 \%, 0,1 \%, 0,25 \%, 0,5 \%, 1 \%$ e $2 \% \mathrm{v} / \mathrm{v}$.

\subsection{Preparo dos meios de cultura}

Utilizou-se dois meios de cultura para crescimento bacteriano em placas de Petri, o Extrato de levedura com triptona de soja e ágar- TSYEA (Himedia) e o Caldo nutriente- CN (Himedia). A composição dos meios está descrita na Tabela 2, onde o meio TSYEA foi preparado conforme o fabricante $(40 \mathrm{~g}$ para $1.000 \mathrm{~mL})$ e o $\mathrm{CN}(13 \mathrm{~g}$ para $1.000 \mathrm{~mL})$, dissolvidos em água destilada e submetidos à esterilização em autoclave por 20 min à $121{ }^{\circ} \mathrm{C}$. 
Tabela 2- Meios de cultura utilizados para crescimento bacteriano em placas de Petri.

\begin{tabular}{|c|c|c|c|c|}
\hline Microrganismos & Meios de cultivo & Composição & $\left(\mathrm{g} \mathrm{L}^{-1}\right)$ & $\mathrm{pH}$ final $\left(25^{\circ} \mathrm{C}\right)$ \\
\hline Staphylococcus aureus & $\begin{array}{l}\text { Caldo nutriente } \\
\text { (CN) }\end{array}$ & $\begin{array}{c}\text { Digestão enzimática de gelatina; } \\
\text { Extrato de carne; } \\
\text { Extrato de levedura; } \\
\text { Cloreto de sódio; } \\
\text { Ágar }\end{array}$ & $\begin{array}{c}5 \\
1,5 \\
1,5 \\
5 \\
20\end{array}$ & $7,4 \pm 0,2$ \\
\hline Listeria monocytogenes & $\begin{array}{c}\text { Extrato de } \\
\text { levedura com } \\
\text { triptona de soja e } \\
\text { ágar (TSYEA) }\end{array}$ & $\begin{array}{c}\text { Digestão enzimática de caseína; } \\
\text { Digestão enzimática de farinha de soja; } \\
\text { Cloreto de sódio } \\
\text { Dipotássio de fósforo; } \\
\text { Dextrose } \\
\text { Ágar }\end{array}$ & $\begin{array}{c}17 \\
3 \\
5 \\
2,5 \\
2,5 \\
20\end{array}$ & $7,3 \pm 0,2$ \\
\hline
\end{tabular}

Para os meios de cultura líquido, utilizados na formação dos biofilmes, utilizou-se o TSYE e o caldo nutriente com a mesma composição descrita anteriormente, porém sem adição de ágar bacteriológico. Também foi utilizado como meio de crescimento bacteriano, o leite em pó desnatado (Elegê) reconstituído na concentração final de $10 \%$ (p/v) em água destilada, com pH final de $6,5 \pm 0,2$ à $25^{\circ} \mathrm{C}$. Sendo posteriormente esterilizado em autoclave a $121{ }^{\circ} \mathrm{C}$ por $10 \mathrm{~min}$.

\subsection{Preparo e manutenção dos estoques dos microrganismos de estudo}

O preparo e manutenção das culturas para a execução deste trabalho foram realizados à partir de estoques iniciais fornecidos pela FIOCRUZ e mantidos no Laboratório de Biotecnologia Microbiana a $-80^{\circ} \mathrm{C}$. Dessa forma, as culturas dos microrganismos escolhidos foram inoculadas com auxílio de alça de inoculação em placas contendo TSYEA/ CN (meios ótimos de crescimento para cada bactéria) e incubadas em estufa bacteriológica a $37{ }^{\circ} \mathrm{C}$ por $24 \mathrm{~h}$. Decorrido esse período adicionou-se em cada placa $5 \mathrm{~mL}$ de TSYE/ CN contendo $20 \%$ de glicerol. Após a remoção das colônias com auxílio de alça de inoculação, $800 \mu \mathrm{L}$ das suspensões bacterianas foram adicionadas à tudos criogênicos, os quais foram mantidos à - 20 ${ }^{\circ} \mathrm{C}$ para uso contínuo durante toda a execução deste trabalho.

\subsection{Padronização dos inóculos bacterianos}

Os experimentos para a padronização dos inóculos foram realizados a partir das culturas bacterianas mantidas em estoque à - $20{ }^{\circ} \mathrm{C}$, como mencionado no item 4.4. $\mathrm{O}$ procedimento de padronização consistiu em inocular inicialmente as culturas em placas 
contendo TSYEA/ CN, incubadas em estufa bacteriológica a $37{ }^{\circ} \mathrm{C}$ por $24 \mathrm{~h}$. Após esse período de incubação, adicionou-se $5 \mathrm{~mL}$ da solução salina $(\mathrm{NaCl}$ 0,86 \%) em placa de Petri e removeu-se a biomassa com auxílio de alça de inoculação. Em seguida transferiu-se o conteúdo para microtubos de $2 \mathrm{~mL}$ e centrifugou-se à $10.000 \mathrm{rpm}$ por $10 \mathrm{~min}$. Após a centrifugação descartou-se o sobrenadante e resuspendeu-se o sedimento celular em aproximadamente $2 \mathrm{~mL}$ de solução salina. Posteriormente o número de células viáveis foi ajustado com a medida de densidade óptica (DO) em espectrofotômetro UV-VIS (Thermo Scientific) a $610 \mathrm{~nm}$ para um valor entre 0,80 e 0,90, visando padronizar o inóculo para os ensaios de formação de biofilmes.

Após o ajuste da DO adicionou-se $1 \mathrm{~mL}$ deste inóculo em tubo de ensaio contendo 9 $\mathrm{mL}$ de solução salina, previamente esterilizada. A suspensão bacteriana obtida foi submetida a diluições seriadas de $10^{-1}$ a $10^{-9}$, como é pode-se observar na Figura 8. Em seguida gotas de $15 \mu \mathrm{L}$ de cada diluição foram depositadas em placas contendo meio e incubadas a $37{ }^{\circ} \mathrm{C}$ por $24 \mathrm{~h}$. A contagem de colônias foi realizada apenas nas gotas que possuíam de 5 à 50 unidades formadoras de colônias (UFC) (MILES; MISRA, 1938). O número de células viáveis foi determinado pela média do número de colônias, multiplicado pela diluição, obtendo-se assim o número de UFC por mililitro de solução. A concentração celular foi ajustada para $10{ }^{9}$ UFC $\mathrm{mL}^{-1}$ estabelecendo-se a DO correspondente a este valor para proceder com os testes de formação de biofilmes. Este procedimento foi realizado com cada bactéria de estudo.

Figura 8- Esquema ilustrativo do método de diluições seriadas seguido de contagem em gotas em placas de Petri.

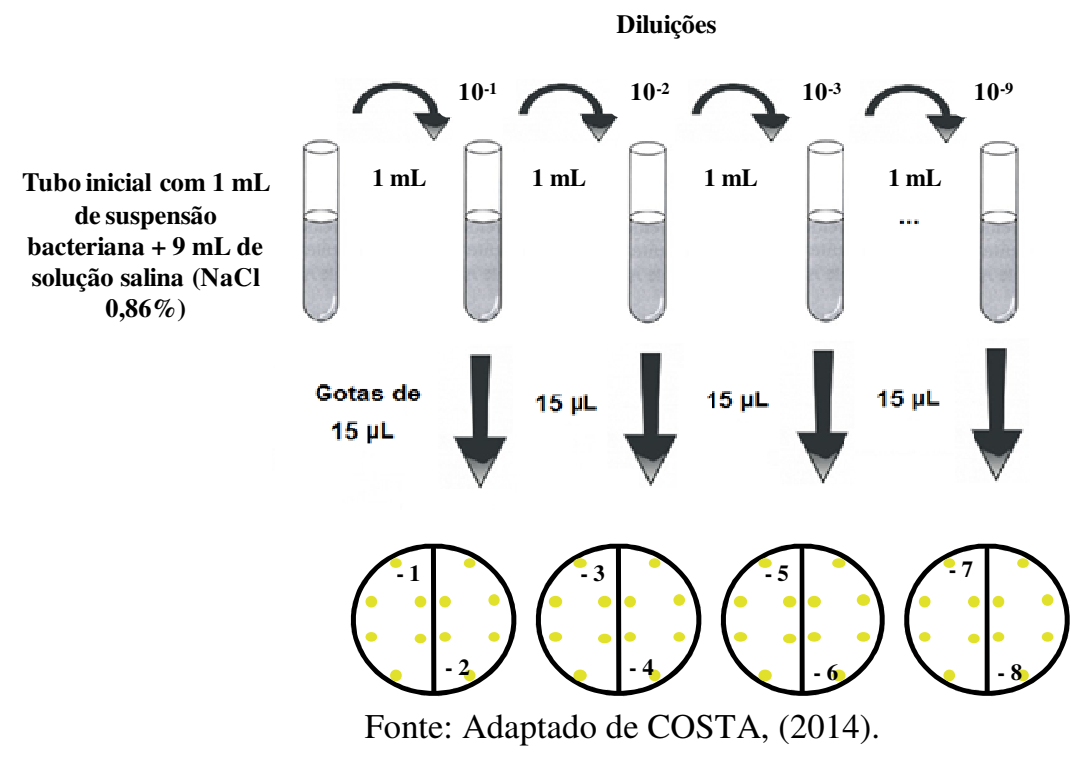




\subsection{Ensaio de formação dos biofilmes em poliestireno}

Para avaliar o crescimento dos biofilmes de cada uma das bactérias em diferentes tempos, alíquotas de $20 \mu \mathrm{L}$ de suspensão bacteriana $\left(10^{9} \mathrm{UFC} \mathrm{mL}^{-1}\right)$ foram inoculadas em microplaca de poliestireno de 96 cavidades contendo $180 \mu \mathrm{L}$ do meio de interesse (TSYE/caldo nutriente/ leite). As microplacas foram incubadas a $37{ }^{\circ} \mathrm{C}$ por um período de 0 $72 \mathrm{~h}$ em estufa bacteriológica, devidamente vedadas com plástico filme para evitar a evaporação e posteriormente a biomassa celular foi quantificada com cristal violeta $0,5 \%$ (Synth), para determinar o tempo de crescimento em que houve maior formação de biofilme, conforme metodologia descrita no item 4.8.1.

\subsection{Tratamento dos biofilmes com ramnolipídeo: efeito da temperatura, concentração e meio de crescimento}

Após o crescimento dos biofilmes como descrito acima, o meio de cultura foi removido e realizou-se lavagem $(2 \mathrm{x})$ das cavidades com água destilada. Em seguida foi adicionado $200 \mu \mathrm{L}$ de solução de ramnolipídeo em diferentes concentrações $(0,05 \%, 0,1 \%$, $0,25 \%, 0,5 \%, 1 \%$ e $2 \%$ ) deixando-se em contato por $2 \mathrm{~h}$ de forma estática. Esse tratamento foi realizado nas temperaturas de $4{ }^{\circ} \mathrm{C}, 25{ }^{\circ} \mathrm{C}$ e $37^{\circ} \mathrm{C}$ visando identificar em qual temperatura ocorre a maior remoção do biofilme. Esses mesmos procedimentos foram realizados para os biofilmes de cada bactéria de estudo nos meios de cultivo TSYE, caldo nutriente e leite.

\subsection{Quantificação dos biofilmes}

\subsubsection{Biomassa celular}

Após o estabelecimento dos biofilmes como descritos no item 4.6 foi realizada a quantificação da biomassa celular. Para esse procedimento as cavidades das placas de poliestireno foram lavadas com água destilada esterilizada (2x). O biofilme aderido foi fixado com $200 \mu \mathrm{L}$ de álcool metílico 99,9\% (Qhemis) por 15 min e a adesão bacteriana visualizada após 15 min de coloração com $200 \mu \mathrm{L}$ de solução aquosa de cristal violeta 0,5 \% (Synth). Após lavagem com água destilada o corante foi extraído com $200 \mu \mathrm{L}$ com ácido acético 
glacial $33 \%$ (Synth) e após 15 min procedeu-se a leitura da densidade óptica da solução a 630 nm em leitora automática de microplacas Enspire (PerkinElmer). A quantidade de biofilme removido foi comparada com o controle tratado com água destilada (MIRELES II, 2001). Esse controle serviu de referência (sendo considerado $100 \%$ de biofilme não removido), em comparação com os tratamentos com o ramnolipídeo.

\subsubsection{Viabilidade celular}

Para aquantificação das células viáveis presentes no biofilme antes e após o tratamento com o ramnolipídeo foi utilizado o ensaio do corante redox resazurina (indicador da atividade metabólica), segundo a metodologia descrita por Sandberg et al., (2009). A forma oxidada da resazurina é azul (não fluorescente/célula não viável) e a forma reduzida é rósea (fluorescente/célula viável), esta redução é proporcional ao número de células metabolicamente ativas (RIBEIRO et al., 2004).

Inicialmente realizou-se uma cinética de tempo de incubação do reagente à $25^{\circ} \mathrm{C}$, em células livres e no biofilme para comparação e padronização da metodologia para cada bactéria. Após o estabelecimento do biofilme como dito anteriormente, os mesmos foram submetidos à lavagem com água destilada para remoção de células não aderidas e adicionado $190 \mu \mathrm{L}$ de água destilada e $10 \mu \mathrm{L}$ de solução de resazurina $\left(0,1 \mathrm{~g} \mathrm{~L}^{-1}\right)$. Incubou-se a placa no escuro à temperatura ambiente. A fluorescência foi medida em comprimentos de onda ( $\lambda_{\text {excitação: }} 570 \mathrm{~nm}$ e $\lambda_{\text {emissão: }} 590 \mathrm{~nm}$ ) em leitora de microplacas comparando-se com o controle (sem tratamento) (RIBEIRO et al., 2004). Esse controle serviu de referência (sendo considerado $100 \%$ de biofilme), em comparação com os tratamentos com o ramnolipídeo.

\subsection{Avaliação da molhabilidade dos biofilmes}

O fenômeno de molhabilidade está associado à interação de um líquido com uma superfície, ou seja, o quanto uma gota líquida se espalha sobre uma superfície molhando-a (DALTIN, 2011). Essa interação pode levar ao espalhamento do líquido sobre a superfície, penetração do líquido nos poros do meio ou ainda o seu escoamento sobre essa superfície sob a forma de gotas. Na Figura 9 está representada uma gota de água em contato com uma superfície sólida rodeada por gás. Quanto menor o ângulo de contato $(\theta)$, maior a 
molhabilidade, isto é, mais o líquido molha a superfície sólida em contato. A molhabilidade é então determinada a partir do ângulo de contato de equilíbrio.

Figura 9- Medidas do ângulo de contato entre uma gota de água e uma superfície sólida mostrando o grau de molhabilidade referente à cada perfil de gota.

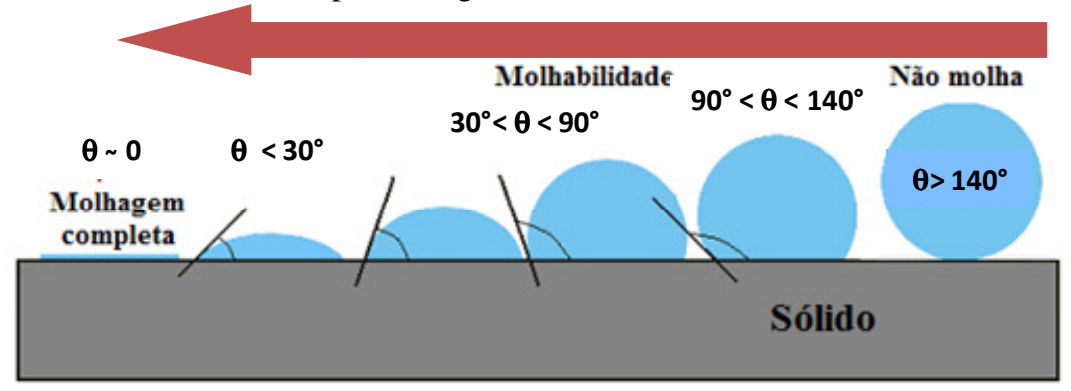

Fonte: Adaptado de http://www.alfaconnection.pro.br/

O ângulo de contato tem sido comumente usado para representar a molhabilidade da superfície e suas medidas de baseiam no ângulo de Young, onde o mesmo é determinado em termos das tensões superficiais entre as diferentes interfaces que formam o sistema (LUZ; RIBEIRO; PANDOLFELLI; 2008), segundo a Equação de Young abaixo:

$$
\cos \theta_{Y}=\frac{\gamma_{\mathrm{SG}}-\gamma_{\mathrm{SL}}}{\gamma_{\mathrm{LG}}} \quad \text { Equação } 1
$$

Onde $\gamma_{\text {sG }}$ é a tensão superficial por unidade de área entre as interfaces sólida e gasosa, $\gamma_{\mathrm{SL}}$ é a tensão superficial por unidade de área entre as interfaces sólida e líquida e $\gamma_{\mathrm{LG}}$ é a tensão superficial entre a interface líquida e gasosa (LUZ; RIBEIRO; PANDOLFELLI; 2008).

Neste trabalho, a molhabilidade da superfície de todas as amostras foi avaliada por meio de medidas de ângulo de contato a fim de avaliar a hidrofobicidade-hidroficilicidade da superfície tratada e não-tratada com o ramnolipídeo. As medidas foram feitas ao ar e à temperatura ambiente usando o equipamento denominado de goniômetro CAM200 (KSV), sendo que posteriormente foram captadas imagens da gota por uma câmara digital e os ângulos de contato foram medidos com recurso de um programa existente no mesmo equipamento. Esse programa faz o ajuste do perfil da gota tendo em conta a equação de 
Young (Equação 1) e traça uma tangente ao perfil da mesma, a partir da qual se determina o ângulo de contato entre o líquido e o substrato.

Dessa forma, o líquido utilizado foi a água ultrapura através do método estático ou da gota séssil, utilizando gotas de $3 \mu \mathrm{L}$ controladas por seringa graduada de $1 \mathrm{~mL}$, em temperatura ambiente. Foram utilizados cupons de poliestireno, com dimensões de 2,4 x 7,6 $\mathrm{cm}$, como superfície para o crescimento dos biofilmes. Todos previamente higienizados por imersão em etanol 99 \% (v/v), seguida de banho ultrasônico por 10 min, lavados com água destilada, submersas em solução aquosa $2 \%$ de detergente comercial, e submetida a limpeza em lavadora ultrasônica por mais $10 \mathrm{~min}$. Posteriormente, os cupons foram esterilizados por radiação ultravioleta em fluxo laminar por no mínimo $1 \mathrm{~h}$.

Após a devida esterilização os cupons foram utilizados para o crescimento dos biofilmes com as bactérias de estudo em tempo pré-determinado anteriormente. Em seguida foram mergulhados em soluções de ramnolipídeo ou água (controle) por imersão por $2 \mathrm{~h}$ em temperaturas específicas. Após o período de incubação, os cupons foram lavados com água e deixados para secar em temperatura ambiente e analisados pela técnica da gota séssil. Para manter a umidade das amostras, os cupons de poliestireno contendo os biofilmes foram transferidos para placas de Petri contendo ágar $1 \%(\mathrm{p} / \mathrm{v})$ com $10 \%$ de glicerol (v/v), por pelo menos $3 \mathrm{~h}$, antes de iniciar as medidas de ângulo de contato.

\subsection{Análise bioquímica da matriz polimérica extracelular}

\subsubsection{Obtenção do peso seco da matriz do biofilme}

Para o crescimento dos biofilmes foram utilizados cupons de poliestireno, com dimensões de 2,4 x 7,6 cm. Todos previamente higienizados como já mencionado no item 4.9. Após a devida esterilização os cupons foram utilizados para o crescimento dos biofilmes com as bactérias de estudo, conforme já mencionado no item 4.9. Em seguida foram mergulhados em soluções de ramnolipídeo e/ou água (controle) por imersão por um período de $2 \mathrm{~h}$ em temperaturas pré-estabelecidas (condições que apresentaram maior remoção dos biofilmes). Após o período de incubação, os cupons foram lavados com água destilada esterilizada (2x) 
para remoção de células não aderidas, e do excesso de ramnolipídeo e armazenados em solução salina $(0,86 \%)$.

Em seguida todas as amostras (controles e tratamentos) de cada bactéria foram submetidas a banho ultrasônico por 5 min para o desprendimento da matriz polimérica extracelular. O sobrenadante foi então agitado para homogeneização e posteriormente submetido a secagem em liofilizador SpeedVac SC200 (Savant), por um período de aproximadamente $12 \mathrm{~h}$, ou até alcançar peso constante. Esse procedimento foi realizado em triplicata sendo três experimentos independentes para cada bactéria em estudo. Após a preparação das amostras liofilizadas, estas foram utilizadas para as análises de carboidratos, proteínas e DNA extracelular.

\subsubsection{Quantificação de carboidratos totais}

A dosagem de carboidratos foi realizada de acordo com a método fenol-sulfúrico (DUBOIS et al, 1956) a partir da amostra liofilizada obtida no item 4.10.1 utilizando glicose para a curva padrão. Brevemente, foi adicionado $0,5 \mathrm{~mL}$ de amostra em um tubo de ensaio (15 $\mathrm{mL}$ ), em seguida foi adicionado 0,5 $\mathrm{mL}$ de fenol $\left(50 \mathrm{~g} \mathrm{~L}^{-1}\right)$ e imediatamente $2,5 \mathrm{~mL}$ de ácido sulfúrico $(97 \%)$. A solução foi então homogeneizada utilizando agitador tipo vortex e deixada em descanso por $15 \mathrm{~min}$ em temperatura ambiente. A leitura da absorbância foi realizada em $490 \mathrm{~nm}$ em leitor de microplacas em espectrofotômetro Cary 50 (Varian), utilizando tampão fosfato como branco preparado similarmente a amostra pura ou diluída. A quantidade de carboidratos pode então ser quantificada em $\mu \mathrm{g}_{\text {carboidratos }} / \mathrm{mg}_{\text {biofilme }}$.

\subsubsection{Quantificação de proteínas totais}

A dosagem de proteínas presentes na matriz do biofilme, foi determinada através da metodologia de Lowry utilizando BSA (albumina de soro bovina) para a curva padrão. O método se baseia em uma mistura de molibdato, tungstato e ácido fosfórico (reagente Folin Ciocalteau) que sofre uma redução quando reage com proteínas, na presença do catalisador $\mathrm{Cu}^{+2}$ e produz um composto em absorção máxima de $750 \mathrm{~nm}$ (ZAIA et al, 1998). As amostras puras ou diluídas foram dispostas em placas de microtitulação e adicionadas o reagente Folin, homogeneizadas em temperatura ambiente ao abrigo da luz. Após 5 min foi 
feita a leitura da absorbância em comprimento de onda de $750 \mathrm{~nm}$. A quantidade de proteínas da matriz pode ser quantificada em $\mu \mathrm{g}_{\text {proteína }} / \mathrm{mg}_{\text {biofilme }}$.

\subsubsection{Quantificação de DNA extracelular}

A quantificação do DNA extracelular presente foi realizada através de medidas em espectrofotômetro NanoDrop 1000 (Thermo Scientific), em comprimento de onda de $260 \mathrm{~nm}$. Para fazer a leitura no espectrofotômetro, utilizou-se $10 \mathrm{mg}$ de massa do biofilme em $50 \mu \mathrm{L}$ de água ultrapura e a partir dessa amostra alíquotas de (1-3 $\mu \mathrm{L})$ foram utilizadas para realização das medidas. Para estimar a concentração de DNA utiliza-se a seguinte relação: 1 $\mathrm{OD}_{260 \mathrm{~nm}}=50$ ng DNA dupla-hélice (SAMBROOK; RUSSEL, 2001). Para avaliar a qualidade das amostras de ácidos nucléicos é necessário observar a relação $\mathrm{Abs}_{260} / \mathrm{Abs}_{280}$, pois a mesma fornece um parâmetro de avaliação quanto a presença de contaminantes como:proteínas e RNA. Quando esssa proporção apresenta valores inferiores a 1,5 resulta de contaminação com proteína, valores entre 1,5 e 2,0 resulta em amostras puras e valores acima de 2,0 indicam contaminação com RNA (SAMBROOK; RUSSEL, 2001).

\subsection{Análise qualitativa dos biofilmes}

\subsubsection{Microscopia Eletrônica de Varredura}

Para avaliar qualitativamente a arquitetura e a presença da matriz polimérica extracelular (MPE), antes e após o tratamento com o ramnolipídeo, os biofilmes foram observados em Microscópio Eletrônico de Varredura (MEV). Os biofilmes foram formados conforme descrito anteriormente, utilizando-se cupons de poliestireno de $1 \mathrm{~cm}^{2}$, previamente higienizados e esterilizados. Em seguida as amostras foram submetidas a desidratação através da imersão em soluções contendo concentrações crescentes de álcool etílico $(10 \%, 25 \%, 40$ $\%, 50 \%, 70 \%, 80 \%, 90 \%$ e $95 \%$ ) permanecendo por 15 min em cada solução e deixadas secar em dessecador por 24 h (ZERAIK; NITSCHKE, 2012; GOMES, 2011). Foram avaliadas amostras controle (com biofilme não tratado) comparando-se com amostras submetidas ao tratamento com o RL em diferentes concentrações. 
As fotomicrografias de MEV foram obtidas na Central de Análises Químicas Instrumentais do Instituto de Química de São Carlos (CAQI/IQSC/USP) em equipamento ZEISS LEO 440 (Cambridge, England) com detector OXFORD (Modelo 7060), operando com feixe de elétrons de $15 \mathrm{kV}$, corrente de 3,20 A e I probe de $500 \mathrm{pA}$. As amostras foram recobertas com $6 \mathrm{~nm}$ de ouro em um metalizador Coating System BAL-TEC MED 020 (BALEC, Liechtenstein) e mantidas em dessecador até o momento das análises. Condições de metalização: pressão na câmara $=2,00 \cdot 10^{-2}$ mbar; corrente $=60 \mathrm{~mA}$; taxa de deposição 0,60 $\mathrm{nm} / \mathrm{s})$.

\subsubsection{Microscopia de Fluorescência}

Para realização das análises de microscopia de fluorescência utilizou-se o kit de viabilidade bacteriana BacLight ${ }^{\mathrm{TM}}$ LIVE/DEAD L7012- lot 1562296, (Molecular Probes by Life Technologies, EUA). Esse kit utiliza uma mistura com dois marcadores: o marcador verde fluorescente SYTO 9 (480/500 nm excitação/emissão) e o marcador vermelho fluorescente iodeto de propídeo (490/638 nm excitação/emissão). O SYTO 9 marca todas as bactérias presentes na amostra, viáveis e não-viáveis. Por outro lado, o iodeto de propídeo penetra apenas em bactéria com a membrana celular danificada (não-viáveis), causando a redução do SYTO 9 quando ambos os corantes estão presentes. Desse modo, quando há uma mistura apropriada dos dois marcadores, as bactérias que apresentam membrana celular intacta (viáveis) são marcadas em verde fluorescente, enquanto as células que apresentam danos na membrana celular (não-viáveis) são marcadas em vermelho fluorescente (MOREIRA; LINS, 2010).

Após a formação dos biofilmes (ver item 4.6) em cupons de poliestireno de $2 \mathrm{~cm}^{2}$, previamente higienizados e esterilizados, as células foram coradas de acordo com o protocolo experimental do fornecedor. Nos experimentos realizados neste trabalho foi utilizado uma proporção de 1:1 dos dois principais componentes do kit, sendo $3 \mu \mathrm{L}$ do componente A (SYTO 9 - 3,34 mM) e $3 \mu \mathrm{L}$ do componente B (Iodeto de Propídio - $20 \mathrm{mM}$ ) misturados a 1 $\mathrm{mL}$ de água destilada esterilizada e mantidos ao abrigo da luz. Em seguida adicionou-se 200 $\mu \mathrm{L}$ desta mistura de corantes nas superfícies dos biofilmes, e após 1-2 h de secagem em temperatura ambiente ao abrigo da luz, as amostras foram levadas ao microscópio de fluorescência BX-60 (Olympus) equipado com sistema para fluorescência e câmera digital, 
para observação das células viáveis e não-viáveis presentes nos biofilmes das bactérias de estudo.

\section{12 Análise das propriedades físico-químicas do ramnolipídeo}

\subsubsection{Determinação da concentração micelar crítica}

As medidas de concentração micelar crítica (CMC) foram determinadas usando um tensiômetro Attension (Modelo Sigma 700/701) e o cálculo do valor da CMC foi realizado utilizando-se o software Attension Sigma. Preparou-se $1.000 \mathrm{~mL}$ de uma solução de ramnolipídeo (25\%) com $99 \%$ de pureza, em pH 7,0 \pm 0,2 (o mesmo $\mathrm{pH}$ utilizado em todos os ensaios realizados neste trabalho), na concentração final igual à $1 \%$ (v/v). Essa solução foi diluída sucessivamente através de um dosador automático em um vasilhame contendo o anel de platina Du Nouy.

\subsubsection{Espalhamento dinâmico de luz.}

A interação da radiação eletromagnética com a matéria pode produzir vários efeitos, como: absorção, emissão, transmissão ou espalhamento. Em relação ao espalhamento de luz, o mesmo pode ocorrer quando o campo elétrico da radiação incidente em um átomo induz oscilações periódicas na sua nuvem eletrônica, passando a funcionar como fonte secundária de radiação. Quando essa radiação interage e atravessa a amostra, o instrumento registra o espalhamento causado pelas moléculas. Dessa forma, à partir do raio de espalhamento e da intensidade da radiação espalhada pode-se obter os dados sobre as dimensões das partículas (SCHMITZ, 1990).

O espalhamento dinâmico de luz mede flutuações instantâneas de intensidade que estão relacionadas com as propriedades dinâmicas das partículas. Essa intensidade é observada em um intervalo de tempo curto, que pode variar de segundo ou micro-segundo. As flutuações da intensidade de espalhamento detectadas no DLS estão relacionadas com o movimento Browniano das partículas devido as flutuações de densidade. Estas são causadas por aglomeração acidental de partículas e avaliação do número de moléculas no volume disperso. Dessa forma, o espalhamento dinâmico de luz mede a dependência da luz espalhada em um ângulo fixo em função do tempo. Sendo portanto muito útil na determinação de 
características estruturais de partículas, envolvendo uma relação inversa entre o seu tamanho e o ângulo de espalhamento (SANTOS; CASTANHO, 1996).

A dependência da intensidade de flutuação em relação ao tempo é uma função do tamanho da partícula. E a difusão regida pelo movimento Browniano é inversamente proporcional ao tamanho da partícula. Assim, partículas pequenas movem-se rapidamente e a luz espalhada mostra flutuações rápidas. Ao contrário, partículas grandes difundem-se vagarosamente de modo que o feixe de luz espalhada apresenta flutuações lentas. Entretanto, para que informações úteis sobre o tamanho de partículas sejam obtidas, é necessário examinar as propriedades estatísticas das flutuações da luz, o que é feito através da função de autocorrelação. Esta função descreve o quão rápido o sinal varia e quanto tempo o mesmo leva para perder a memória do valor anterior, em decorrência do movimento Browniano das partículas. A função de correlação é em geral uma função exponencial e está diretamente relacionada com o tamanho de partícula da amostra. O coeficiente de difusão pode ser obtido por meio da função de autocorrelação. O tamanho da partícula pode ser especificado pelo raio ou diâmetro. A medida da quantidade total de partículas de tamanho equivalente é uma função aditiva tal como volume, massa ou área superficial (PECORA, 1985).

As análises de flutuações em DLS estão relacionadas com a intensidade de flutuações e a velocidade de flutuação é relatada pelo coeficiente de difusão das espécies espalhadoras. Sendo a partícula espalhadora uma esfera, o raio equivalente com o mesmo coeficiente de difusão é definido como o raio hidrodinâmico e o parâmetro Z-Average é o diâmetro médio das partículas espalhadoras. Em solução as moléculas sofrem difusão constante, resultante de flutuações térmicas na suspensão associado ao "movimento Browniano". O coeficiente de difusão é relacionado ao tamanho do objeto de difusão. Sendo assim, se o coeficiente de difusão é medido e a viscosidade do solvente é conhecida, o raio hidrodinâmico pode ser calculado através da equação de Stokes- Einstein (PECORA, 1985):

$$
\mathrm{D}=\frac{k \mathrm{~T}}{6 \pi \eta \mathrm{R}_{\mathrm{h}}} \quad \text { Equação } 2
$$

Onde $\mathrm{k}$ é a constante de Boltzman, $\mathrm{T}$ a temperatura absoluta, $\eta$ a viscosidade do meio e $R_{h} \mathrm{O}$ raio hidrodinâmico das partículas espalhadoras, supondo que estas estão são esféricas. 
A técnica de DLS foi portanto empregada para medir os tamanhos das micelas de ramnolipídeo em várias condições de temperatura e concentração. Acredita-se que esses estudos poderão fornecer informações importantes para uma melhor compreensão das diferentes possibilidades de estruturas (micelas/vesículas/lamelas) que o ramnolipídeo pode formar em meio aquoso e tentar associar com sua ação na remoção de biofilmes.

Os experimentos de DLS foram realizados usando um equipamento Nano Zetasizer (Malvern), que encontra-se disponível no laboratório de Biofísica Molecular do Instituto de Química de São Carlos - IQSC. Este equipamento apresenta ângulo de espalhamento fixo em $173^{\circ}$ e dispõe de um laser que fornece a radiação para análise no comprimento de onda de $633 \mathrm{~nm}$. Os parâmetros de diâmetro hidrodinâmico em relação ao número de partículas e intensidade foram calculados a partir dos coeficientes de difusão obtidos por análise do software fornecido pelo instrumento. As análises com o ramnolipídeo foram realizadas em solução aquosa nas concentrações de $0,05 \%, 0,1 \%, 0,25 \%, 0,5 \%, 1 \%$ e $2 \%$ e nas temperaturas de $10{ }^{\circ} \mathrm{C}, 25^{\circ} \mathrm{C}$ e $37^{\circ} \mathrm{C}$. Devido às limitações do aparelho a menor temperatura possível de realização das medidas foi de $10{ }^{\circ} \mathrm{C}$.

\subsubsection{Espalhamento de raios-X a baixo ângulo}

A técnica Espalhamento de raios-X a baixo ângulo (SAXS) tem sido largamente empregada na determinação de estrutura em micro ou nano escala de um sistema de partículas, em função dos seguintes parâmetros: tamanho das partículas, forma, distribuição, razão entre a área e o volume (BARBOSA et al, 2006). Porém os padrões obtidos não fornecem informações sobre a morfologia diretamente; o resultado de um experimento de SAXS é essencialmente a intensidade da Transformada de Fourier da densidade eletrônica e precisa ser interpretado para determinar a morfologia da amostra. As amostras podem ser sólidas ou líquidas e podem conter domínios sólidos, líquidos ou gasosos do mesmo material ou de outro, sem a necessidade de muito tempo de preparação. Conceitualmente, é uma técnica simples: a amostra é exposta a radiação (raios-X) e a radiação espalhada é medida por um detector (BARBOSA, 2008).

Nos experimentos de SAXS, uma solução de macromoléculas é exposta aos raios-X onde a intensidade de radiação espalhada I(q) é função da transferência de momento q. A 
intensidade de espalhamento (I) de uma partícula depende de alguns fatores como a concentração da amostra ou o número de partículas (n) que espalham o raio- X, resultando na forma da partícula $(\mathrm{P}(\mathrm{q})$ ) e nas posições relativas entre elas (S(q)) (SVERGUN; FEIGIN, 1987).

$$
\mathrm{I}(\mathrm{q})=\mathrm{kn}_{\mathrm{p}} \mathrm{P}(\mathrm{q}) \mathrm{S}(\mathrm{q}) \quad \text { Equação } 3
$$

Neste trabalho, os experimentos de SAXS foram realizados no Laboratório Nacional de Luz Síncroton (LNLS, Campinas, SP), nas linhas de luz SAXS 1 e SAXS 2. As linhas de SAXS são equipadas com um detector bidimensional (Mar CCD) com $\lambda$ de radiação $1.608 \AA$ e a distância amostra-detector utilizada foi de $740 \mathrm{~mm}$, possibilitando coletar as curvas de espalhamento no intervalo de q entre 0,01 a $0,25 \AA^{-1}$, nas temperaturas de 15 e $37{ }^{\circ} \mathrm{C}$. As amostras contendo as soluções aquosas de ramnolipídeo nas concentrações de 0,25 \%, 0,5 \%, $1 \%$ e $2 \%$ foram acondicionadas em porta-amostra de $300 \mu \mathrm{L}$, com janelas de mica, com feixe de raio-x incidente perpendicular.

Após a aquisição dos dados de SAXS (tempo de aquisição de $15 \mathrm{~min}$ ), várias correções foram necessárias antes que as curvas de espalhamento pudessem ser utilizadas para o estudo estrutural do sistema em questão. Mesmo que a medida tenha sido realizada sob vácuo existe sempre um espalhamento adicional causado pelos elementos ópticos inseridos no caminho do feixe após a amostra (fendas, janelas, soluções tampões, etc). Os dados corrigidos das curvas de SAXS são então obtidos em valores de intensidade de espalhamento I (q) a. u. em função do vetor de espalhamento (q $\left.\AA^{-1}\right)$.

\section{13 Descarte do material}

Todos os materiais descartáveis utilizados no desenvolvimento deste trabalho contendo bactérias patogênicas foi submetido ao aquecimento em autoclave a $121{ }^{\circ} \mathrm{C}$ por 30 min, antes de ser descartado em lixo comum. Quanto ao material não descartável, o mesmo foi deixado em solução de hipoclorito de sódio por 24 h antes de ser devidamente higienizado e reutilizado. 


\subsection{Análise estatística}

Os ensaios microbiológicos foram expressos como a média de no mínimo três repetições independentes. Os dados obtidos foram comparados através de análise de variância (ANOVA) ao nível de $95 \%$ de probabilidade e o teste de Tukey foi usado para avaliar as diferenças entre as médias. As análises foram feitas utilizando o software Origin v. 9 (OriginLab Corporation). 


\section{RESULTADOS E DISCUSSÃO}

\subsection{Padronização do inóculo}

A padronização do inóculo no meio de cultura específico para o crescimento de cada bactéria foi realizado através do procedimento de contagem pelo método de gota, relacionacionando o número de células viáveis com as medidas de densidade óptica. Este ensaio possibilitou a padronização do inóculo a ser usado em experimentos posteriores nas mesmas condições, o que aumenta a reprodutibilidade. Na Figura 10 é possível observar a técnica de gotas para cada bactéria de estudo, onde foi possível a realização da contagem apenas na diluição $10^{-6}$.

Figura 10- Procedimento de contagem pelo método de gota. (A) Escherichia coli ATCC 43895, (B) Staphylococcus aureus ATCC 8095 ambas em ágar nutriente e (C) Listeria monocytogenes ATCC 19112 em TSYEA.
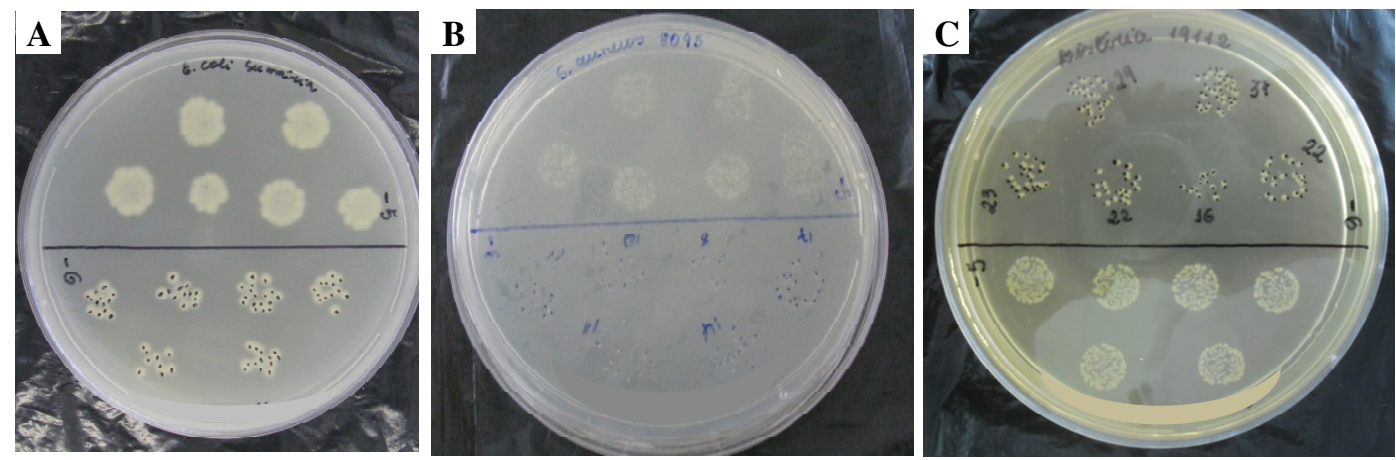

Assim, de acordo com a Tabela 3 foi possível observar os diferentes valores de unidades formadoras de colônia para cada bactéria de estudo. Esses valores foram usados de forma a padronizar todos os inóculos utilizados durante os experimentos com as bactérias de estudo para formação de biofilmes.

Tabela 3- Contagem do número de células viáveis (UFC mL ${ }^{-1}$ ) obtidas para os microrganismos de estudo.

\begin{tabular}{ccc}
\hline Microrganismos & Meios de cultura & D.O./ $\mathbf{~} \mathbf{C C ~ \mathbf { ~ m } ^ { - \mathbf { 1 } }}$ \\
\hline Escherichia coli 43895 & $\mathrm{CN}$ & $0,83 / 0,86 \times 10^{9}$ \\
Staphylococcus aureus 8095 & $\mathrm{CN}$ & $0,82 / 0,80 \times 10^{9}$ \\
Listeria monocytogenes 19112 & TSYEA & $0,86 / 1,5 \times 10^{9}$ \\
\hline
\end{tabular}


Este parâmetro é considerado extremamente importante pois o número inicial de microrganismos presente influencia a formação de biofilme. Segundo Andrade e colaboradores, (2008) para ser considerado um biofilme, é necessário apresentar um número mínimo de $10^{7} \mathrm{UFC} / \mathrm{cm}^{2}$, enquanto que Ronner e Wong, (1993) consideram como biofilme um número de células aderidas de $10^{5} \mathrm{UFC} / \mathrm{cm}^{2} \mathrm{e}$ Wirtanen e colaboradores, (1996) um valor

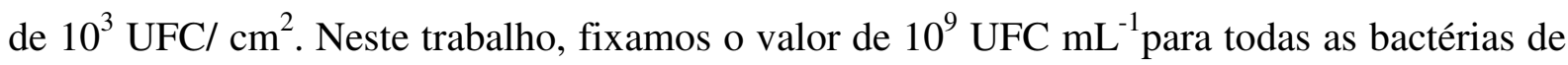
estudo para garantir o maior número de células na etapa inicial de formação dos biofilmes. Porém, é válido ressaltar que, mesmo que o número de células microbianas aderidas à superfície esteja abaixo do necessário para se considerar a formação de um biofilme maduro, o risco de contaminação microbiológica do alimento já existe, a partir de microrganismos sésseis presentes na superfície (OLIVEIRA; BRUGNERA; PICCOLI, 2010).

\subsection{Formação e caracterização dos biofilmes formados pelos diferentes microrganismos}

Para verificar a capacidade de formação de biofilme em superfície abiótica foi necessário realizar previamente ensaios cinéticos com os microrganismos de estudo, em microplacas de poliestireno com 96 cavidades. Esta técnica possibilitou visualizar a formação de biofilmes em diferentes tempos $(0-72 \mathrm{~h})$, à $37^{\circ} \mathrm{C}$. Os resultados dos testes de formação de biofilmes são apresentados na Figura 11. O gráfico abaixo mostra que houve uma maior formação de biofilme em poliestireno para $S$. aureus e L. monocytogenes, em relação à $E$. coli. Apesar dessa diferença as bactérias em geral têm uma tendência natural para aderir a superfícies como um mecanismo de sobrevivência. E além disso, propriedades da superfície da célula, como apresença de flagelo, fimbrias, pili, proteínas adesinas, lipopolissacarídeos, ácido lipoteicoico e cápsula, influenciam na adesão à superficie (OLIVEIRA; BRUGNERA; PICCOLI, 2010).

Estudos indicam que de modo geral, toda superfície é vulnerável ao desenvolvimento de biofilme incluindo plástico, vidro, metal, madeira, e produtos alimentares (ABDALLAH et al., 2014). Sinde e Carballo (2000) relataram que Salmonella e Listeria apresentam maior capacidade de adesão em superfícies hidrofóbicas do que em superfícies hidrofílicas. Além disso, as superfícies cobertas por macromoléculas, tais como substâncias orgânicas, favorecem ainda mais adesão de algumas células bacterianas (SREY et al., 2014). Dessa maneira, a adesão bacteriana é um processo bastante complexo que envolve a interação 
multifacetada de três componentes: bactéria, superfície (hidrofobicidade, rugosidade, carga superficial, etc) e microambiente ( $\mathrm{pH}$, disponibilidade nutricional, inóculo bacteriano, etc) em que eles se encontram (TRENTIN; GIORDANI; MACEDO, 2013).

Figura 11- Estudo preliminar de formação de biofilme de E. coli ATCC 43895, S. aureus ATCC 8095 e $L$. monocytogenes ATCC 19112, à $37^{\circ} \mathrm{C}$ em microplaca de poliestireno.

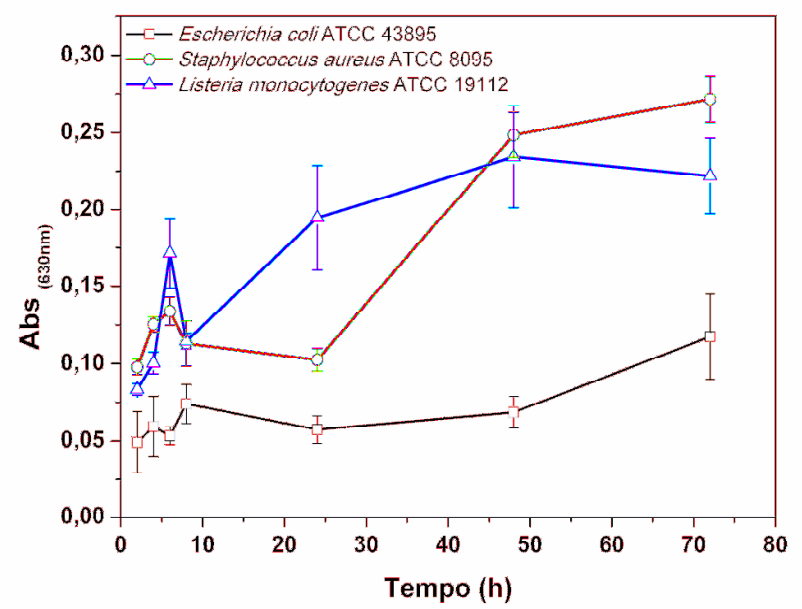

O poliestireno, um material usado na indústria de alimentos possui características hidrofóbicas. Sabe-se que os materiais hidrofóbicos são mais resistentes a adesão bacteriana do que superfícies hidrofílicas (MYSZKA; CZACZYK, 2011). Os fatores ambientais como pH, temperatura, composição do meio de cultivo, e características bacterianas também desempenham papéis importantes na alteração do fenótipo de células planctônicas (livres) para a forma séssil (MYSZKA; CZACZYK, 2011; SREY et al., 2014).

Como podemos observar na Figura 12 há mudanças significativas em relação à formação de biofilmes dos diferentes microrganismos estudados. Em meio comercial (Figura 12A) há uma maior adesão das bactérias Gram-positivas, no caso $S$. aureus e $L$. monocytogenes, e em leite (Figura 12B), houve uma significativa adesão de E.coli e $S$. aureusem comparação à L. monocytogenes. De acordo com Bremer et al., (2009) componentes do leite como a caseína e $\beta$-lactoglobulina podem interferir na adesão de $L$. monocytogenes e Salmonella typhimurium em aço inoxidável. Observa-se o mesmo comportamento para superfície de poliestireno, onde houve uma redução da formação de biofilme de L. monocytogenes. A razão dessa redução pode ser explicada devido ao fato de que as proteínas do leite competem com a superfície de poliestireno, reduzindo assim o número de sítios para a bactéria. Entretanto, para $S$. aureus e E. coli observou-se um aumento 
na adesão bacteriana no decorrer do tempo, constatando-se que o leite é um ótimo substrato para o crescimento/adesão de algumas bactérias.

Figura 12- Cinéticas de formação de biofilmes de E. coli ATCC 43895, S. aureus ATCC 8095 e $L$. monocytogenes ATCC 19112 em microplaca de poliestireno à $37^{\circ} \mathrm{C}$ usando (A) meio de cultura comercial e (B) leite.
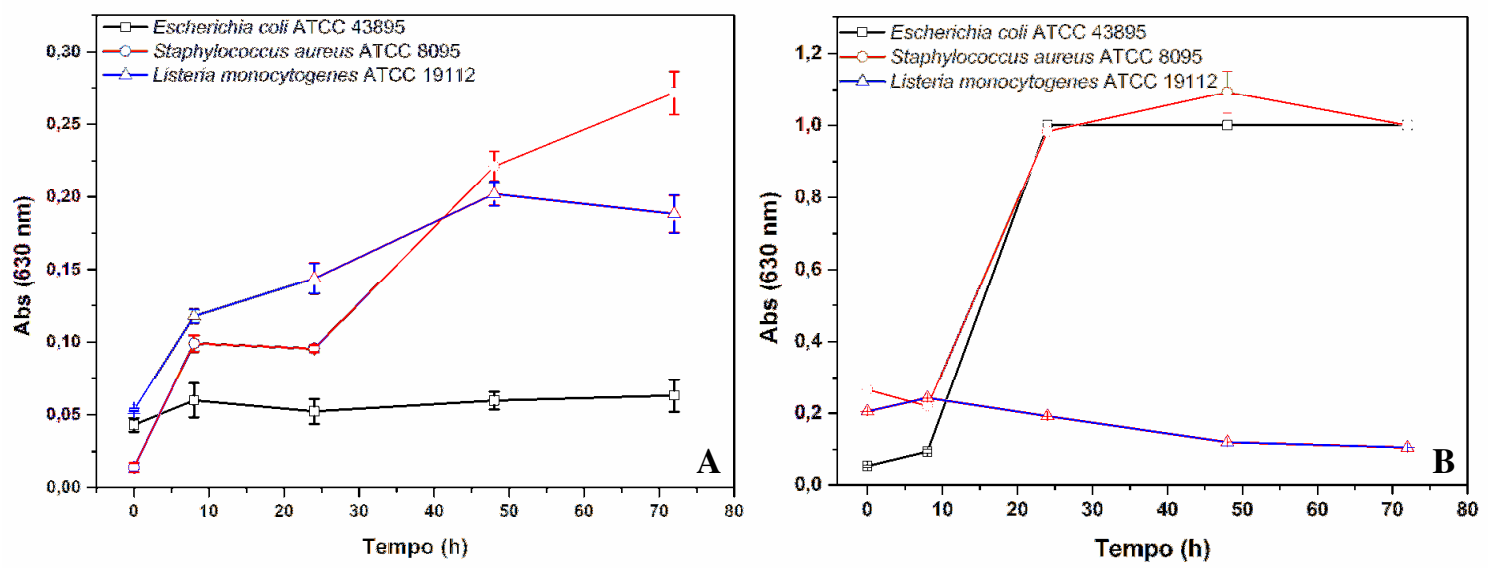

A partir dos resultados mostrados na Figura 12 foi possível observar as diferenças nas capacidades de formação de biofilmes dos microrganismos de estudo em superfície de poliestireno usando diferentes meios de cultivo em função do tempo. Também foi possível determinar o período de formação dos biofilmes a serem tratados com o ramnolipídeo em experimentos posteriores. Sendo que foi escolhido o tempo de $48 \mathrm{~h}$ para formação de biofilmes de S. aureus ATCC 8095 (caldo nutriente e leite) e L. monocytogenes ATCC 19112 (extrato de levedura com triptona de soja e leite) e para o biofilme de E. coli ATCC 43895 (caldo nutriente e leite) o tempo de $24 \mathrm{~h}$.

\subsection{Análise do tratamento dos biofilmes com ramnolipídeo}

5.4.1 Quantificação da biomassa celular: influência da temperatura, meio de cultivo e concentração

Nesta seção são mostrados os resultados dos tratamentos dos biofilmes com ramnolipídeo, nas concentrações de $0,05 \%, 0,1 \%, 0,25 \%, 0,5 \%, 1 \%$ e $2 \%$, por $2 \mathrm{~h}$, para as bactérias E. coli, S. aureus e L. monocytogenes, na presença dos meios nutritivos: caldo nutriente, TSYE e leite. 
De acordo com a Figura 13A podemos observar que o tratamento do biofilme de $E$. coli em caldo nutriente indicou diferença significativa para a maioria das concentrações analisadas, em relação ao controle, além de notável influência da temperatura. O resultado de remoção mais expressivo foi à $25^{\circ} \mathrm{C}$, na concentração $2 \%$ de RL, com remoção de $33 \%$ da biomassa celular (Tabela 4). Já o tratamento do biofilme formado em leite (Figura 13B) apresentou-se menos suscetível à ação do ramnolipídeo na maioria das condições analisadas. Porém houve uma remoção expressiva de $80 \%$ do biofilme usando $2 \%$ de RL na temperatura de $37^{\circ} \mathrm{C}$ (Tabela 5).

No geral observa-se que os biofilmes de E. coli formados tanto em caldo nutriente, quanto em leite apresentam uma tendência de maior remoção, em maiores concentrações de ramnolipídeo independente do meio nutricional e da temperatura analisados. Porém a temperatura foi mais influente em caldo nutriente quando comparado com o leite.

Para os biofilmes formados por S. aureus em caldo nutriente (Figura 14A) houve uma maior remoção à $25^{\circ} \mathrm{C}$, porém em concentração de RL mais baixa, $0,1 \%$, chegando aproximadamente à $35 \%$, como mostrado na Tabela 6. Observa-se que quando em altas concentrações nas temperaturas estudadas o efeito da remoção é desfavorecido promovendo até mesmo um aumento do biofilme. Já para biofilmes de $S$. aureus formados na presença do leite (Figura 14B), o efeito de remoção promovido pelo RL foi mais efetivo, independente da temperatura, com uma pequena vantagem à $25^{\circ} \mathrm{C}$, onde chegou-se à valores em torno de 87 \% de remoção (Tabela 7). Na mesma tabela notamos que não houve diferença significativa entre as diversas concentrações de RL utilizadas.

Para biofilme de L. monocytogenes em meio TSYE (Figura 15A), o tratamento mais sensível à ação do RL foi à $37{ }^{\circ} \mathrm{C}$ na concentração de $0,5 \%$. Não havendo diferença significativa entre as concentrações intermediárias $(0,1 ; 0,25$ e $1 \%)$, como observado na Tabela 8. Enquanto que para os biofilmes formados na presença do leite (Figura 15B) a ação do RL foi mais pronunciada em temperaturas mais baixas, no caso $4{ }^{\circ} \mathrm{C}$, chegando a $63,6 \%$, na concentração 0,5\% de RL (Tabela 9). A análise estatística indicou que não houve diferença significativa entre as concentrações intermediárias $(0,25$ e $1 \%)$ à $4{ }^{\circ} \mathrm{C}$. Os resultados também evidenciaram que em geral quanto maior a concentração de ramnolipídeo maior a remoção dos biofilmes, sendo que para concentrações acima de 0,5\%, em ambos os meios de cultivos, o porcentual de remoção diminuiu. Portanto as concentrações 
intermediárias de ramnolipídeo como 0,25 e $0,5 \%$ indicaram melhor ação para esse tipo de biofilme independente do meio de cultivo e da temperatura de tratamento.

Figura 13- Quantificação da biomassa celular do biofilme de E.coli ATCC 43895 em caldo nutriente (A) e leite (B), após o tratamento de $2 \mathrm{~h}$ com RL. Os dados representam a média de no mínimo três repetições independentes.

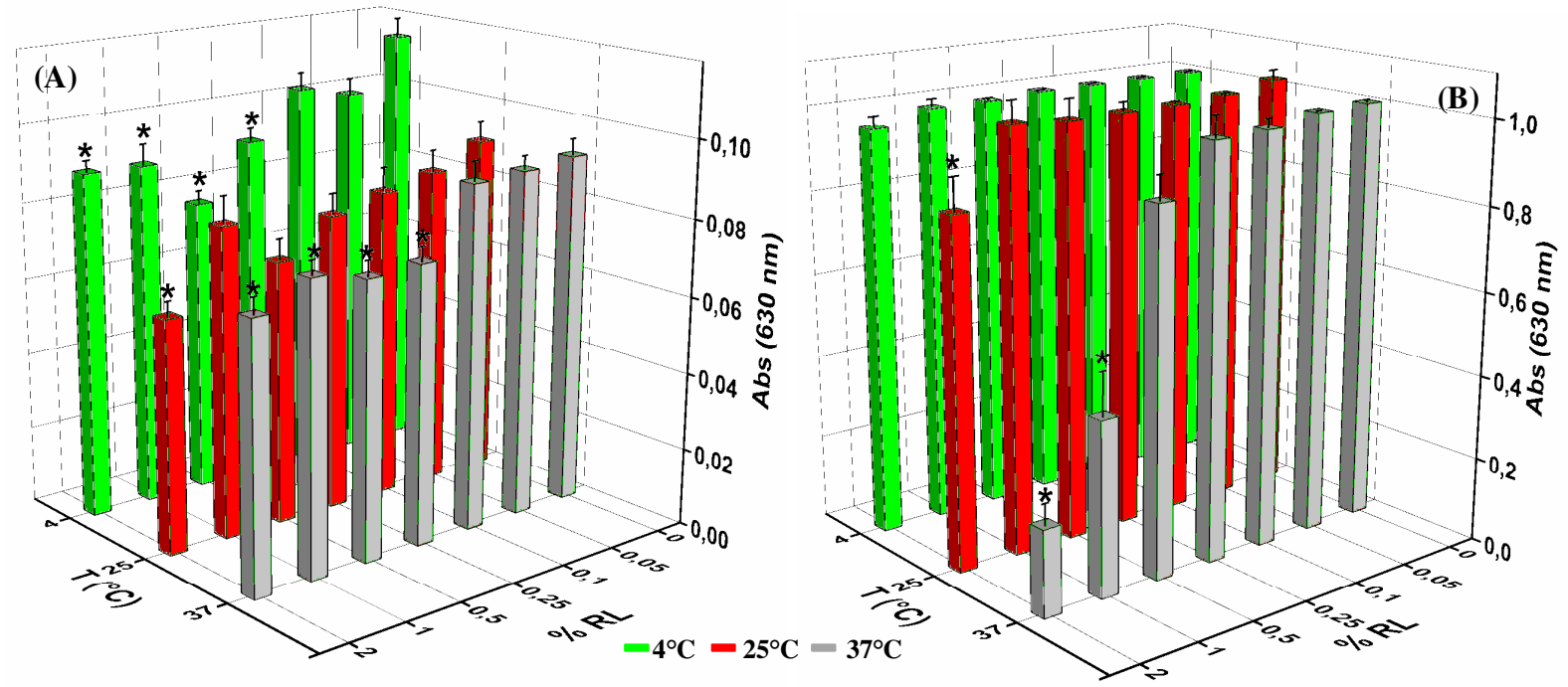

Para cada temperatura o símbolo (*) significa que diferem significativamente $p<0,05$ em relação ao controle.

Tabela 4- Porcentagem de remoção dos biofilmes E. coli ATCC 43895 formados em caldo nutriente- CN, após 2 $\mathrm{h}$ de tratamento com RL em diferentes condições de concentraçãoe temperatura.

\begin{tabular}{ccccc}
\hline Meio & \% RL & \multicolumn{3}{c}{ \% Remoção* } \\
\hline & 0,05 & $4^{\circ} \mathrm{C}$ & $25^{\circ} \mathrm{C}$ & $37^{\circ} \mathrm{C}$ \\
\cline { 2 - 5 } & 0,1 & $13,2^{\mathrm{A}, \mathrm{a}}$ & $6,6^{\mathrm{B}, \mathrm{a}}$ & $1,2^{\mathrm{B}, \mathrm{a}}$ \\
$\mathrm{CN}$ & 0,25 & $9,6^{\mathrm{A}, \mathrm{a}}$ & $10,0^{\mathrm{A}, \mathrm{a}}$ & $2,2^{\mathrm{B}, \mathrm{a}}$ \\
& 0,5 & $20,2^{\mathrm{A}, \mathrm{b}}$ & $14,4^{\mathrm{A}, \mathrm{a}}$ & $20,8^{\mathrm{A}, \mathrm{b}}$ \\
& 1 & $32,4^{\mathrm{A}, \mathrm{b}}$ & $24,4^{\mathrm{A}, \mathrm{b}}$ & $20,8^{\mathrm{A}, \mathrm{b}}$ \\
& 2 & $21,9^{\mathrm{A}, \mathrm{b}}$ & $11,1^{\mathrm{A}, \mathrm{a}}$ & $17,6^{\mathrm{A}, \mathrm{b}}$ \\
& $21,9^{\mathrm{A}, \mathrm{b}}$ & $33,3^{\mathrm{B}, \mathrm{b}}$ & $25,3^{\mathrm{B}, \mathrm{b}}$ \\
\hline
\end{tabular}

*Em cada linha os valores seguidos da mesma letra maiúscula não diferem significativamente $p<0,05$.

*Em cada coluna os valores seguidos da mesma letra minúscula não diferem significativamente $p<0,05$.

Tabela 5- Porcentagem de remoção dos biofilmes E.coli ATCC 43895 formados em leite, após 2 h de tratamento com RL em diferentes condições de concentraçãoe temperatura.

\begin{tabular}{lcccc}
\hline Meio & \% RL & \multicolumn{3}{c}{ \% Remoção* } \\
\hline & & $4^{\circ} \mathrm{C}$ & $25^{\circ} \mathrm{C}$ & $37^{\circ} \mathrm{C}$ \\
\cline { 2 - 5 } Leite & 0,05 & $0^{\mathrm{A}, \mathrm{a}}$ & $0^{\mathrm{A}, \mathrm{a}}$ & $0^{\mathrm{A}, \mathrm{a}}$ \\
& 0,1 & $0^{\mathrm{A}, \mathrm{a}}$ & $1^{\mathrm{A}, \mathrm{a}}$ & $2^{\mathrm{A}, \mathrm{a}}$ \\
& 0,25 & $0^{\mathrm{A}, \mathrm{a}}$ & $1^{\mathrm{A}, \mathrm{a}}$ & $3^{\mathrm{A}, \mathrm{a}}$ \\
& 0,5 & $1^{\mathrm{A}, \mathrm{a}}$ & $1^{\mathrm{A}, \mathrm{a}}$ & $14^{\mathrm{B}, \mathrm{b}}$ \\
& 1 & $1^{\mathrm{A}, \mathrm{a}}$ & $0^{\mathrm{A}, \mathrm{a}}$ & $59^{\mathrm{B}, \mathrm{c}}$ \\
& 2 & $4^{\mathrm{A}, \mathrm{a}}$ & $18^{\mathrm{B}, \mathrm{b}}$ & $80^{\mathrm{C}, \mathrm{d}}$ \\
\hline
\end{tabular}

*Em cada linha os valores seguidos da mesma letra maiúscula não diferem significativamente $p<0,05$.

*Em cada coluna os valores seguidos da mesma letra minúscula não diferem significativamente $p<0,05$. 
Figura 14- Quantificação da biomassa celular do biofilme formado por S. aureus ATCC 8095, em caldo nutriente (A) e leite (B), após o tratamento de $2 \mathrm{~h}$ com RL. Os dados representam a média de no mínimo três repetições independentes.

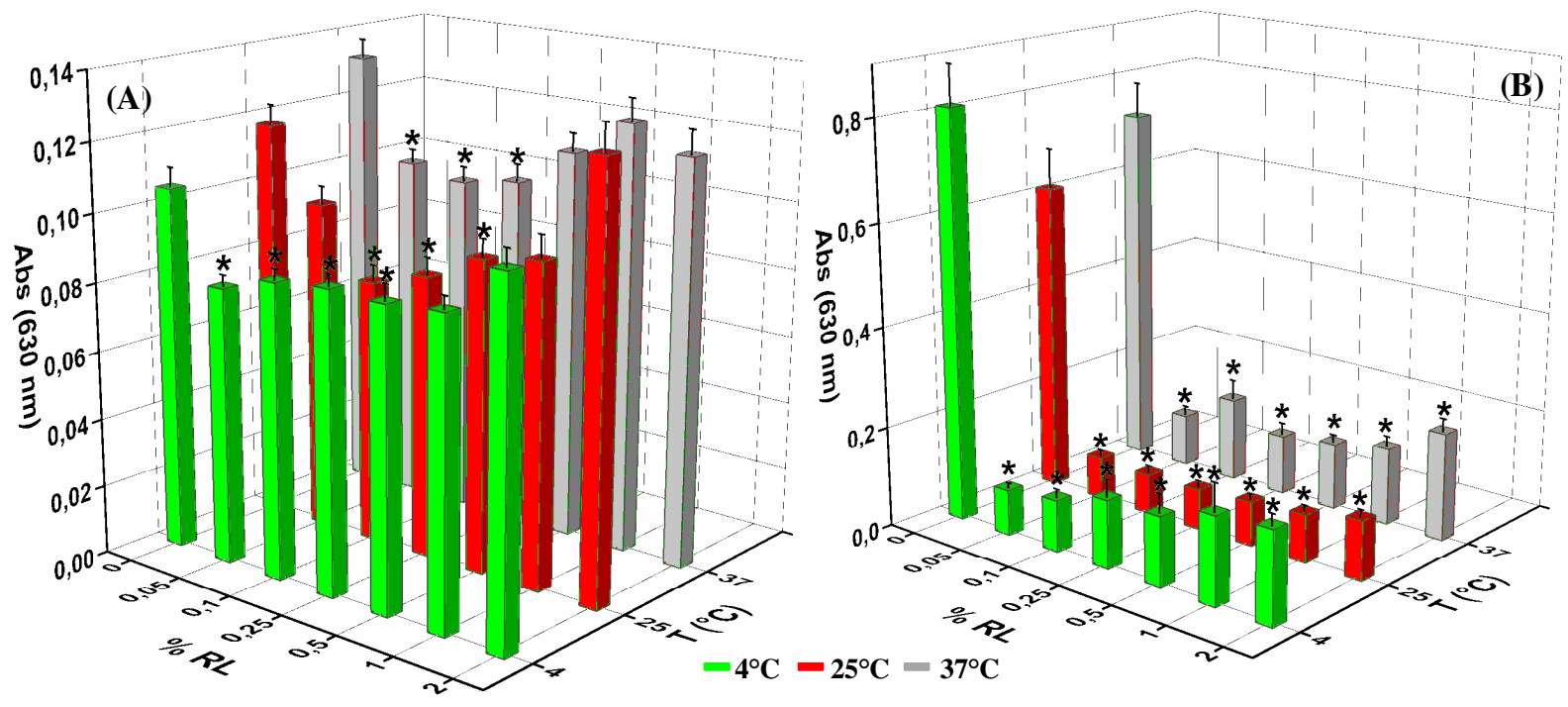

Para cada temperatura o símbolo (*) significa que diferem significativamente $p<0,05$ em relação ao controle.

Tabela 6- Porcentagem de remoção dos biofilmes S. aureus ATCC 8095 formados em caldo nutriente- CN, após $2 \mathrm{~h}$ de tratamento com RL em diferentes condições de concentraçãoe temperatura.

\begin{tabular}{ccccc}
\hline Meio & \% RL & \multicolumn{3}{c}{ \% Remoção* } \\
\hline & & $4^{\circ} \mathrm{C}$ & $25^{\circ} \mathrm{C}$ & $37^{\circ} \mathrm{C}$ \\
\cline { 2 - 4 } & 0,05 & $24,5^{\mathrm{A}, \mathrm{a}}$ & $17,8^{\mathrm{B}, \mathrm{a}}$ & $21,9^{\mathrm{A}, \mathrm{a}}$ \\
$\mathrm{CN}$ & 0,1 & $18,8^{\mathrm{A}, \mathrm{a}}$ & $34,7^{\mathrm{B}, \mathrm{b}}$ & $24,2^{\mathrm{A}, \mathrm{a}}$ \\
& 0,25 & $16,9^{\mathrm{A}, \mathrm{a}}$ & $29,6^{\mathrm{B}, \mathrm{b}}$ & $22,7^{\mathrm{A}, \mathrm{a}}$ \\
& 0,5 & $17,9^{\mathrm{A}, \mathrm{a}}$ & $22,8^{\mathrm{A}, \mathrm{a}}$ & $13,6^{\mathrm{B}, \mathrm{b}}$ \\
& 1 & $16,9^{\mathrm{A}, \mathrm{a}}$ & $20,3^{\mathrm{A}, \mathrm{a}}$ & $5,3^{\mathrm{B}, \mathrm{b}}$ \\
& 2 & $2,8^{\mathrm{A}, \mathrm{b}}$ & $-5,9^{\mathrm{B}, \mathrm{c}}$ & $10,6^{\mathrm{C}, \mathrm{b}}$ \\
\hline
\end{tabular}

*Em cada linha os valores seguidos da mesma letra maiúscula não diferem significativamente $p<0,05$.

*Em cada coluna os valores seguidos da mesma letra minúscula não diferem significativamente $p<0,05$.

Tabela 7- Porcentagem de remoção dos biofilmes S. aureus ATCC 8095 formados em leite, após 2h de tratamento com RL em diferentes condições de concentraçãoe temperatura.

\begin{tabular}{lcccc}
\hline Meio & \% RL & \multicolumn{3}{c}{ \% Remoção* } \\
\hline & & $4^{\circ} \mathrm{C}$ & $25^{\circ} \mathrm{C}$ & $37^{\circ} \mathrm{C}$ \\
\cline { 2 - 4 } Leite & 0,05 & $88,9^{\mathrm{A}, \mathrm{a}}$ & $86,2^{\mathrm{A}, \mathrm{a}}$ & $85,2^{\mathrm{A}, \mathrm{a}}$ \\
& 0,1 & $87,3^{\mathrm{A}, \mathrm{a}}$ & $86,9^{\mathrm{A}, \mathrm{a}}$ & $76,6^{\mathrm{A}, \mathrm{a}}$ \\
& 0,25 & $83,3^{\mathrm{A}, \mathrm{a}}$ & $86,6^{\mathrm{A}, \mathrm{a}}$ & $83,2^{\mathrm{A}, \mathrm{a}}$ \\
& 0,5 & $82,9^{\mathrm{A}, \mathrm{a}}$ & $85,5^{\mathrm{A}, \mathrm{a}}$ & $81,4^{\mathrm{A}, \mathrm{a}}$ \\
& 1 & $78,6^{\mathrm{A}, \mathrm{a}}$ & $84,2^{\mathrm{A}, \mathrm{a}}$ & $78,6^{\mathrm{A}, \mathrm{a}}$ \\
& 2 & $77,6^{\mathrm{A}, \mathrm{a}}$ & $80,6^{\mathrm{A}, \mathrm{a}}$ & $70,0^{\mathrm{A}, \mathrm{a}}$ \\
\hline
\end{tabular}

*Em cada linha os valores seguidos da mesma letra maiúscula não diferem significativamente $p<0,05$.

*Em cada coluna os valores seguidos da mesma letra minúscula não diferem significativamente $p<0,05$. 
Figura 15- Quantificação da biomassa celular do biofilme formado por L. monocytogenes ATCC 19112, em TSYE (A) e leite (B), após o tratamento de $2 \mathrm{~h}$ com RL. Os dados representam a média de no mínimo três repetições independentes.

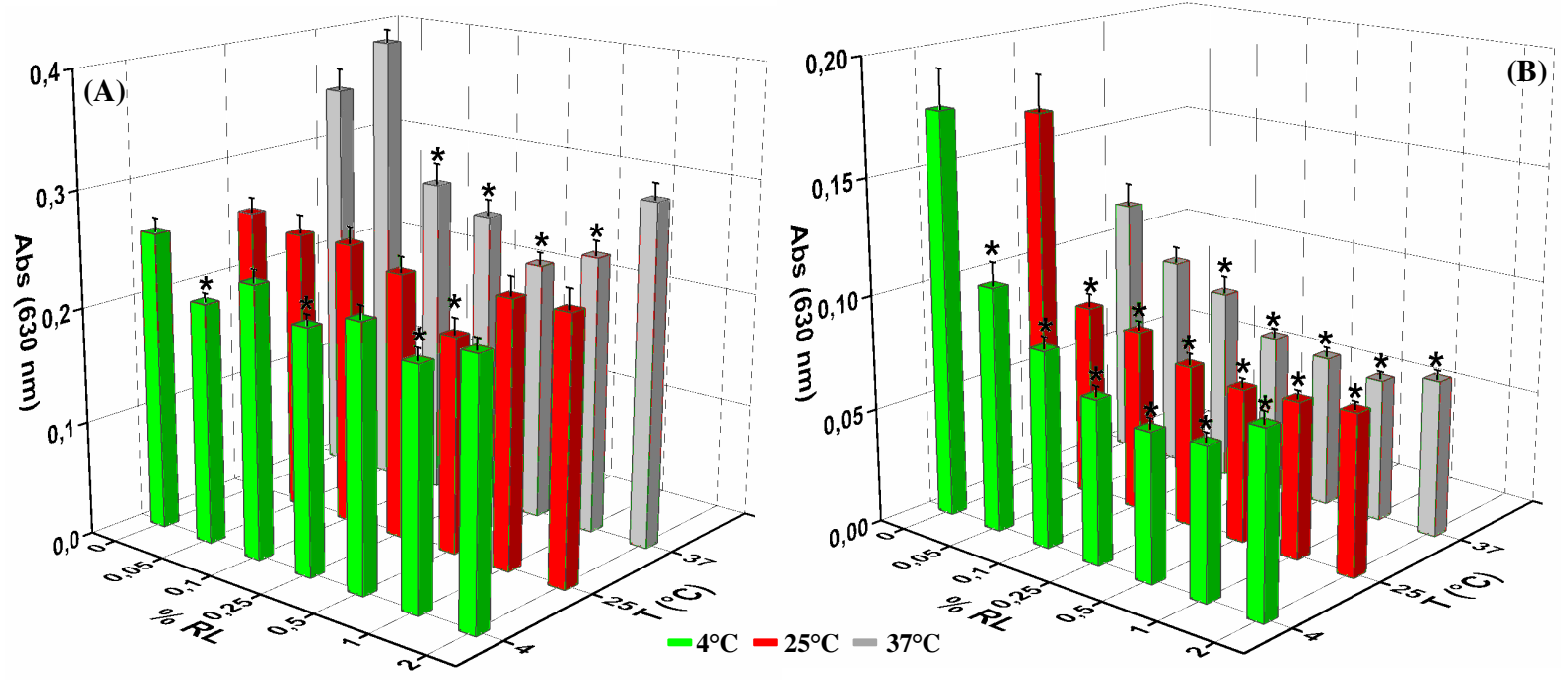

Para cada temperatura o símbolo (*) significa que diferem significativamente $p<0,05$ em relação ao controle.

Tabela 8- Porcentagem de remoção dos biofilmes L. monocytogenes ATCC 19112 formados em TSYE, após 2 h de tratamento com RL em diferentes condições de concentraçãoe temperatura.

\begin{tabular}{ccccc}
\hline Meio & \% RL & \multicolumn{3}{c}{ \% Remoçã Re $^{*}$} \\
\hline & & $4^{\circ} \mathrm{C}$ & $25^{\circ} \mathrm{C}$ & $37^{\circ} \mathrm{C}$ \\
\cline { 2 - 4 } TSYE & 0,05 & $19,3^{\mathrm{A}, \mathrm{a}}$ & $3,50^{\mathrm{B}, \mathrm{a}}$ & $-14,1^{\mathrm{C}, \mathrm{a}}$ \\
& 0,1 & $8,8^{\mathrm{A}, \mathrm{b}}$ & $3,1^{\mathrm{B}, \mathrm{a}}$ & $19,8^{\mathrm{C}, \mathrm{b}, \mathrm{d}}$ \\
& 0,25 & $18,1^{\mathrm{A}, \mathrm{a}}$ & $9,0^{\mathrm{B}, \mathrm{a}}$ & $25,8^{\mathrm{C}, \mathrm{b}, \mathrm{c}}$ \\
& 0,5 & $11,9^{\mathrm{A}, \mathrm{b}}$ & $25,8^{\mathrm{B}, \mathrm{b}}$ & $35,3^{\mathrm{C}, \mathrm{c}}$ \\
& 1 & $20,8^{\mathrm{A}, \mathrm{a}}$ & $9,0^{\mathrm{B}, \mathrm{a}}$ & $30,5^{\mathrm{C}, \mathrm{c}}$ \\
& 2 & $13,1^{\mathrm{A}, \mathrm{b}}$ & $9,0^{\mathrm{B}, \mathrm{a}}$ & $14,4^{\mathrm{A}, \mathrm{d}}$ \\
\hline
\end{tabular}

*Em cada linha os valores seguidos da mesma letra maiúscula não diferem significativamente $p<0,05$.

*Em cada coluna os valores seguidos da mesma letra minúscula não diferem significativamente $p<0,05$.

Tabela 9- Porcentagem de remoção dos biofilmes L. monocytogenes ATCC 19112 formados em leite, após 2h de tratamento com RL em diferentes condições de concentraçãoe temperatura.

\begin{tabular}{ccccc}
\hline Meio & \% RL & \multicolumn{3}{c}{ \% Remoção* } \\
\hline & & $4^{\circ} \mathrm{C}$ & $25^{\circ} \mathrm{C}$ & $37^{\circ} \mathrm{C}$ \\
\cline { 2 - 4 } Leite & 0,05 & $39,7^{\mathrm{A}, \mathrm{a}}$ & $48,8^{\mathrm{A}, \mathrm{a}}$ & $19,1^{\mathrm{B}, \mathrm{a}}$ \\
& 0,1 & $51,7^{\mathrm{A}, \mathrm{b}}$ & $52,4^{\mathrm{A}, \mathrm{a}}$ & $26,9^{\mathrm{B}, \mathrm{a}}$ \\
& 0,25 & $59,6^{\mathrm{A}, \mathrm{c}}$ & $57,8^{\mathrm{A}, \mathrm{a}}$ & $40,0^{\mathrm{B}, \mathrm{b}}$ \\
& 0,5 & $63,6^{\mathrm{A}, \mathrm{c}}$ & $60,2^{\mathrm{A}, \mathrm{a}}$ & $42,6^{\mathrm{B}, \mathrm{b}}$ \\
& 1 & $63,1^{\mathrm{A}, \mathrm{c}}$ & $59,0^{\mathrm{A}, \mathrm{a}}$ & $46,1^{\mathrm{B}, \mathrm{b}}$ \\
& 2 & $55,1^{\mathrm{A}, \mathrm{b}}$ & $58,4^{\mathrm{A}, \mathrm{a}}$ & $40,8^{\mathrm{B}, \mathrm{b}}$ \\
\hline
\end{tabular}

*Em cada linha os valores seguidos da mesma letra maiúscula não diferem significativamente $p<0,05$.

*Em cada coluna os valores seguidos da mesma letra minúscula não diferem significativamente $p<0,05$. 
Os resultados sugerem que a ação do ramnolipídeo quanto atemperatura e concentração é bem variável entre as bactérias de estudo. No entanto, percebe-se que os biofilmes formados pelas bactérias Gram-positivas (L. monocytogenes e S. aureus) foram mais susceptíveis à ação do ramnolipídeo em concentrações e temperaturas mais baixas. Em contraste o biofilme de $E$. coli que apresentou-se mais susceptível em maiores temperaturas e concentrações de ramnolipídeo, como podemos observar no resumo dos principais resultados apresentados na Tabela 10.

Tabela 10- Principais resultados de remoção dos biofilmes frente à ação de RL.

\begin{tabular}{lcccc}
\hline \multirow{2}{*}{ Microrganismos } & \multicolumn{3}{c}{ Condições de tratamento } & \\
\cline { 2 - 4 } E. coli & Meios & T $\left({ }^{\circ} \mathbf{C}\right)$ & RL(\%) & Remoção (\%) \\
\cline { 2 - 4 } & CN & 25 & 2 & 33,3 \\
Leite & 37 & 2 & 80 \\
& & & & \\
& CN aureus & 25 & 0,1 & 34,7 \\
& Leite & 4 & 0,05 & 88,9 \\
L. monocytogenes & TSYE & 37 & 0,5 & 35,3 \\
& Leite & 4 & 0,5 & 63,6 \\
\hline
\end{tabular}

A remoção de biofilmes com ramnolipídeo pode ser influenciada por inúmeros fatores, como: a concentração, tempo de contato e temperatura. Em estudos realizados com o ramnolipídeo mediando a remoção de biofilme da bactéria marinha Bacillus pumilus em $1 \mathrm{~h}$ de tratamento, na concentração 1,6 mM não houve remoção da matriz polimérica extracelular (MPE), porém após $24 \mathrm{~h}$ houve remoção significativa das células associadas no biofilme (DUSANE, et al., 2010). No entanto, Gomes e Nitschke, (2012) relataram que o fator tempo de contato não apresentou diferença significativa para os biofilmes de $S$. aureus e $L$. monocytogenes durante 2, 6 e $12 \mathrm{~h}$ de incubação com o RL e baseado nisso, todos os tratamentos realizados neste trabalho foram fixados em $2 \mathrm{~h}$.

A influência do aumento da concentração foi mais efetivo para promover a remoção dos biofilmes de E. coli, a única bactéria Gram-negativa estudada, enquanto que para as demais Gram-positivas o efeito de remoção foi mais pronunciado em menores concentrações de RL. A remoção dos biofilmes está relacionada com a capacidade do ramnolipídeo em penetrar na interface célula-célula e/ou célula-superfície, e uma vez adsorvido nesta interface, promove a redução da tensão interfacial. Dessa forma, a interação entre as células e a 
superfície seria reduzida e o biofilme seria mais facilmente removido (McLANDSBOROUGH et al., 2006).

\subsubsection{Análises de viabilidade celular:cinéticae influência da temperatura, meio de cultivo e concentraçãode ramnolipídeo}

O reagente resazurina foi utilizado para padronização dos ensaios de cinética de incubação tanto em células planctônicas como no biofilme e também para quantificar as células viáveis após o tratamento com o ramnolipídeo em diferentes temperaturas. Para comparar a eficiência de detecção de células metabolicamente ativas das bactérias, foi realizado inicialmente a cinética de tempo de incubação, à temperatura ambiente, tanto em células planctônicas como no biofilme, em meio de cultivo específico para cada bactéria, sem tratamento com o RL.

Os resultados para $E$. coli indicaram uma linearidade para células planctônicas em caldo nutriente (Figura 16A-A1), e com variações em leite (Figura 16A-A2). Arenas e colaboradores, (2012) encontraram resultados semelhantes para as células planctônicas de $E$. coli após a incubação à $37{ }^{\circ} \mathrm{C}$. Neste estudo, a influência do meio de cultivo também influenciou no sinal de fluorescência. Dentre os meios analisados o meio Columbia com sangue favoreceu uma taxa metabólica mais rápida para E. coli, em comparação com o mesmo meio sem sangue. A resazurina foi reduzida em diferentes taxas de acordo com a fase metabólica das bactérias, regulada pelos os componentes do meio (ARENAS; MANDEL; LILGE, 2012).

Para as células de $E$. coli no biofilme as análises mostraram que há inicialmente a presença de muitas células viáveis, visualmente perceptível pela coloração rósea do corante e altamente fluorescente. Porém durante a primeira hora de incubação houve um decaimento significativo de intensidade, passando de 200.000 para menos de 50.000 unidades arbitrárias de fluorescência (A.U.), em ambos os meios de cultivos (Figura 16B). Como o reagente não é tóxico para a bactéria, a mesma continuou apresentando atividade metabólica após 1:30 h de incubação, indicado pelo aumento de intensidade de fluorescência.Este comportamento foi evidenciado apenas no caldo nutriente (Figura 16-B1), ao contrário do leite (Figura 16-B2), onde o sinal de fluorescência continuou reduzindo. 
Figura 16- Cinética de viabilidade celular de E.coli ATCC 43895, usando o reagente resazurinaà $25^{\circ} \mathrm{C}$, em células planctônicas (A) e no biofilme (B), em caldo nutriente (A1, B1) e em leite (A2, B2).
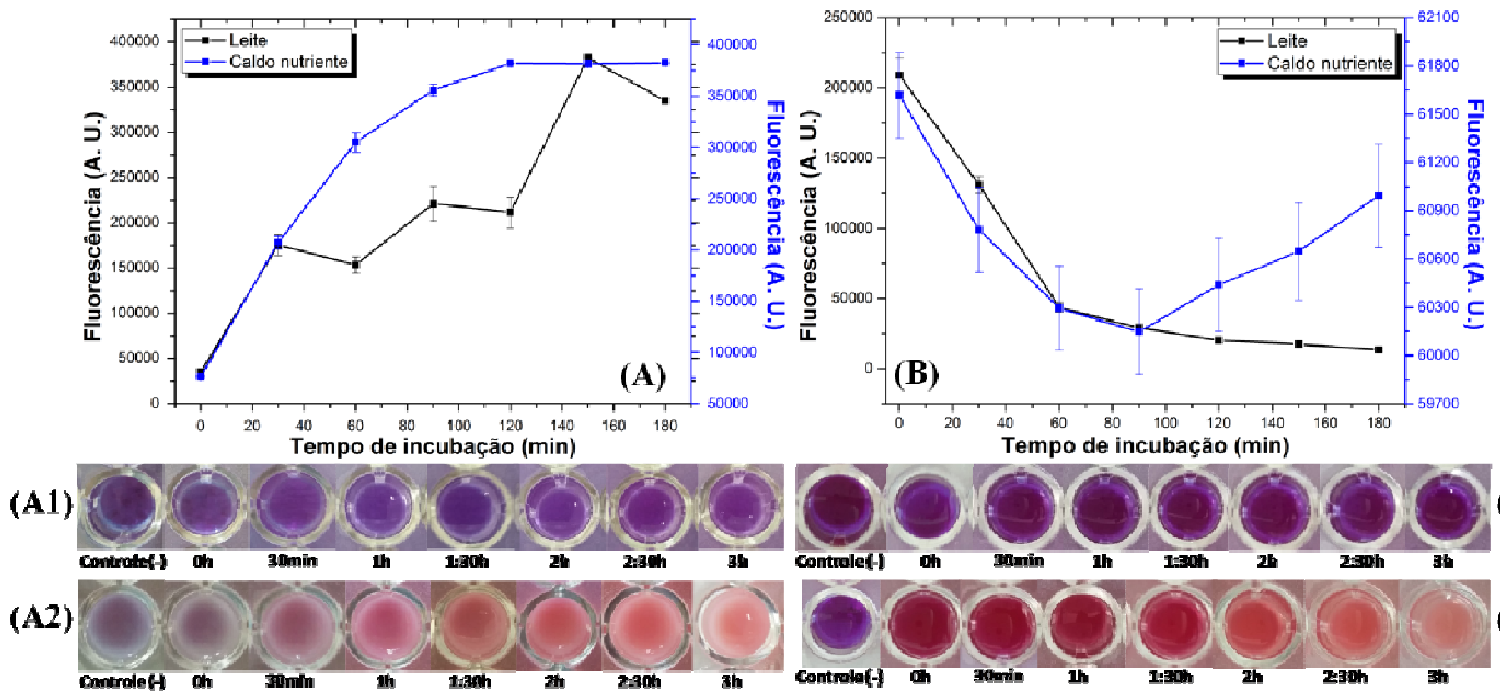

(B1)

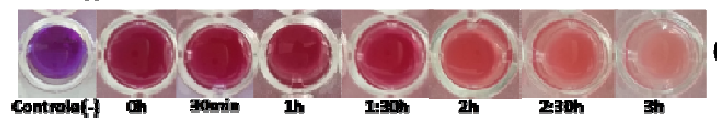

(B2)

Na Figura 17 são mostrados os resultados da cinética de $S$. aureus em células planctônicas (Figura 17A) e no biofilme (Figura 17B). Para as células planctônicas o efeito de incubação do corante resazurina foi reduzindo com o tempo tanto para o meio nutricional caldo nutriente (Figura 17-A1), como em leite (Figura 17-A2). Sendo que em leite o pico de intensidade deu-se nos primeiros $30 \mathrm{~min}$, após a primeira hora de incubação houve um rápido decaimento de metade da intensidade de sinal, de aproximadamente 16.000 para 8.000 (A.U), mantendo-se constante até o final das $3 \mathrm{~h}$ de incubação. Já os resultados de cinética para as células presentes no biofilme (Figura 17B), ocorreu o contrário, pois a intensidade de fluorescência teve aumento no decorrer do tempo para ambos os meios. Este efeito foi bem mais rápido em leite (Figura 17-B2) do que na presença do caldo nutriente (Figura 17-B1). 
Figura 17- Cinética de viabilidade celular de S. aureus ATCC 8095, usando o reagente resazurinaà $25^{\circ} \mathrm{C}$, em células planctônicas (A) e no biofilme (B), em caldo nutriente-CN (A1, B1) e em leite (A2, B2).
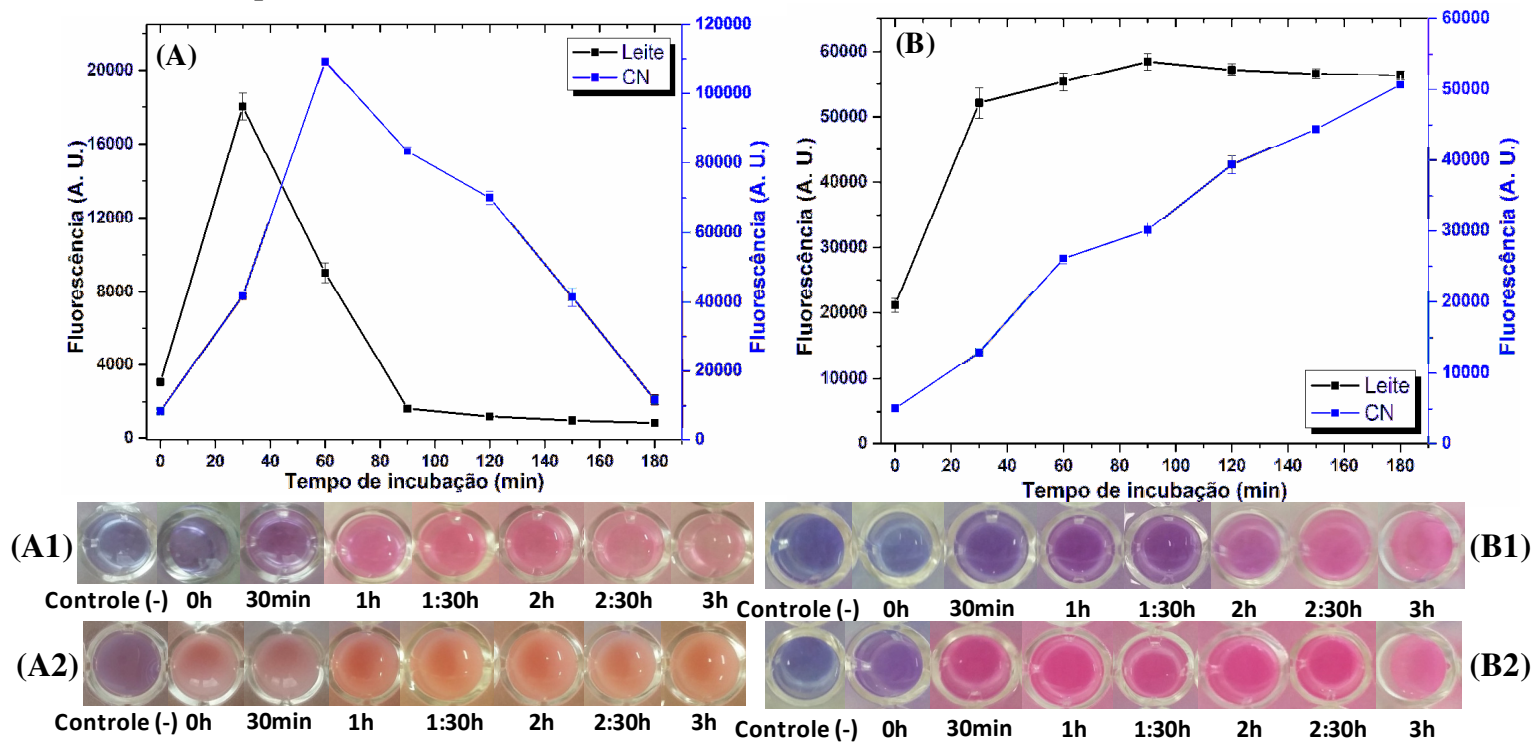

(B1)

Os estudos de cinética realizados com as células planctônicas de L. monocytogenes

(Figura 18A) mostraram um perfil semelhante ao de $S$. aureus, para ambos os meios de cultivo as células apresentaram uma redução de intensidade de fluorescência. Porém, para $L$. monocytogenesa intensidade de sinal foi bem mais elevada chegando à quase 190.000 (A.U) no pico máximo, enquanto que para S. aureus alcançou no máximo 20.000 (A.U). Essa diferença pode ter sido influenciada pela composição do meio.

Figura 18- Cinética de viabilidade celular de L. monocytogenes ATCC 19112, usando o reagente resazurinaà $25^{\circ} \mathrm{C}$, em células planctônicas (A) e no biofilme (B), em extrato de leveduracom triptona de soja TSYE (A1, B1) e em leite (A2, B2).
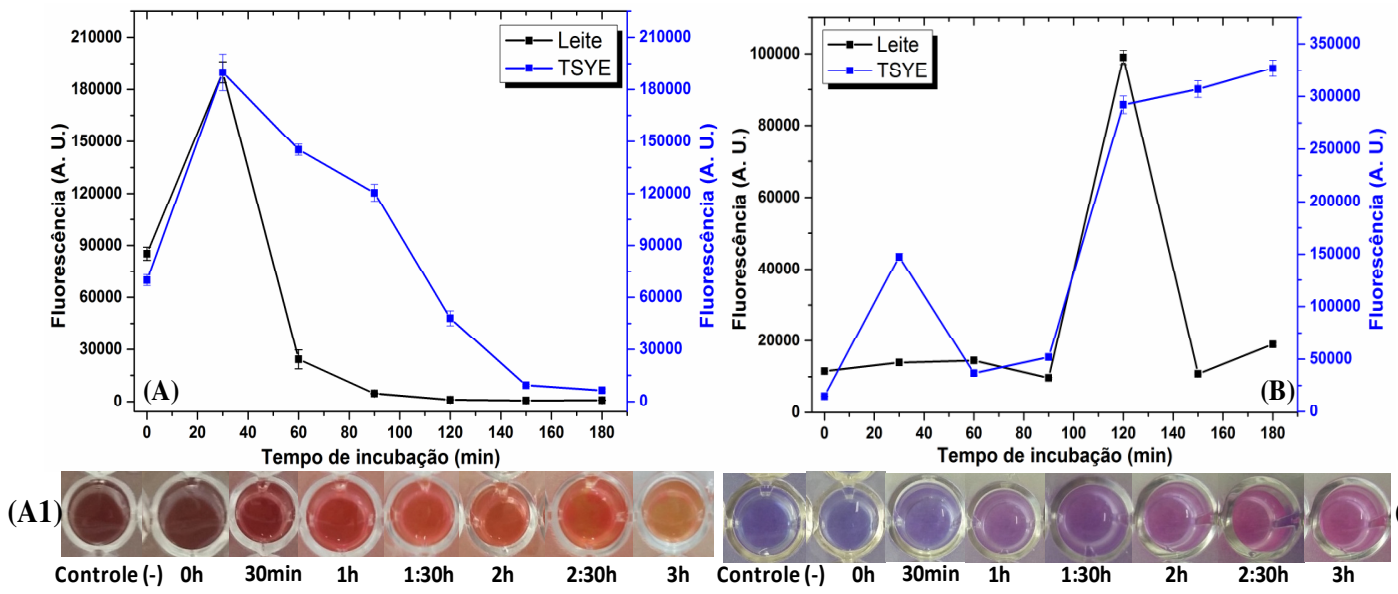

(B1)

(A2)

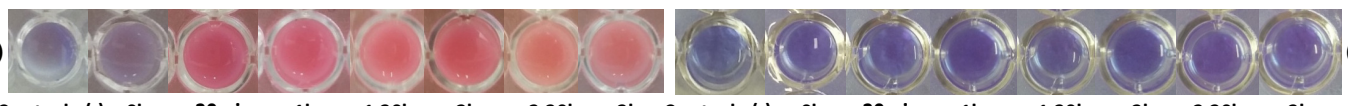


Para as células do biofilme em TSYE (Figura 19B) houve uma elevação de sinal nos primeiros $30 \mathrm{~min}$, porém após $2: 30 \mathrm{~h}$ de incubação a intensidade de fluorescência foi de 80.000 (A.U). Esse comportamento pode ser explicado pelo fato do biofilme apresentar estruturas heterogêneas, com células na superfície e também no interior, em forma de pilares e à medida que o corante penetra nesse sistema há possibilidade de encontrar mais células vivas ou não. Para as células associadas com o leite não há alteração de intensidade de sinal nos primeiros minutos, ao contrário das outras bactérias anteriormente mostradas. Isso de fato é coerente com resultados anteriores que evidenciam pouca adesão de células de $L$. monocytogenes na presença do leite. Apenas depois de $2 \mathrm{~h}$ de contato é que apresentou um pico de fluorescência, o qual chegou à 100.000 (A. U.), indicando a presença destas poucas células no biofilme.

Os resultados acima indicam que a composição do meio pode ser um fator preponderante a ser considerado durante a quantificação de viabilidade celular utilizando o corante resazurina. Estudos semelhantes realizados por Driessche et al., (2014), com células de $C$. albicans também evidenciaram que a composição do meio interfere na intensidade do sinal de fluorescência. Este fungo é geralmente cultivado em meios contendo concentrações relativamente elevadas de glicose, pelo fato de aumentar o crescimento. No entanto foi observado que o uso desse meio, rico em glicose conduzia a elevados níveis de sinal de fluorescência.

O ensaio com resazurina não requer a remoção dos biofilmes do substrato, o que evita problemas comuns encontrados durante testes tradicionais de viabilidade.Além disso é um método de quantificação rápido e de baixo custo (JIANG et al., 2011), sendo considerado útil parao estudo cinético com diferentes microrganismos e meio de cultivo para a estimativa de células metabolicamente ativas (DRIESSCHE et al., 2014).No entanto, sua desvantagem é o limite inferior de quantificação de aproximadamente $10^{6}$ UFC por biofilme (PEETERS et al., 2007).

Assim, baseando-se nestes estudos prévios de cinética de incubação, investigou-se a relação entre o número de células metabolicamente ativas e os fatores de temperatura e concentração de ramnolipídeo, após o tratamento do biofilme. Para quantificação dos biofilmes de $E$. coli em caldo nutriente e em leite (controles e tratamentos), o tempo de 
incubação com a rezasurina foi de $30 \mathrm{~min}$; para $S$. aureus tanto em caldo nutriente quanto no leite foi de $1 \mathrm{~h}$ e para L. monocytogenes para ambos os meios TSYE e leite foi de $2 \mathrm{~h}$.

A Figura 19 mostra os resultados de viabilidade para o biofilme de E. coli, após o tratamento com o ramnolipídeo por 2 h. No meio caldo nutriente (Figura 19A) a condição em que houve maior redução de células viáveis em relação ao controle foi à $25{ }^{\circ} \mathrm{C}$ na concentração de 1\% de RL, na qual diminuiu 16,6 \%, como podemos observar na Tabela 11. Já no leite o efeito de morte celular após o contato com o ramnolipídeo foi mais evidenciado nas temperaturas de 25 e $37^{\circ} \mathrm{C}$, destaque para a concentração $0,05 \%$ de RL na qual foi capaz de diminuir $60,8 \%$ (Tabela 12) de células viáveis.

Correlacionando com os dados de biomassa celular apresentados nas Figuras 14, 15 e 16, nesta concentração o ramnolipídeo não foi capaz de remover células aderidas, porém isso não impediu na sua ação antimicrobiana frente ao biofilme revelada através da mudança de coloração da resazurina. Evidenciou-se que na menor concentração, o RL foi capaz de promover a morte celular de mais de $60 \%$ do biofilme de E. coli formado em leite (Tabela 12). Isso mostra que o tratamento de RL em biofilme de $E$. coli não só promove sua remoção como também diminui sua viabilidade celular principalmente em leite, o qual foi demonstrado proporcionar uma maior adesão de células dessa bactéria.

A Figura 20 mostra os resultados de viabilidade para o biofilme de $S$. aureus, após o tratamento com o ramnolipídeo por $2 \mathrm{~h}$. Para o biofilme em caldo nutriente (Figura 20A) não houve diferença significativa em relação à cada temperatura analisada, porém observa-se que à $4{ }^{\circ} \mathrm{C}$ há uma maior redução de células viáveis quando comparado com as outras temperaturas, chegando a 58,6 \%, como podemos observar na Tabela 13. No caso dos biofilmes formados em leite (Figura 20B) o perfil de células viáveis apresenta semelhanças quando comparado ao meio caldo nutriente, não havendo diferença significativa entre as concentrações em cada temperatura analisada (Tabela 14).

Os biofilmes de L. monocytogenes mais susceptíveis ao tratamento com o ramnolipídeo foram aqueles tratados à $4^{\circ} \mathrm{C}$ para ambos os meios (Figura 21). No entanto em concentrações de ramnolipídeo diferentes, para o meio TSYE (Tabela 15) foi na concentração de $0,05 \%$ onde houve uma redução de células viáveis, em torno de $18 \%$; e no leite (Tabela 
16) a concentração de RL que apresentou maior redução de viabilidade celular foi $1 \%$, onde houve uma redução de células viáveis também de aproximadamente de $18 \%$.

Figura 19- Quantificação da viabilidade celular do biofilme formado por E.coli ATCC 43895 em caldo nutriente (A) e leite (B), após o tratamento de $2 \mathrm{~h}$ com RL. Os dados representam a média de no mínimo três repetições independentes.

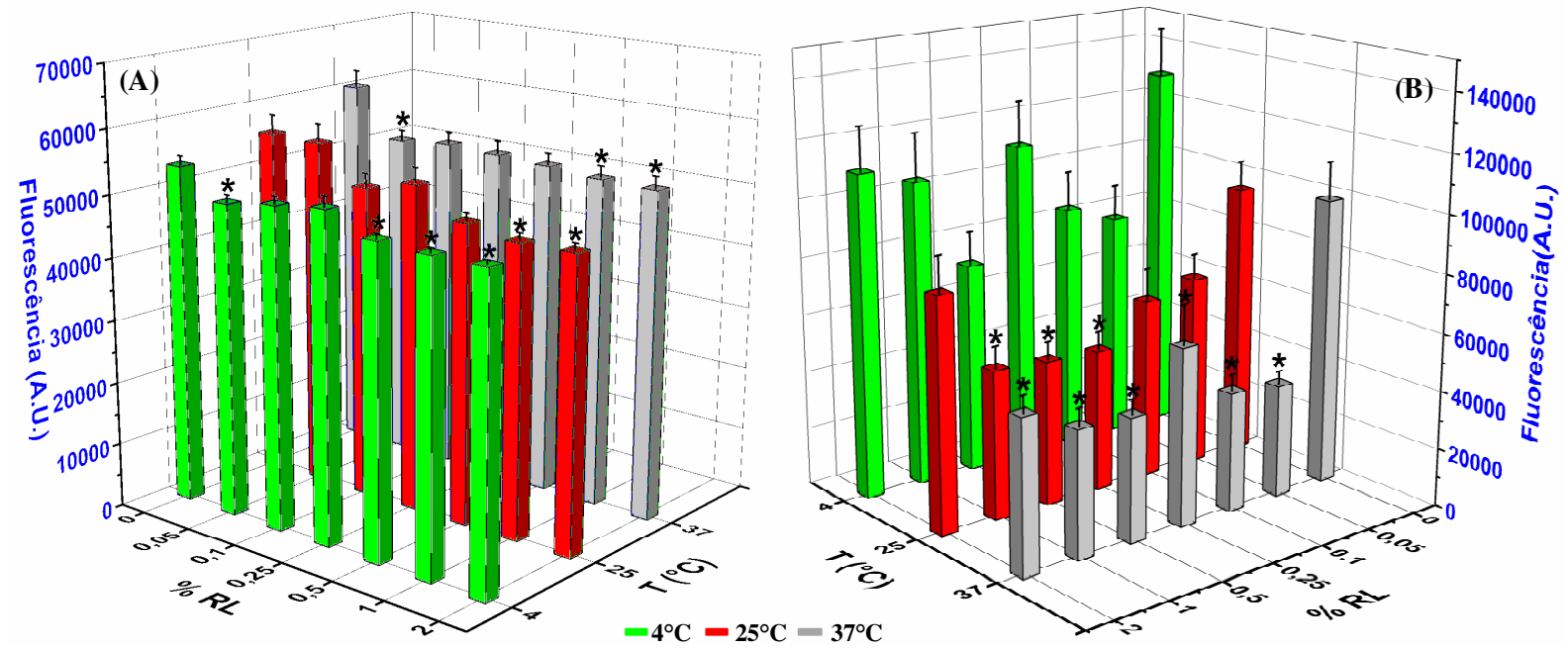

Para cada temperatura o símbolo $(*)$ significa que diferem significativamente $p<0,05$ em relação ao controle.

Tabela 11- Porcentagem de redução de células viáveis dos biofilmes E. coli ATCC 43895 em caldo nutriente $(\mathrm{CN})$, após 2 h de tratamento com RL em diferentes condições de concentração e temperatura.

\begin{tabular}{ccccc}
\hline Meio & \% RL & \multicolumn{3}{c}{ \% Redução de células viáveis* } \\
\hline & & $4^{\circ} \mathrm{C}$ & $25^{\circ} \mathrm{C}$ & $37^{\circ} \mathrm{C}$ \\
\cline { 2 - 5 } & 0,05 & $7,8^{\mathrm{A}, \mathrm{a}}$ & $0,18^{\mathrm{B}, \mathrm{a}}$ & $12,8^{\mathrm{A}, \mathrm{a}}$ \\
$\mathrm{CN}$ & 0,1 & $5,3^{\mathrm{A}, \mathrm{a}}$ & $10,1^{\mathrm{B}, \mathrm{b}}$ & $11,5^{\mathrm{B}, \mathrm{a}}$ \\
& 0,25 & $3,4^{\mathrm{A}, \mathrm{a}}$ & $6,4^{\mathrm{A}, \mathrm{b}}$ & $11,9^{\mathrm{B}, \mathrm{a}}$ \\
& 0,5 & $9,2^{\mathrm{A}, \mathrm{a}}$ & $14,3^{\mathrm{A}, \mathrm{b}}$ & $12,5^{\mathrm{A}, \mathrm{a}}$ \\
& 1 & $9,7^{\mathrm{A}, \mathrm{a}}$ & $16,6^{\mathrm{A}, \mathrm{b}}$ & $13,4^{\mathrm{A}, \mathrm{a}}$ \\
& 2 & $9,4^{\mathrm{A}, \mathrm{a}}$ & $16,2^{\mathrm{A}, \mathrm{b}}$ & $13,6^{\mathrm{A}, \mathrm{a}}$ \\
\hline
\end{tabular}

*Em cada linha os valores seguidos da mesma letra maiúscula não diferem significativamente $p<0,05$.

*Em cada coluna os valores seguidos da mesma letra minúscula não diferem significativamente $p<0,05$.

Tabela 12- Porcentagem de redução de células viáveis dos biofilmes E. coli ATCC 43895 em leite, após 2h de tratamento com RL em diferentes condições de concentração e temperatura.

\begin{tabular}{ccccc}
\hline Meio & \% RL & \multicolumn{3}{c}{ \% Redução de células viáveis } \\
\hline & & $4^{\circ} \mathrm{C}$ & $25^{\circ} \mathrm{C}$ & $37^{\circ} \mathrm{C}$ \\
\cline { 2 - 4 } & 0,05 & $38,6^{\mathrm{A}, \mathrm{a}}$ & $30,0^{\mathrm{A}, \mathrm{a}}$ & $60,8^{\mathrm{B}, \mathrm{a}}$ \\
\multirow{2}{*}{ LEITE } & 0,1 & $33,5^{\mathrm{A}, \mathrm{a}}$ & $34,3^{\mathrm{A}, \mathrm{a}}$ & $58,7^{\mathrm{B}, \mathrm{a}}$ \\
& 0,25 & $13,7^{\mathrm{A}, \mathrm{b}}$ & $48,4^{\mathrm{B}, \mathrm{a}}$ & $38,4^{\mathrm{B}, \mathrm{a}}$ \\
& 0,5 & $43,4^{\mathrm{A}, \mathrm{a}}$ & $47,4^{\mathrm{A}, \mathrm{a}}$ & $57,1^{\mathrm{B}, \mathrm{a}}$ \\
& 1 & $18,4^{\mathrm{A}, \mathrm{b}}$ & $45,9^{\mathrm{B}, \mathrm{a}}$ & $56,0^{\mathrm{C}, \mathrm{a}}$ \\
& 2 & $13,6^{\mathrm{A}, \mathrm{b}}$ & $15,2^{\mathrm{A}, \mathrm{b}}$ & $47,1^{\mathrm{B}, \mathrm{a}}$ \\
\hline
\end{tabular}

*Em cada linha os valores seguidos da mesma letra maiúscula não diferem significativamente $p<0,05$.

*Em cada coluna os valores seguidos da mesma letra minúscula não diferem significativamente $p<0,05$. 
Figura 20- Quantificação da viabilidade celular do biofilme formado por S. aureus ATCC 8095 em caldo nutriente (A) e leite (B), após o tratamento de $2 \mathrm{~h}$ com RL. Os dados representam a média de no mínimo três repetições independentes.

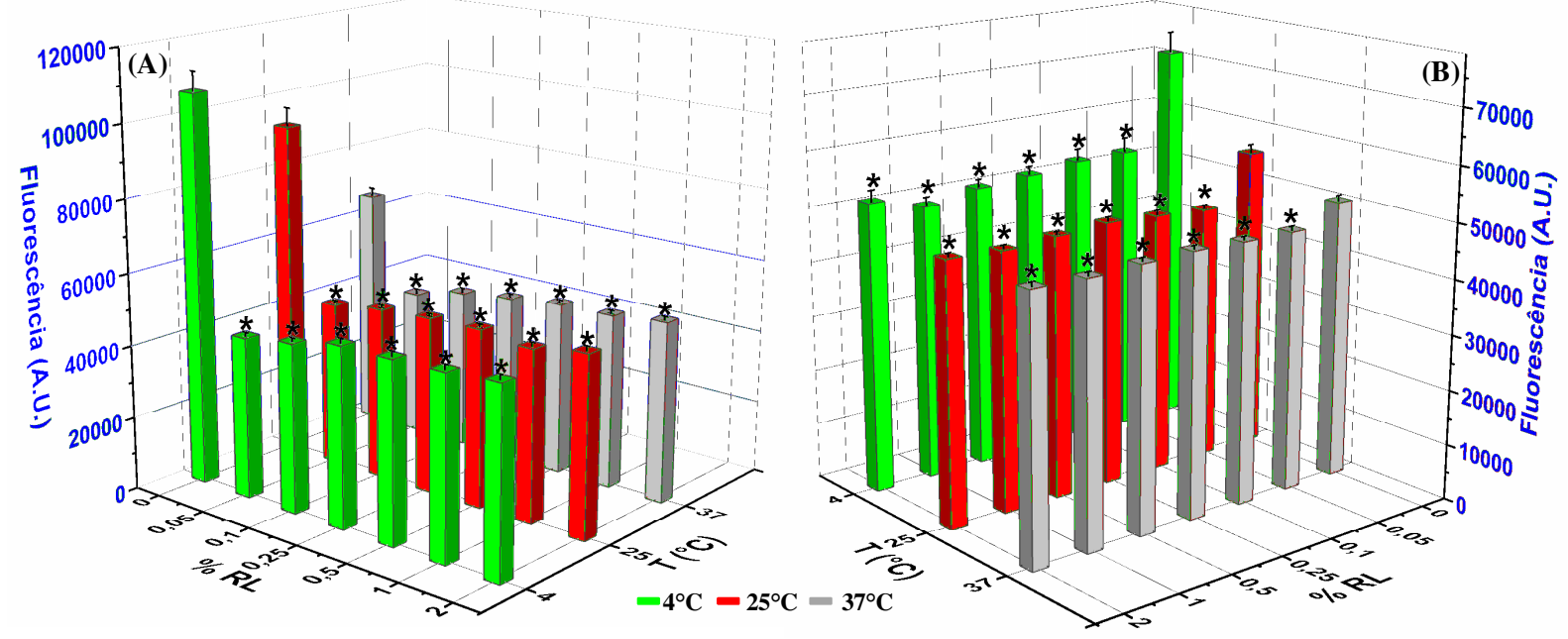

Para cada temperatura o símbolo (*) significa que diferem significativamente $p<0,05$ em relação ao controle.

Tabela 13- Porcentagem de redução de células viáveis dos biofilmes $S$. aureus ATCC 8095 formados em caldo nutriente $(\mathrm{CN})$, após $2 \mathrm{~h}$ de tratamento com RL em diferentes condições de concentração e temperatura.

\begin{tabular}{ccccc}
\hline Meio & \% RL & \multicolumn{3}{c}{ \% Redução de células viáveis* } \\
\hline & & $4^{\circ} \mathrm{C}$ & $25^{\circ} \mathrm{C}$ & $37^{\circ} \mathrm{C}$ \\
\cline { 2 - 4 } & 0,05 & $58,6^{\mathrm{A}, \mathrm{a}}$ & $51,0^{\mathrm{A}, \mathrm{a}}$ & $38,9^{\mathrm{B}, \mathrm{a}}$ \\
$\mathrm{CN}$ & 0,1 & $56,7^{\mathrm{A}, \mathrm{a}}$ & $48,8^{\mathrm{A}, \mathrm{a}}$ & $33,6^{\mathrm{B}, \mathrm{a}, \mathrm{b}}$ \\
& 0,25 & $53,7^{\mathrm{A}, \mathrm{a}}$ & $47,6^{\mathrm{A}, \mathrm{a}}$ & $30,9^{\mathrm{B}, \mathrm{b}, \mathrm{c}}$ \\
& 0,5 & $53,5^{\mathrm{A}, \mathrm{a}}$ & $47,0^{\mathrm{A}, \mathrm{a}}$ & $28,3^{\mathrm{B}, \mathrm{b}, \mathrm{c}}$ \\
& 1 & $52,9^{\mathrm{A}, \mathrm{a}}$ & $48,7^{\mathrm{A}, \mathrm{a}}$ & $27,7^{\mathrm{B}, \mathrm{b}, \mathrm{c}}$ \\
& 2 & $51,8^{\mathrm{A}, \mathrm{a}}$ & $46,0^{\mathrm{A}, \mathrm{a}}$ & $25,3^{\mathrm{B}, \mathrm{c}}$ \\
\hline
\end{tabular}

*Em cada linha os valores seguidos da mesma letra maiúscula não diferem significativamente $p<0,05$.

*Em cada coluna os valores seguidos da mesma letra minúscula não diferem significativamente $p<0,05$.

Tabela 14- Porcentagem de redução de células viáveis dos biofilmes S. aureus ATCC 8095 formados em leite, após $2 \mathrm{~h}$ de tratamento com RL em diferentes condições de concentração e temperatura.

\begin{tabular}{lcccc}
\hline Meio & \% RL & \multicolumn{3}{c}{ \% Redução de células viáveis* } \\
\hline & & $4{ }^{\circ} \mathrm{C}$ & $25^{\circ} \mathrm{C}$ & $37^{\circ} \mathrm{C}$ \\
\cline { 2 - 4 } & 0,05 & $24,8^{\mathrm{A}, \mathrm{a}}$ & $15,9^{\mathrm{B}, \mathrm{a}}$ & $6,8^{\mathrm{C}, \mathrm{a}}$ \\
\multirow{2}{*}{ LEITE } & 0,1 & $25,0^{\mathrm{A}, \mathrm{a}}$ & $14,7^{\mathrm{B}, \mathrm{a}}$ & $6,6^{\mathrm{C}, \mathrm{a}}$ \\
& 0,25 & $26,4^{\mathrm{A}, \mathrm{a}}$ & $13,6^{\mathrm{B}, \mathrm{a}}$ & $5,9^{\mathrm{C}, \mathrm{a}}$ \\
& 0,5 & $27,4^{\mathrm{A}, \mathrm{a}}$ & $14,6^{\mathrm{B}, \mathrm{a}}$ & $6,3^{\mathrm{C}, \mathrm{a}}$ \\
& 1 & $29,7^{\mathrm{A}, \mathrm{a}}$ & $15,7^{\mathrm{B}, \mathrm{a}}$ & $6,9^{\mathrm{C}, \mathrm{a}}$ \\
& 2 & $26,3^{\mathrm{A}, \mathrm{a}}$ & $14,8^{\mathrm{B}, \mathrm{a}}$ & $6,4^{\mathrm{C}, \mathrm{a}}$ \\
\hline
\end{tabular}

*Em cada linha os valores seguidos da mesma letra maiúscula não diferem significativamente $p<0,05$.

*Em cada coluna os valores seguidos da mesma letra minúscula não diferem significativamente $p<0,05$. 
Figura 21- Quantificação da viabilidade celular do biofilme formado por L. monocytogenes ATCC $19112 \mathrm{em}$ caldo TSYE (A) e leite (B), após o tratamento de $2 \mathrm{~h}$ com RL. Os dados representam a média de no mínimo três repetições independentes.

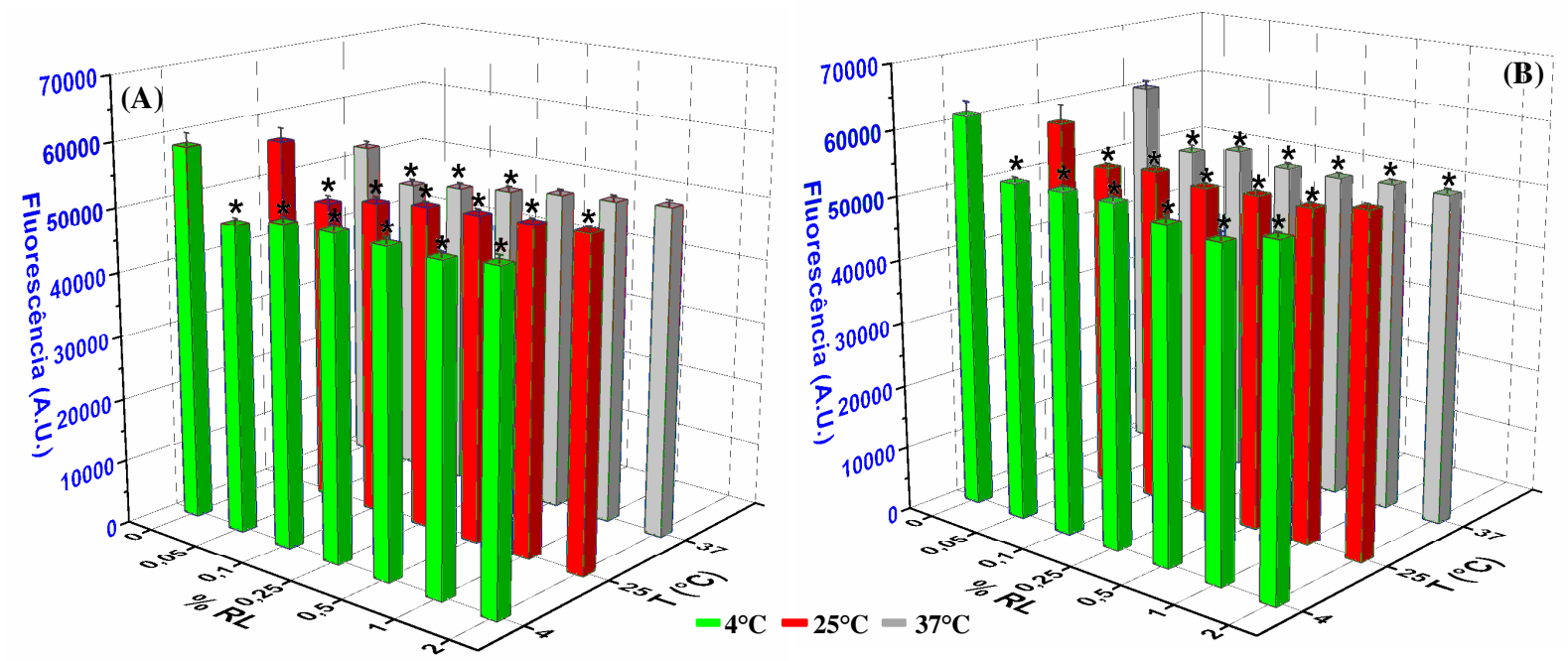

Para cada temperatura o símbolo $(*)$ significa que diferem significativamente $p<0,05$ em relação ao controle.

Tabela 15- Porcentagem de redução de células viáveis dos biofilmes L. monocytogenes ATCC 19112 formados em caldo TSYE, após $2 \mathrm{~h}$ de tratamento com RL em diferentes condições de concentração e temperatura.

\begin{tabular}{ccccc}
\hline Meio & \% RL & \multicolumn{3}{c}{ \% Redução de células viáveis* } \\
\hline & & $4^{\circ} \mathrm{C}$ & $25^{\circ} \mathrm{C}$ & $37^{\circ} \mathrm{C}$ \\
\cline { 2 - 4 } & 0,05 & $17,7^{\mathrm{A}, \mathrm{a}}$ & $14,8^{\mathrm{A}, \mathrm{a}}$ & $9,1^{\mathrm{A}, \mathrm{a}}$ \\
TSYE & 0,1 & $14,7^{\mathrm{A}, \mathrm{a}}$ & $12,1^{\mathrm{A}, \mathrm{a}}$ & $7,3^{\mathrm{A}, \mathrm{a}, \mathrm{b}}$ \\
& 0,25 & $14,1^{\mathrm{A}, \mathrm{a}}$ & $10,4^{\mathrm{A}, \mathrm{a}}$ & $5,5^{\mathrm{A}, \mathrm{a}, \mathrm{b}, \mathrm{c}}$ \\
& 0,5 & $14,5^{\mathrm{A}, \mathrm{a}}$ & $9,9^{\mathrm{A}, \mathrm{a}}$ & $3,7^{\mathrm{B}, \mathrm{b}, \mathrm{c}}$ \\
& 1 & $14,9^{\mathrm{A}, \mathrm{a}}$ & $9,4^{\mathrm{A}, \mathrm{a}}$ & $2,7^{\mathrm{B}, \mathrm{b}, \mathrm{c}}$ \\
& 2 & $13,4^{\mathrm{A}, \mathrm{a}}$ & $8,8^{\mathrm{A}, \mathrm{a}}$ & $1,4^{\mathrm{B}, \mathrm{c}}$ \\
\hline
\end{tabular}

*Em cada linha os valores seguidos da mesma letra maiúscula não diferem significativamente $p<0,05$.

*Em cada coluna os valores seguidos da mesma letra minúscula não diferem significativamente $p<0,05$.

Tabela 16- Porcentagem de redução de células viáveis dos biofilmes L. monocytogenes ATCC 19112 formados em leite, após $2 \mathrm{~h}$ de tratamento com RL em diferentes condições de concentração e temperatura.

\begin{tabular}{ccccc}
\hline Meio & \% RL & \multicolumn{3}{c}{ \% Redução de células viáveis } \\
\hline & & $4^{\circ} \mathrm{C}$ & $25^{\circ} \mathrm{C}$ & $37^{\circ} \mathrm{C}$ \\
\cline { 2 - 4 } & 0,05 & $14,2^{\mathrm{A}, \mathrm{a}}$ & $9,8^{\mathrm{A}, \mathrm{a}}$ & $15,3^{\mathrm{A}, \mathrm{a}}$ \\
LEITE & 0,1 & $13,8^{\mathrm{A}, \mathrm{a}}$ & $8,2^{\mathrm{A}, \mathrm{a}}$ & $12,7^{\mathrm{A}, \mathrm{a}}$ \\
& 0,25 & $13,8^{\mathrm{A}, \mathrm{a}}$ & $10,0^{\mathrm{A}, \mathrm{a}}$ & $14,9^{\mathrm{A}, \mathrm{a}}$ \\
& 0,5 & $16,5^{\mathrm{A}, \mathrm{a}}$ & $9,3^{\mathrm{A}, \mathrm{a}}$ & $15,0^{\mathrm{A}, \mathrm{a}}$ \\
& 1 & $17,8^{\mathrm{A}, \mathrm{a}}$ & $9,7^{\mathrm{A}, \mathrm{a}}$ & $14,2^{\mathrm{A}, \mathrm{a}}$ \\
& 2 & $14,4^{\mathrm{A}, \mathrm{a}}$ & $7,4^{\mathrm{A}, \mathrm{a}}$ & $14,3^{\mathrm{A}, \mathrm{a}}$ \\
\hline
\end{tabular}

*Em cada linha os valores seguidos da mesma letra maiúscula não diferem significativamente $p<0,05$.

*Em cada coluna os valores seguidos da mesma letra minúscula não diferem significativamente $p<0,05$. 
Os resultados de viabilidade celular (Tabela 17) apresentaram diferenças relevantes para as bactérias de estudo. Para E. coli, as células do biofilme mostraram uma maior redução de viabilidade celular em leite, em comparação ao $\mathrm{CN}$, porém nas mesmas condições de temperatura $\left(37^{\circ} \mathrm{C}\right)$. Já para os biofilmes de $S$. aureus ocorreu o contrário, o biofilme formado em $\mathrm{CN}$ apresentou maior redução de células viáveis principalmente quando tratado na temperatura de $4{ }^{\circ} \mathrm{C}$, na menor concentração de ramnolipídeo. $\mathrm{O}$ mesmo comportamento também foi observado para os resultados de viabilidade do biofilme de L. monocytogenes, nos quais a temperatura em que houve maior redução de viabilidade foi à $4{ }^{\circ} \mathrm{C}$, porém para diferentes concentrações de ramnolipídeo nos dois meios de cultivo estudados.Observa-se que em geral houve uma maior redução de células viáveis nos biofilmes das Gram-positivas frente ao tratamento com o RLà $4{ }^{\circ} \mathrm{C}$, ao passo que para a Gram-negativa esse efeito foi pronunciado em temperaturas maiores, como 25 e $37^{\circ} \mathrm{C}$.

Tabela 17- Principais resultados de redução de células viáveis dos biofilmes frente à ação de RL.

\begin{tabular}{|c|c|c|c|c|}
\hline \multirow{3}{*}{ Microrganismos } & \multicolumn{3}{|c|}{ Condições de tratamento } & \multirow[b]{2}{*}{ Redução de células viáveis (\%) } \\
\hline & Meios & $\mathbf{T}\left({ }^{\circ} \mathbf{C}\right)$ & RL (\%) & \\
\hline & $\mathrm{CN}$ & 25 & 1 & 16,6 \\
\hline E. coli & Leite & 37 & 0,05 & 60,8 \\
\hline S. aureus & $\begin{array}{c}\mathrm{CN} \\
\text { Leite }\end{array}$ & $\begin{array}{l}4 \\
4\end{array}$ & $\begin{array}{c}0,05 \\
1\end{array}$ & $\begin{array}{l}58,6 \\
29,7\end{array}$ \\
\hline L. monocytogenes & $\begin{array}{l}\text { TSYE } \\
\text { Leite }\end{array}$ & $\begin{array}{l}4 \\
4\end{array}$ & $\begin{array}{c}0,05 \\
1\end{array}$ & $\begin{array}{l}17,7 \\
17,8\end{array}$ \\
\hline
\end{tabular}

Sotirova e colaboradores, (2008), analisaram o efeito da ação do ramnolipídeo em bactérias Gram-positivas (B.subtilis) e Gram-negativas (E coli e P. aeruginosa) econstataram que em concentrações baixas, próximo à $\mathrm{CMC}(0,05 \%)$, não houve influência do crescimento para nenhuma bactéria Gram-negativa analisada. No entanto, concentrações iguais e/ou superiores à $\mathrm{CMC}$, exibiram condições tóxicas para bactéria $B$. subtilis. Devido ao fato das bactérias Gram-negativas apresentarem uma única membrana exterior contendo lipopolissacarídeo (LPS), essa estrutura promove o aumento de carga negativa da membrana celular, e a sua parte lipídica é impermeável ao ramnolipídeo. Sabe-se também que biossurfatantes aniônicos tais como o ramnolipídeo são agentes antibacterianos menos potentes do que catiônicos e anfotéricos, devido a interação repulsiva com a porção lipídica da célula bacteriana (SOTIROVA et al., 2008). 
Considerando estas informações pode-se inferir que o comportamento antimicrobiano mais pronunciado em E. coli sofre grande influência da composição do meio de cultivo favorecendo ou não o acesso do antimicrobiano à bactéria. Essas características do meio também podem alterar consideravelmente as propriedades de superfície dos biofilmes.

Quando correlaciona-se os dados de remoção e de redução de células viáveis dos biofilmes de cada microrganismos (Tabela 18) observa-se que as melhores condições de tratamento em relação à remoção são diferentes daquelas de redução de viabilidade celular. Dessa forma, os resultados mostram que a ação ramnolipídeo é bem diversificado dependendo da bactéria. Em geral nota-se que a remoção dos biofilmes foi mais expressiva em maiores temperaturas e concentrações de ramnolipídeo. Já os resultados de viabilidade mostraram-se mais sensíveis aos tratamentos em menores temperaturas e concentrações de ramnolipídeo.

Tabela 18-Relação entre os principais resultados de remoção da biomassa celular com os resultados de redução de viabilidade celular de todas as bactérias de estudo frente à ação do ramnolipídeo (RL).

\begin{tabular}{|c|c|c|c|c|c|c|c|}
\hline \multirow[b]{2}{*}{ Microrganismos } & \multirow[b]{2}{*}{$\begin{array}{l}\text { Meios } \\
\text { de } \\
\text { cultivo }\end{array}$} & \multicolumn{2}{|c|}{$\begin{array}{l}\text { Condições de } \\
\text { tratamento }\end{array}$} & \multicolumn{4}{|c|}{$\begin{array}{c}\text { Condições de } \\
\text { tratamento }\end{array}$} \\
\hline & & $\begin{array}{c}\mathbf{T} \\
\left({ }^{\circ} \mathbf{C}\right)\end{array}$ & $\begin{array}{c}\text { RL } \\
(\%)\end{array}$ & $\begin{array}{c}\text { Remoção da } \\
\text { biomassa celular } \\
(\%)\end{array}$ & $\begin{array}{c}\mathbf{T} \\
\left({ }^{\circ} \mathbf{C}\right)\end{array}$ & $\begin{array}{l}\text { RL } \\
(\%)\end{array}$ & $\begin{array}{c}\text { Redução de } \\
\text { células viáveis } \\
(\%)\end{array}$ \\
\hline \multirow[t]{2}{*}{ E. coli } & $\mathrm{CN}$ & 25 & 2 & 33,3 & 25 & 1 & 16,6 \\
\hline & Leite & 37 & 2 & 80 & 37 & 0,05 & 60,8 \\
\hline \multirow[t]{2}{*}{ S. aureus } & $\mathrm{CN}$ & 25 & 0,1 & 34,7 & 4 & 0,05 & 58,6 \\
\hline & Leite & 4 & 0,05 & 88,9 & 4 & 1 & 29,7 \\
\hline \multirow[t]{2}{*}{ L. monocytogenes } & TSYE & 37 & 0,5 & 35,3 & 4 & 0,05 & 17,7 \\
\hline & Leite & 4 & 0,5 & 63,6 & 4 & 1 & 17,8 \\
\hline
\end{tabular}

\subsection{Caracterização dos biofilmes antes e após o tratamento com ramnolipídeo}

\subsubsection{Análise da molhabilidade}

A fixação bacteriana a uma superfície inerte resulta de interações físico-químicas complexas entre as células, a superfície, e a fase líquida. Essas interações são mediadas por algumas propriedades, como: carga da superfície da célula, a hidrofobicidade, e aceitadores e doadores de elétrons.O ângulo de contato com a água fornece informações sobre o grau de hidrofobicidade da superfície. O termo sólido hidrofílico denota o sólido que é completamente molhável pela água ou solução aquosa, enquanto sólido hidrofóbico denota uma 
molhabilidade parcial do mesmo pela fase aquosa. Segundo Daltin, 2011 o sólido se mostrará completamente molhado pelo líquido se o ângulo de contato for zero, e somente parcialmente molhado se o ângulo de contato tiver valor finito.

De acordo com este critério, a superfície de poliestireno estudada foi considerada hidrofóbica, pois apresentou um ângulo de $83,51^{\circ}$, como podemos observar nas Tabelas abaixo. Porém, quando a mesma foi submetida ao crescimento de biofilmes, a superfície apresentou perfis totalmente diferentes dependendo da bactéria e das condições de tratamento nas quais foram submetidas. Para o biofilme de E. coli (Tabela 19) formado em caldo nutriente, a superfície apresentou uma redução de hidrofobiciadade, pois o ângulo de contato com água diminuiu para 63,51․ Após o tratamento com o ramnolipídeo houve uma considerável redução do ângulo entre a superfície sólida e o ar, quando comparado com o controle, tornando a superfície menos hidrofóbica $\left(20,62^{\circ}\right)$. Já quando o biofilme foi submetido ao crescimento em leite, houve um ligeiro aumento do ângulo para $71,93^{\circ}$ nas amostras controles, porém após o tratamento com ramnolipídeo permaceu equivalenteao tratamento do $\mathrm{CN}$, em torno de $21,55^{\circ}$

Tabela 19- Medidas dos ângulos de contato da superfície dos biofilmes de E. coli ATCC 43895 antes e após o tratamento com o ramnolipídeo.

\begin{tabular}{|c|c|c|c|c|}
\hline Amostras & $\begin{array}{l}\text { Meio de } \\
\text { cultivo }\end{array}$ & $\begin{array}{l}\text { Temperatura de } \\
\text { tratamento }\left({ }^{\circ} \mathrm{C}\right)\end{array}$ & $\begin{array}{c}\text { Concentração } \\
\text { de RL }(\%)\end{array}$ & $\begin{array}{c}\text { Ângulo } \\
\text { de contato }\left({ }^{\circ}\right)^{*}\end{array}$ \\
\hline Poliestireno & - & - & - & $83,51 \pm 2,94$ \\
\hline Controle & $\mathrm{CN}$ & 25 & $0 * *$ & $63,51 \pm 4,43$ \\
\hline Tratamento & $\mathrm{CN}$ & 25 & 2 & $20,62 \pm 3,90$ \\
\hline Controle & Leite & 37 & $0 * *$ & $71,93 \pm 3,47$ \\
\hline Tratamento & Leite & 37 & 2 & $21,55 \pm 2,05$ \\
\hline
\end{tabular}

*Média de no mínimo 6 gotas \pm desvio padrão

**Os controles foram tratadoscom água destilada esterilizada

Para o biofilme de S. aureus (Tabela 20) formado em caldo nutriente, a superfície também reduziu sua hidrofobicidade, pois o ângulo de contato com água diminuiu para $58,22^{\circ}$, no controle. Após o tratamento com o ramnolipídeo houve uma expressiva redução do ângulopara $12,27^{\circ}$ quando comparado com o controle, tornando a superfície menos hidrofóbica (hidrofílica). Em relação ao biofilme formado em leite o ângulo de contato 
apresentado foi de $35,35^{\circ}$ para o controle e de $14,61^{\circ}$ após o tratamento. Porém também apresentou carácter de superfície hidrofílica.

Tabela 20- Medidas dos ângulos de contato da superfície dos biofilmes de $S$. aureus ATCC 8095 antes e após o tratamento com o ramnolipídeo.

\begin{tabular}{ccccc}
\hline Amostras & $\begin{array}{c}\text { Meio de } \\
\text { cultivo }\end{array}$ & $\begin{array}{c}\text { Temperatura de } \\
\text { tratamento }\left({ }^{\circ} \mathbf{C}\right)\end{array}$ & $\begin{array}{c}\text { Concentração } \\
\text { de RL }(\%)\end{array}$ & $\begin{array}{c}\text { Ângulo } \\
\text { de contato }\left({ }^{\circ}\right)^{*}\end{array}$ \\
\hline Poliestireno & - & - & - & $83,51 \pm 2,94$ \\
& & & & \\
Controle & $\mathrm{CN}$ & 25 & 0,1 & $58,22 \pm 6,64$ \\
Tratamento & $\mathrm{CN}$ & 25 & & $12,27 \pm 5,57$ \\
& & & $0 * 05$ & $35,35 \pm 6,68$ \\
Controle & Leite & 4 & 0,05 & $14,61 \pm 4,87$ \\
Tratamento & Leite & 4 & &
\end{tabular}

*Média de no mínimo 6 gotas \pm desvio padrão

**Os controles foram tratadoscom água destilada esterilizada

Para o biofilme de L. monocytogenes (Tabela 21) formado em meio TSYE foi obtido um ângulo de contato de 7,67 para o controle. E após o tratamento com $0,5 \%$ de ramnolipídeo o ângulo de contato reduziu para $3,79^{\circ}$, o que mostra o caráter altamente hidrofílico pois o ângulo formado entre a superfíce e a água foi próximo à $0^{\circ}$. Para o biofilme formado em leite o comportamento foi um pouco diferente, no controle foi obtido um ângulo de $43,23^{\circ}$, e após o tratamento o ângulo diminuiu para apenas $5,82^{\circ}$, o que representa também maior facilidade de molhabilidade dessa superfície.

Tabela 21- Medidas dos ângulo de contato da superfície dos biofilmes de L. monocytogenes ATCC 19112 antes e após o tratamento com o ramnolipídeo.

\begin{tabular}{ccccc}
\hline Amostras & $\begin{array}{c}\text { Meio de } \\
\text { cultivo }\end{array}$ & $\begin{array}{c}\text { Temperatura de } \\
\text { tratamento }\left({ }^{\circ} \mathbf{C}\right)\end{array}$ & $\begin{array}{c}\text { Concentração } \\
\text { de RL }(\%)\end{array}$ & $\begin{array}{c}\text { Ângulo } \\
\text { de contato }\left({ }^{\circ}\right)^{*}\end{array}$ \\
\hline Poliestireno & - & - & - & $83,51 \pm 2,94$ \\
Controle & TSYE & 37 & $0 * *$ & $7,67 \pm 1,24$ \\
Tratamento & TSYE & 37 & 0,5 & $3,79 \pm 1,21$ \\
& & & & \\
Controle & Leite & 4 & $0,5 *$ & $43,23 \pm 7,97$ \\
Tratamento & Leite & 4 & & $5,82 \pm 2,62$ \\
\hline
\end{tabular}

*Média de no mínimo 6 gotas \pm desvio padrão

**Os controles foram tratadoscom água destilada esterilizada

A Figura 22 ilustra as gotas de água sobre a superfície de poliestireno sem formação de biofilme (Figura 22-A) e com a formação de biofilme nos diferentes meios de cultivo 
utilizados: caldo nutriente representado na Figura 22-B, extrato de levedura com triptona de soja na Figura 22-C, leite na Figura 22-D, e a Figura 22-E representa uma imagem do biofilme formado em poliestireno após o tratamento com ramnolipídeo. Através dessas imagens pode-se observar que houve uma nítida redução do ângulo de contato entre as superfícies analisadas, antes mesmo do tratamento com o ramnolipídeo. Porém, quando compara-seos biofilmes formados em meios comercias e o leite, o meio extrato de levedura com triptona de soja apresentou uma maior redução da hidrofobicidade, em relação ao controle (apenas poliestireno) e com o tratamento com RL esse efeito foi mais pronunciado. Isso resulta em uma maior molhabilidade da superfície de estudo, uma propriedade importante para indústria de alimentos que procura um agente tensoativo com essa capacidade de remoção de biofilmes.

Figura 22- Imagens ilustrativas das gotas de água sobre a superfície de poliestireno. Onde (A) representa apenas o poliestireno sem biofilme; (B) poliestireno+ biofilme formados na presença do meio caldo nutriente; (C) poliestireno+ biofilme formados em meio extrato de levedura com triptona de soja; (D) poliestireno+ biofilme formados em leite e (E) poliestireno+ biofilme após o tratamento com ramnolipídeo.

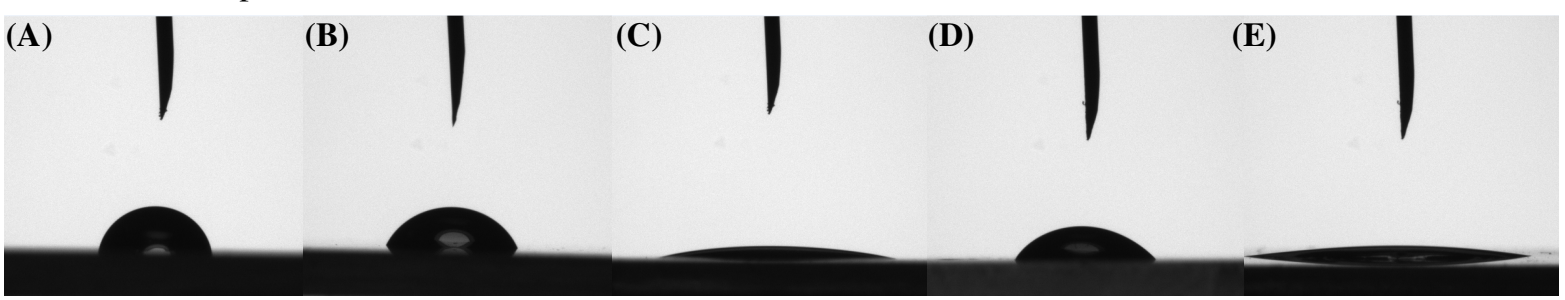

Em geral a superfície de poliestireno recoberta por biofilme apresentou uma redução da hidrofobicidade em relação ao controle, como é observadonas imagens registradas durante as medidas do ângulo de contato (Figura 22). Porém é notável a diferença entre os meios de cultivo utilizados para o seu crescimento, indicando que a composição é um fator importante a ser avaliado.

No caso específico do leite vários trabalhos relataram que seus componentes podem alterar as propriedades da superfície (DAT et al., 2010; SZLAVIK et al, 2012.). Yang et al., (1991) analisaram a adsorção da proteína $\beta$-lactoglobulina pelo método do ângulo de contato em diferentes materiais constatando que superfícies hidrofóbicas tornaram-se mais hidrofílicas. Rubio et al., (2002) relataram que a adsorção da proteína albumina de soro bovino (BSA), conduziu à variações importantes nas características de superfícies de aço 
inoxidável. Szlavik et al., (2012) demonstraram que o caráter hidrofílico da superfície aumentou após o revestimentodo vidro com leite homogeneizado.

Em geral pode-se correlacionar o caráter hidrofílico com as altas concentrações de polissacarídeos e as baixas concentrações de compostos hidrocarbonados na superfície celular (LY et al., 2006). Estudos indicam que as linhagens com maior capacidade de produzir exopolissacarídeos (EPS), provavelmente são as menos hidrofóbicas e possuem maior capacidade de formar biofilmes (MEYLHEUC et al., 2006).

\subsubsection{Análise da matriz polimérica extracelular}

Uma das principais características da formação de biofilme é a produção de uma matriz extracelular composta por $90 \%$ de água e $10 \%$ de substâncias poliméricas extracelulares (EPS) (FLEMMING; WINGENDER, 2010). Os componentes do EPS ajudama mediar a maior parte das interações célula-a-célula e célula-surperfície que são necessárias para a formação e estabilização das colônias no biofilme. Os componentes estruturais da matriz incluem proteínas de superfície celular, pili proteicos, DNA, RNA, lipídios e polissacarídeos (FLEMMING; WINGENDER, 2010). Diante disso, neste trabalho quantificou-se carboidratos, proteínas e DNA extracelular para cada bactéria de estudo antes e após o tratamento com o ramnolipídeo.

A Tabela 22 apresenta os resultados da quantificação de carboidratos, proteínas totais e DNA extracelular da matriz do biofilme de E. coli ATCC 43895, avaliado em 24 h, e $S$. aureus ATCC 8095 e L. monocytogenes ATCC 19112 avaliados em 48 h. Para os biofilmes de $E$. coli cultivados em caldo nutriente observa-se que após o tratamento com o ramnolipídeo houve um aumento das concentrações de carboidratos e DNA e diminuição de proteínas totais. Em meio de cultivo leite também foi observado o mesmo comportamento. Já para os biofilmes de $S$. aureus formados tanto em caldo nutriente como em leite foi observado uma diminuição de concentração de todas as biomoléculas analisadas em relação ao controle sem tratamento com o ramnolipídeo.

L. monocytogenes foi o microrganismo que apresentou a maior concentração de carboidratos tanto no controle como após o tratamento com ramnolipídeo. Como observado 
anteriormente esse microrganismo apresentou grande capacidade de formar biofilmes, principalmente em meio TSYE. Resultados semelhantes foram encontrados por CHAE e colaboradores (2006), no qual concluíram que quanto maiores os níveis de carboidratos extracelulares produzidos por diferentes linhagens de L. monocytogenes, maiores foram sua capacidade em formar biofilmes. Borucki et al., (2003) também mostrou que quanto maior produção de exopolissacarídeos em linhagens de L. monocytogenes maior foi adesão na superfície de estudo. No entanto, a concentração de carboidratos mais expressiva foi no biofilme de $S$. aureus formado em leite com $5,48 \mu \mathrm{g} / \mathrm{mg}_{\text {biof }}$, confirmando que as cepas que são capazes de sintetizar e exportar exopolissacarídeos geralmente exibem maior adesão, aumenta a formação de biofilme, e diminue a sensibilidade à morte por biocidas.

Tabela 22- Quantificação de carboidratos, proteínas e DNA extracelular presentes na matriz polimérica extracelular dos diferentes biofilmes estudados.

\begin{tabular}{|c|c|c|c|c|c|c|}
\hline Microrganismos & $\begin{array}{c}\text { Meios de } \\
\text { cultivo/amostra }\end{array}$ & $\mathbf{T}\left({ }^{\circ} \mathbf{C}\right)$ & RL (\%) & $\begin{array}{c}\text { Carboidratos* } \\
\left(\mu \mathrm{g} / \mathrm{mg}_{\text {biof }}\right)\end{array}$ & $\begin{array}{l}\text { Proteínas* } \\
\left(\mu \mathrm{g} / \mathrm{mg}_{\text {biof }}\right)\end{array}$ & $\begin{array}{c}\text { DNA* } \\
\left(\mu \mathrm{g} / \mathrm{mg}_{\text {biof }}\right) \times 10^{-3}\end{array}$ \\
\hline \multirow{4}{*}{$\begin{array}{c}\text { E. coliATCC } \\
43895\end{array}$} & CN/Controle & 25 & $0 * *$ & $0,12 \pm 0,14$ & $0,12 \pm 0,02$ & $5,50 \pm 0,02$ \\
\hline & $\mathrm{CN} /$ Tratamento & 25 & 2 & $1,74 \pm 0,31$ & $0,07 \pm 0,04$ & $22,8 \pm 15,27$ \\
\hline & Leite/Controle & 37 & $0 * *$ & $0,66 \pm 0,75$ & $0,50 \pm 0,06$ & $10,50 \pm 9,19$ \\
\hline & Leite/Tratamento & 37 & 2 & $1,39 \pm 1,23$ & $0,29 \pm 0,03$ & $10,00 \pm 2,80$ \\
\hline \multirow{4}{*}{$\begin{array}{c}\text { S. aureus ATCC } \\
8095\end{array}$} & CN/Controle & 25 & $0 * *$ & $0,22 \pm 0,00$ & $1,35 \pm 0,57$ & $137,00 \pm 0,02$ \\
\hline & CN/Tratamento & 25 & 0,1 & $0,16 \pm 0,03$ & $0,65 \pm 0,38$ & $15,00 \pm 0,01$ \\
\hline & Leite/Controle & 4 & $0 * *$ & $5,48 \pm 0,11$ & $1,67 \pm 0,48$ & $100,00 \pm 0,02$ \\
\hline & Leite/Tratamento & 4 & 0,05 & $0,56 \pm 0,02$ & $0,73 \pm 0,88$ & $7,00 \pm 0,02$ \\
\hline \multirow{4}{*}{$\begin{array}{l}\text { L. monocytogenes } \\
\text { ATCC } 19112\end{array}$} & TSYE/Controle & 37 & $0 * *$ & $1,30 \pm 1,16$ & $0,45 \pm 0,03$ & $25,75 \pm 10,25$ \\
\hline & TSYE/Tratamento & 37 & 0,5 & $0,72 \pm 0,85$ & $0,42 \pm 0,07$ & $15,50 \pm 13,43$ \\
\hline & Leite/Controle & 4 & $0 * *$ & $1,68 \pm 2,22$ & $0,74 \pm 0,11$ & $12,75 \pm 10,25$ \\
\hline & Leite/Tratamento & 4 & 0,5 & $0,28 \pm 0,27$ & $0,25 \pm 0,04$ & $20,10 \pm 23,19$ \\
\hline
\end{tabular}

*Os valores correspondem às médias de três experimentos independentes.

**Os controles foram tratados com água destilada esterilizada. 


\subsubsection{Avaliação morfológica dos biofilmes}

\subsubsection{Microcopia Eletrônica de Varredura}

As análises de Microscopia Eletrônica de Varredura (MEV) ilustram a morfologia dos biofilmes formados em poliestireno, pelas bactérias E. coli, S. aureus e L. monocytogenes antes e após a ação do ramnolipídeo em meios nutricionais Caldo nutriente, Extrato de levedura com triptona de soja e leite.

$\mathrm{Na}$ Figura 23 observa-se a formação dos biofilmes de E. coli (ATCC 43895) formados por $24 \mathrm{~h}$ à $37^{\circ} \mathrm{C}$, em caldo nutriente (Figura $23 \mathrm{~A} \mathrm{e} \mathrm{B}$ ) e leite (Figura $23 \mathrm{C}$ e D). Como evidenciado em experimentos anteriores, E. coli forma menos biofilme em caldo nutriente e consequentemente não houve adesão tão expressiva na superfície de poliestireno (Figura 23 A). No entanto quando na presença do leite as células apresentaram maior adesão ao poliestireno (Figura $23 \mathrm{~B}$ ). Esse comportamento revela que o tipo de meio nutritivo pode ter favorecido a maturidade do biofilme. Essa característica é proporcionada pelo aumento da densidade da população de células, bem como da produção e deposição de polímeros extracelulares, o que favorece o aumento do biofilme (OLIVEIRA et al, 2010). 
Figura 23- Eletromicrografias dos biofilmes de E.coli ATCC 43895 em caldo nutriente,(A) Controle, (B) Tratado com $2 \%$ de RL à $25{ }^{\circ} \mathrm{C}$ e em leite (C) Controle e (D) Tratado com $2 \%$ de RL à $37{ }^{\circ} \mathrm{C}$. Aumento $2.000 \mathrm{X}$.
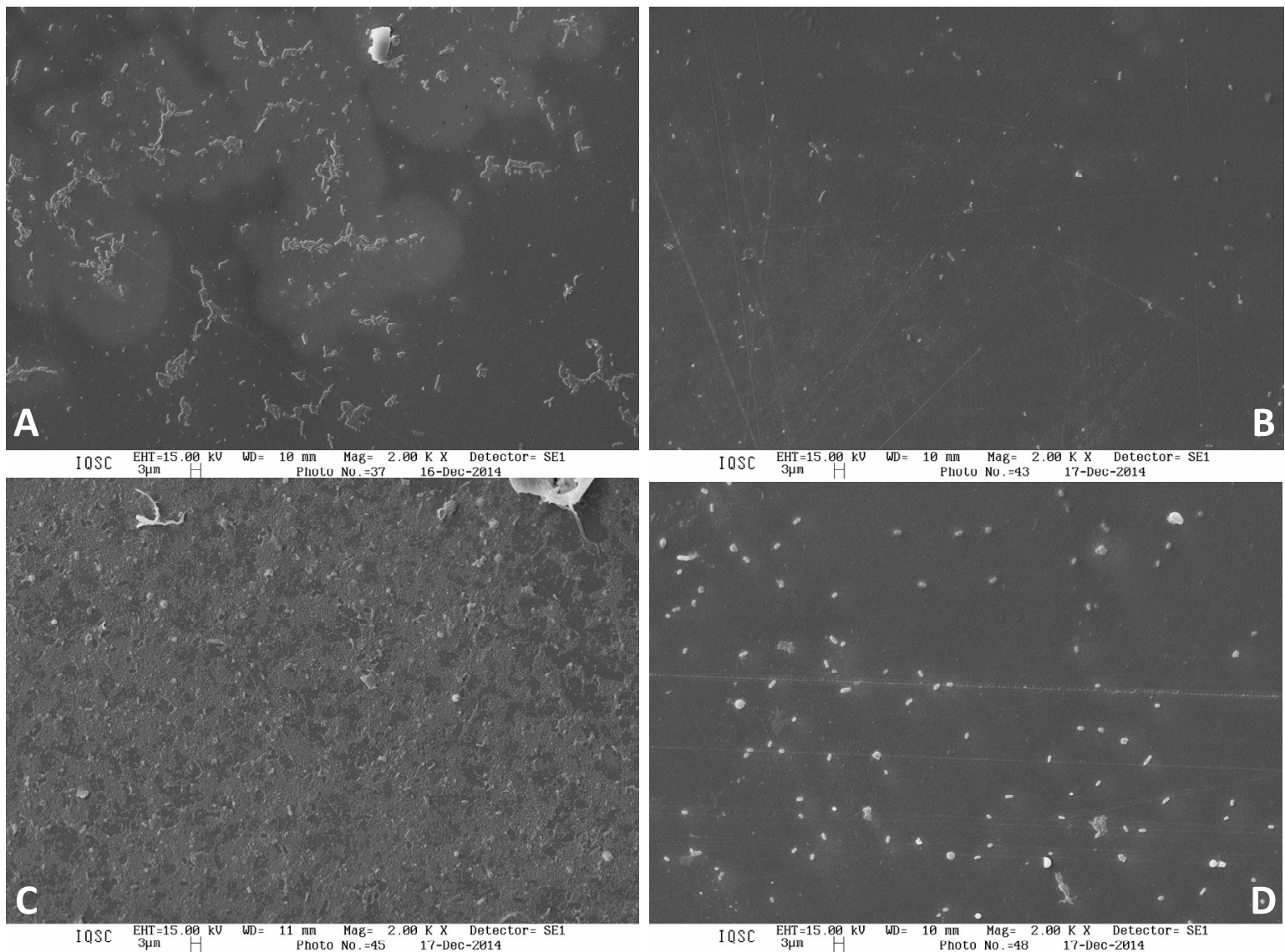

As micrografias dos biofilmes de $S$. aureus sobre superfície de poliestireno mostram que as células apresentam capacidade de formar biofilmes tanto em caldo nutriente (Figura 24A e B) quanto em leite (Figura 24C e D), como podemos observar abaixo. Após 48 h de incubação formou-se um biofilme bem espesso com morfologias diferenciadas para os meios analisados. No leite por exemplo há uma aparente predominância de agregados bacterianos, enquanto que no caldo nutriente isso não foi observado. Porém em ambos os biofilmes há a presença de MPE . E com a adição do ramnolipídeo, por um período de apenas $2 \mathrm{~h}$ sobre o biofilme foi possível notar a redução da MPE e das bactérias aderidas em superfície de poliestireno na presença dos dois meios de cultivo, demonstrando a ação do RL. 
Figura 24- Eletromicrografias dos biofilmes de $S$. aureus ATCC 8095 em caldo nutriente, onde (A) é o controle, (B) o tratado com $0,1 \%$ de RL à $25^{\circ} \mathrm{C}$ e em leite, onde (C) é o controle e (D) tratado com $0,05 \%$ de RL à $4{ }^{\circ} \mathrm{C}$. Aumento de $10.000 \mathrm{X}$.
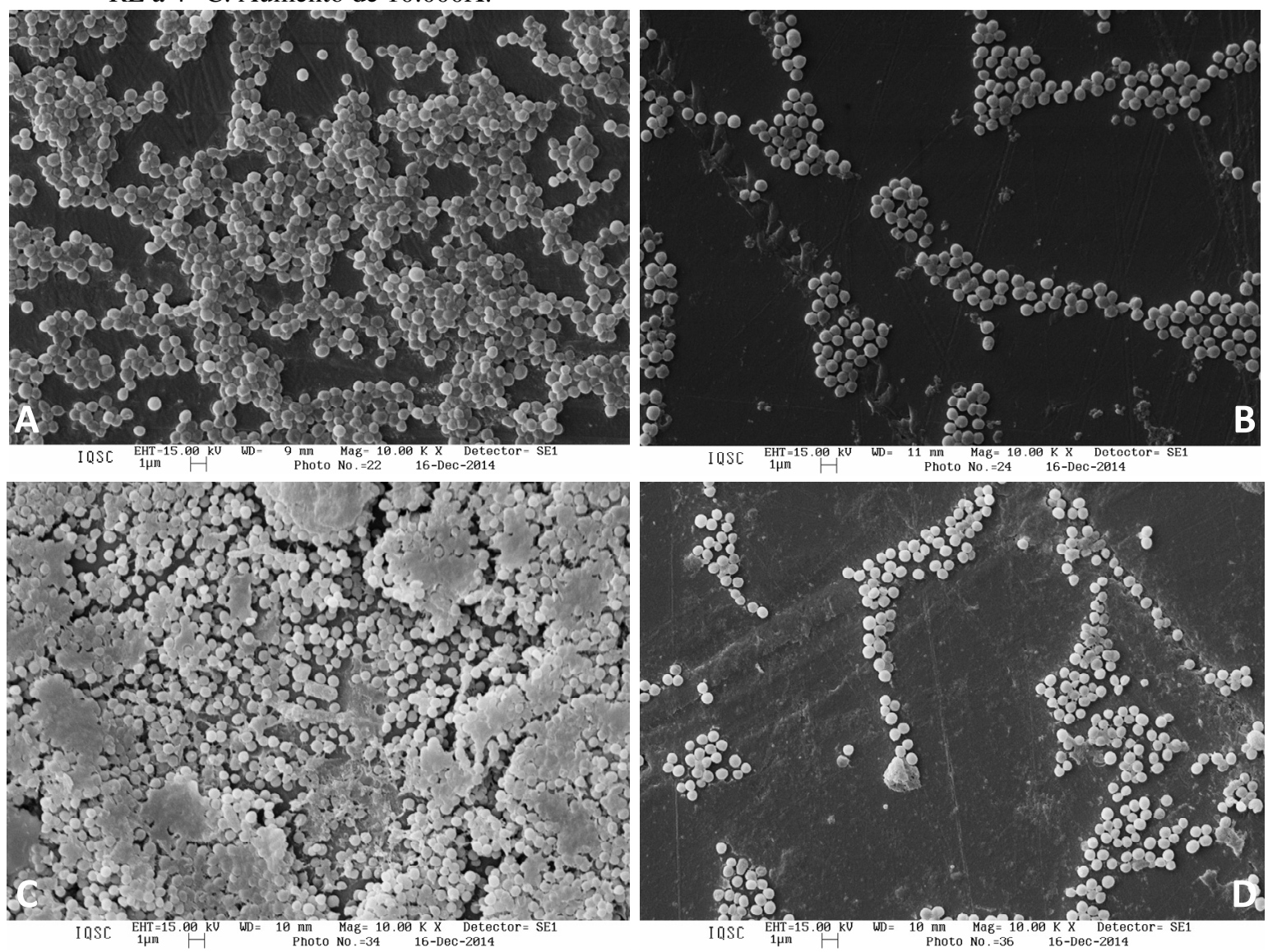

A Figura 25 mostra o biofilme de L. monocytogenes formado em TSYE (Figura 25A e B) e em leite (Figura 25C e D) antes e após o tratamento com ramnolipídeo, nas concentrações de $0,5 \%$ à $37{ }^{\circ} \mathrm{C}$ e à $4{ }^{\circ} \mathrm{C}$, respectivamente. Após o período de incubação por $48 \mathrm{~h}$ observou-se a formação de um biofilme com grande produção de polímero extracelular, apenas no substrato TSYE. Com a adição do ramnolipídeo sobre o biofilme foi possível observar a redução da matriz polimérica e de grande parte das bactérias aderidas, demonstrando sua eficiente ação. 
Figura 25- Eletromicrografias dos biofilmes de L. monocytogenes ATCC 19112 formados em Extrato de levedura com triptona de soja, sendo (A) o controle e (B) o tratamento com $0,5 \%$ de RL à $37^{\circ} \mathrm{C}$ (Aumento de 10.000X) e em leite, sendo (C) o controle e (D) o tatamento com $0,5 \%$ de RL à $4{ }^{\circ} \mathrm{C}$ (Aumento de 2.000X).
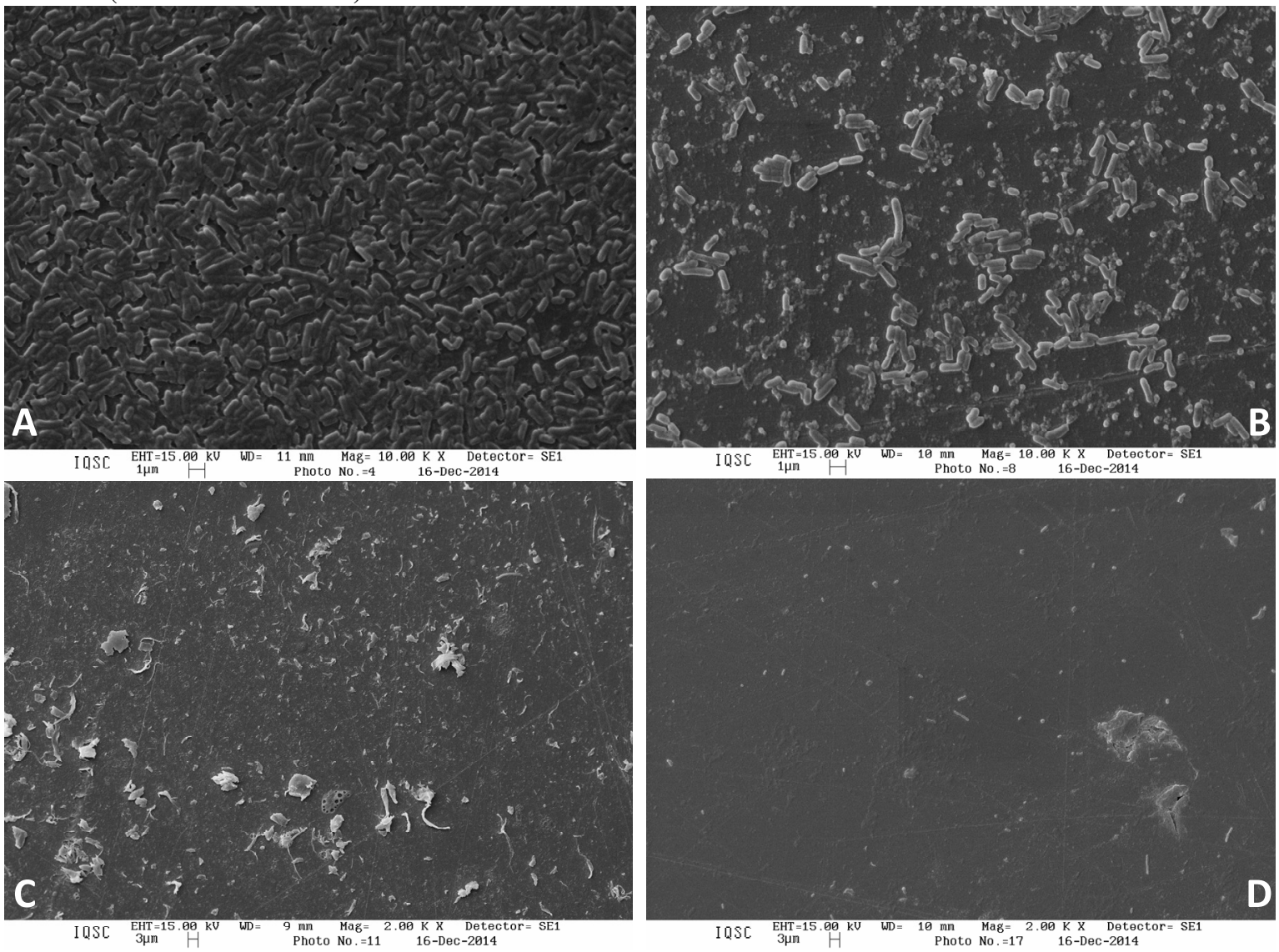

A formação de biofilme é um processo complexo regulado por diversos fatores, incluindo o meio de crescimento e portanto ainda é pouco entendido, principalmente em matriz alimentar (MARCHAND et al., 2012). O leite é um meio bastante heterogêneo, compreende em uma mistura de vários tipos de proteínas, lipideos, açúcares, minerais e outros. Neste caso, o leite desnatado utilizado neste trabalho, contém principalmente caseína que pode está influenciando na redução deformação de biofilme de L. monocytogenes. Em contraste, E. coli e $S$. aureus mostrados acima, que resultaram em aumento da fixação em superfície de poliestireno na presença do leite. Apesar de algumas controvérsias, a maioria dos estudos indicam que leite ou seus componentes individuais, tais como caseína, $\beta$ lactoglobulina, $\alpha$-lactolbumina são capazes de adsorver em superfícies abióticas, como aço inóxidável reduzindo a eficiência de fixação de uma variedade de patógenos, incluindo $S$. aures, L. monocytogenes e S.marcescens (BARNES et al., 1999). 
Sabe-se que as proteínas presentes no leite são quase todas ácidas o que pode estar relacionada com a capacidade de reduzir a adesão bacteriana. Enquanto proteínas básicas e não-polares promovem um aumento da adesão (DAT et al., 2010). Além disso, a superfície de células bacterianas são negativamente carregadas, e esta carga varia, dependendo da espécie do microrganismo e do ambiente de crescimento. Portanto, há uma influência de forças repulsivas na interação de curto alcance entre a superfície de células bacterianas e a superfície de poliestireno. Esta repulsão pode causar o efeito de redução da ligação de superfícies que foram condicionados com leite (DAT et al., 2010, 2014).

Hamadi e colaboradores, (2014) mostraram que em comparação com os substratos: leite UHT, semi-desnatado e o desnatado, o último proporcionou maior adesão de células de S. aureus em superfície de aço inoxidável. Um dos principais fatores envolvidos refere-se à influência da adsorçãode proteínas do leite na superfície de estudo, as quais tem a capacidade de alterar a hidrofobicidade da superfície possibilitando a adesão de microrganismos (KSONTINI; KACHOURI; HAMDI, 2013). O que também pode ter influenciado os resultados obtidos neste trabalho para a $S$. aureus e $E$. coli que formaram maior quantidade de biofilme na presença de leite.

\subsubsection{Microscopia de Fluorescência}

A microscopia de fluorescência, permitiu a visualização dos biofilmes com o uso combinado de corantes fluorogênicos para diferenciação de células viáveis e não-viáveis, antes e após o tratamento com o ramnolipídeo. Sendo assim, células do biofilme coradas em vermelho nas imagens abaixo representam as células não-viáveis, já as células em verde representam as células viáveis, e as áreas em preto representam o fundo da superfície de poliestireno onde não houve adesão celular. Neste experimento, a viabilidade celular das células presentes nos biofilmes de todos os microrganismos de estudos foram avaliados nas melhores condições encontradas nas análises de quantificação de células viáveis quando utilizou-se o reagente rezasurina, item 5.4.2.

As Figuras 26, 27 e 28 mostram as imagens de microscopias de fluorescência dos biofilmes formados por cada um dos microrganismos estudados (E. coli, S. aureus e L. monocytogenes, respectivamente) em meios nutricionais: caldo nutriente, extrato de levedura 
com triptona de soja e leite, em superfície de poliestireno, antes e após o tratamento com o ramnolipídeo. De acordo com as microscopias de fluorescência, utilizando kit de viabilidade celular, os microrganismos que apresentaram maior produção de exopolissacarídeos grande parte das células avaliadas encontraram-se viáveis pois apresentaram coloração verde ao serem coradas, isso para os controles, esse mesmo comportamento não foi observado após o tratamento com o ramnolipídeo. Estes resultados ressaltam a importância de exopolissacáridos na manutenção da integridade das células presentes no interior do biofilme e na mediação do potencial patogênico e do estilo de vida do mesmo.

A observação das amostras controles e aquelas tratadas com o ramnolipídeo para os biofilmes de E. coli em diferentes meios de cultivo mostrou que houve diferença entre a quantidade de células viáveis e não-viáveis (Figura 26). Para o meio caldo nutriente observase que as amostras controle (Figuras 26A e B) apresenta células vivas e mortas, muito embora apresente em sua maior parte células não-viáveis (em vermelho). Em relação aos tratamentos (Figuras 26C e D) todas as células do biofilme apresentaram morte celular em resposta ao estresse causado peloo ramnolipídeo, promovendo a morte da maioria das células. Já em leite foi possível observar poucas células viáveis, tanto nos controles (Figuras 26E e F) como nos tratamentos (Figuras $26 \mathrm{G} \mathrm{e} \mathrm{H}$ ).

Figura 26-Microscopia de fluorescência de biofilmes de E.coli ATCC 43895, sobre superfície de poliestireno formados em $\mathrm{CN}$, onde (A e B) representam os controles e $(\mathrm{C}$ e $\mathrm{D})$ os tratamentos com $1 \%$ de $\mathrm{RL}$ à $25{ }^{\circ} \mathrm{C}$; e em leite, onde (E e F) são os controles e $(\mathrm{G} \mathrm{e} \mathrm{H})$ os tratamentos com $0,05 \%$ de RL à $37^{\circ} \mathrm{C}$, (avaliados em $24 \mathrm{~h}$ ).
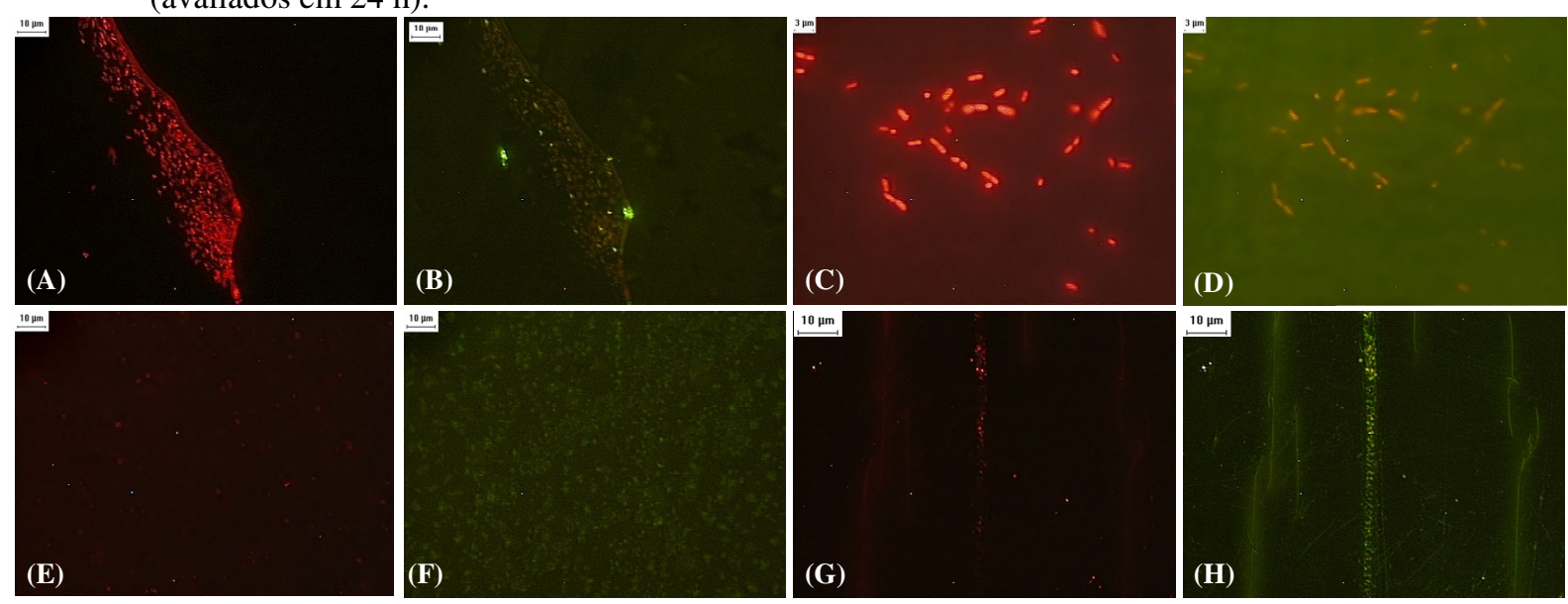

Para os biofilmes de $S$. aureus formados na presença de caldo nutriente tanto nas amostras controle (Figuras 27A e B) como nos tratamentos (Figura 27C e D), observa-se a 
presença de células viáveis e não-viáveis, embora as células não-viáveis estajam presentes em maior quantidade. Para os biofilmes formados em leite houve um comportamento um pouco diferenciado pois os controles (Figuras 27E e F) apresentaram uma grande quantidade de células viáveis e após o tratamento com o ramnolipídeo (Figuras 27G e H) não observou a presença de viabilidade celular.

Figura 27- Microscopia de fluorescência de biofilmes de $S$. aureus ATCC 8095, sobre superfície de poliestireno formados em $\mathrm{CN}$, onde (A e B) representam os controles e (C e D) os tratamentos com 0,05\% de RL à $4{ }^{\circ} \mathrm{C}$, e em leite, onde (E e F) são os controles e $(\mathrm{G} \mathrm{e} \mathrm{H})$ os tratamentos com $1 \%$ de RL à $4{ }^{\circ} \mathrm{C}$, (avaliados em $48 \mathrm{~h}$ ).
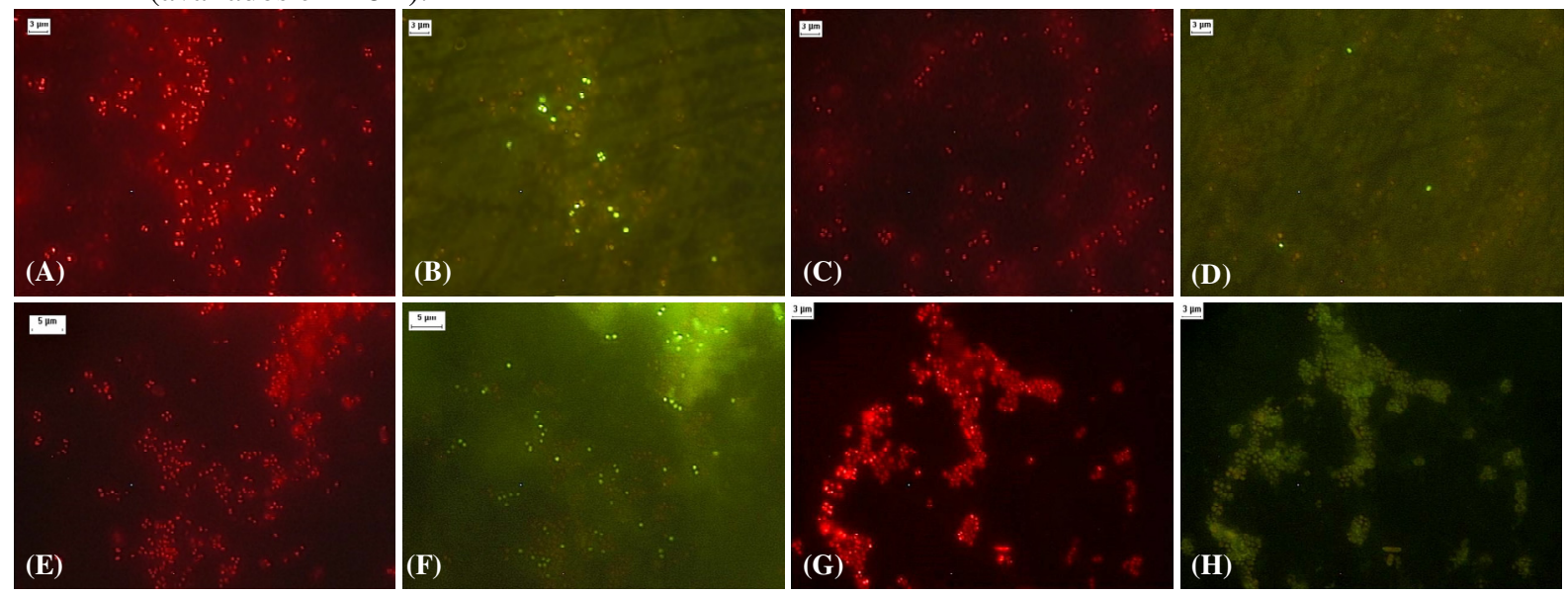

Para os biofilmes de L. monocytogenes formados na presença de meio TSYE tanto nas amostras controle (Figuras 28A e B), como nos tratamentos com o ramnolipídeo (Figura 28C e D) observa-se a coexistência de células viáveis e não-viáveis. Em leite tanto nos controles (Figuras 28E e F) como nos tratamentos com o ramnolipídeo (Figuras 28G e H) também foi observado o mesmo comportamento. Essas análises corroboram com os dados de viabilidade celular quantificados pelo método da resazurina, no mesmo foi encontrado que após o tratamento grande parte das células permaneciam viáveis, como pode-se observar pelas imagens abaixo, onde a maioria encontra-se com a coloração verde. 
Figura 28 - Microscopia de fluorescência de biofilmes de L. monocytogenes ATCC 19112, sobre superfície de poliestireno formados em meio TSYE, onde (A e B) representam os controles e (C e D) os tratamentos com $0,05 \%$ de RL à $4{ }^{\circ} \mathrm{C}$, e em leite, onde (E e F) são os controles e $(\mathrm{G}$ e H) os tratamentos com $1 \%$ de RL à $4{ }^{\circ} \mathrm{C}$, (avaliados em $48 \mathrm{~h}$ ).
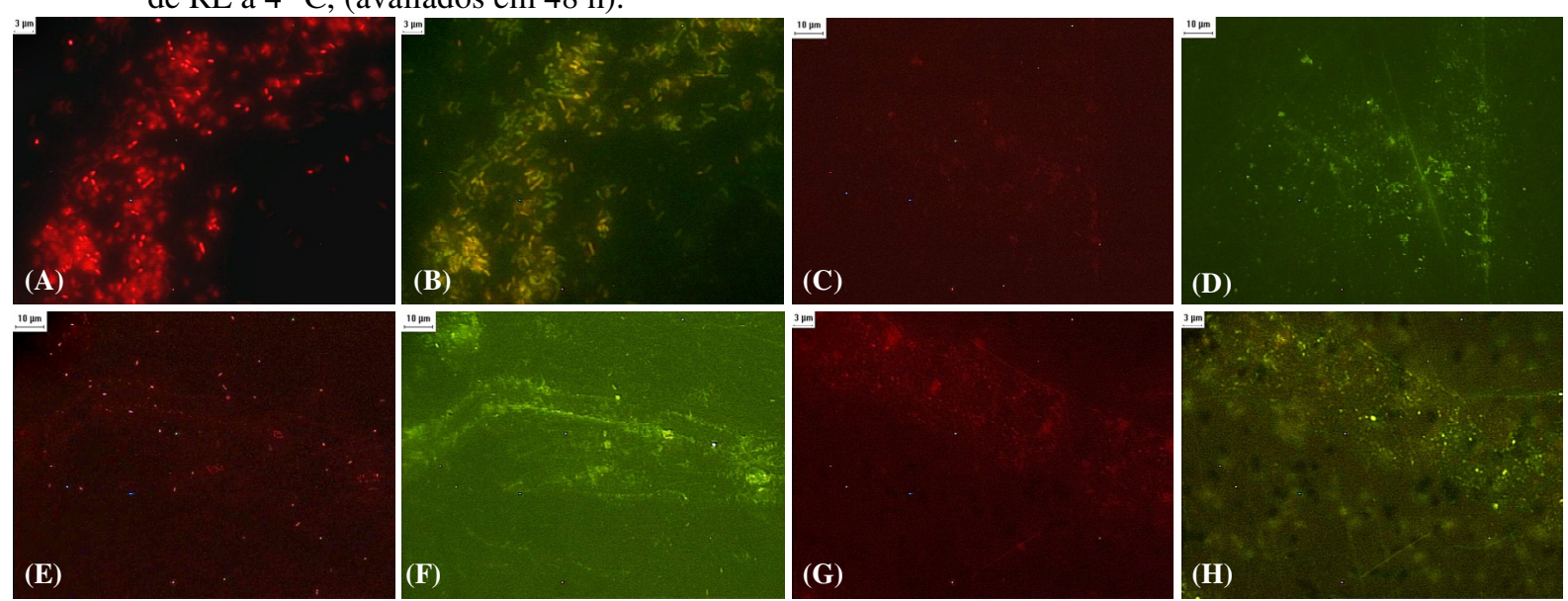

\subsection{Caracterização físico-química do ramnolipídeo}

\subsubsection{Determinação da concentração micelar crítica do ramnolipídeo}

A concentração micelar crítica $(\mathrm{CMC})$ é a característica físico-química mais importante de um surfatante.O valor da CMC demonstra diretamente a eficiência de um surfatante, ou seja, essa propriedade é um fator essencialna escolha destas moléculas para aplicações específicas. Propriedades como a tensão superficial e interfacial de um sistema que contém um surfatante puro não varia quando a concentração está acima de seu valor de CMC, uma vez que a maioria das moléculas encontram-se formando micelas (DALTIN, 2011).

A CMC de ramnolipídeo depende da fonte da produção e do tipo de bactéria usada para produzi-lo. Por exemplo, ramnolipídeos produzidos por diferentes cepas de $P$. aeruginosa exibem diferentes valores de CMC, confirmando a dependência da linhagem bacteriana. De acordo com Mulligan (2005), algumas cepas de P. aeruginosa foram capazes de produzir ramnolipídeos com CMC variando desde 10 a $230 \mathrm{mg} \mathrm{L}^{-1}$ e foram capazes de diminuir as tensões superficiais de água de 72,9 a $29 \mathrm{mN} \mathrm{m}^{-1}$. Outro fator que afeta a sua CMC é proporção entre di-ramnolipídeo e mono-ramnolipídeoem solução. Estudos de Tummino, (1993) e colaboradores indicaram que ramnolipídeo pode formar micelas relativamente pequenas quando comparado com surfatantes de origem sintética, tais como SDS (59 nm \pm 5$)$, Triton X-100 $(121 \mathrm{~nm} \pm 1)$, e Tween $(133 \mathrm{~nm} \pm 1)$. Assim é importante 
conhecer a CMC do ramnolipídeo utilizado neste trabalho, pois a mesma pode ser influenciada por inúmeros fatores. A Figura 29 mostra o gráfico gerado pelo software Attension, que estimou o valor da CMC para 0,004\%. Assim, todos os experimentos do presente estudo foram realizados acima da CMC.

Figura 29- Determinação da CMC para o ramnolipídeo (RL) em solução aquosa pH 7,0 $\pm 0,2$ à $25^{\circ} \mathrm{C}$.

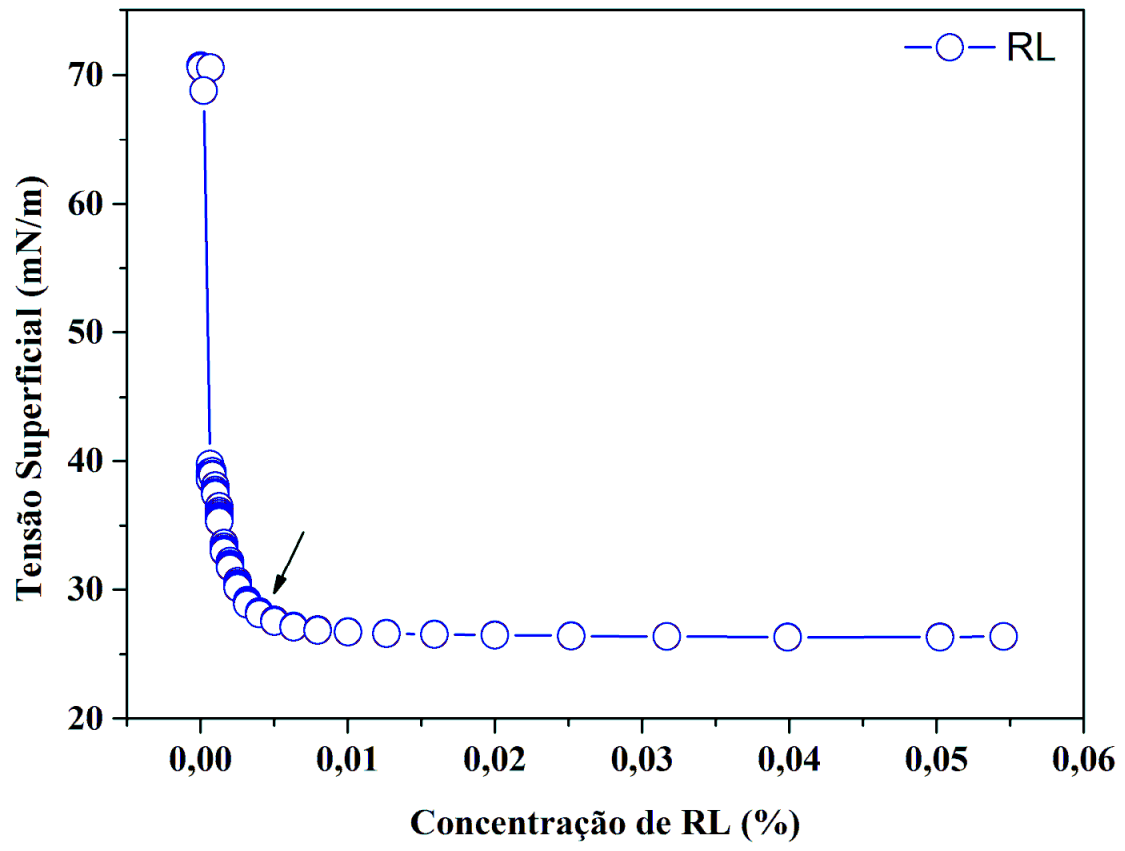

5.8.2 Análise físico-química do comportamento das micelas de ramnolipídeo: efeitos da concentração e temperatura.

\subsubsection{Espalhamento dinâmico de luz}

Para analisar a variação dos diâmetros hidrodinâmicos e consequentemente inferir nos tamanhos das micelas ou agregados micelares de ramnolipídeo, uma série de medidas de espalhamento dinâmico de luz (DLS) foram realizadas em diferentes concentrações $(0,05,0,1$, 0,25, 0,5,1 e $2 \%$ ) e temperaturas de incubação $\left(10,25\right.$ e $\left.37^{\circ} \mathrm{C}\right)$. Embora exista uma incerteza no tamanho do agregado absoluto medido, tendências na mudança de tamanho para diferentes concentrações do ramnolipídeo e temperaturas podem ser observadas. 
Na Figura 30 são mostrados as intensidades e números de partículas em relação ao diâmetro hidrodinâmico (nm). Quanto às análises de intensidade de espalhamento (Figuras 30 A, C e E) nota-se que em todas as temperaturas analisadas há a presença de dois picos ou mais (no caso de 0,05\%), principalmente quando há um aumento da temperatura. Onde há agrupamentos de partículas bem definidos, um na faixa de diâmetro hidrodinâmico de 1-10 $\mathrm{nm}$, outro entre 10-100 nm e 100-1.000 nm indicando a coexistência de agregados micelares ou pré-micelares com diferentes intensidades. Estes resultados mostram que o sistema é polidisperso, ou seja, apresenta micelas com diferentes tamanhos e intensidades, como pode ser observado pelos diferentes diâmetros hidrodinâmicos (nm) das partículas presentes no meio. Isso pode indicara influência da temperatura de incubação e concentração na diferença morfológicada mistura de ramnolipídeo. Estudos realizados por Sanchez e colaboradores (2007) mostraram que há influência da concentração na formação de agregados micelares do di-ramnolipídeo, quando analisados acima da CMC (71,5 $\left.\mathrm{mg} \mathrm{L}^{-}\right)$em $\mathrm{pH} \mathrm{7,4.} \mathrm{Este} \mathrm{trabalho}$ encontrou três intervalos de tamanhos de agregados (diâmetro hidrodinâmico): o primeiro entre 43-66 nm, o segundo entre 350-550 nm ( $1 \mathrm{mM}$ de RL) e o terceiro acima de $1.500 \mathrm{~nm}$ (2-5 mM de RL), evidenciando a coexistência de micelas e agregados maiores. Estes dados corroboram com os resultados encontrados neste trabalho uma vez que utilizou-se a mistura de homólogos de ramnolipídeo (mono e di).

No entanto, apesar de haver partículas com tamanhos diferentes, existe uma predominância de moléculas com diâmetros hidrodinâmicos entre 1 e 10 nm, como pode-se observar nas curvas de distribuição por números de partículas (Figuras 30B, D e F). Em concentrações mais baixas de ramnolipídeo como $0,05 \%, 0,1 \%$ e 0,25 \% observa-se a presença de duas populações bem definidas à medida que há uma diminuição da temperatura $\left(10^{\circ} \mathrm{C}\right)$. Acredita-se que esse comportamento pode está relacionado com a proximidade de

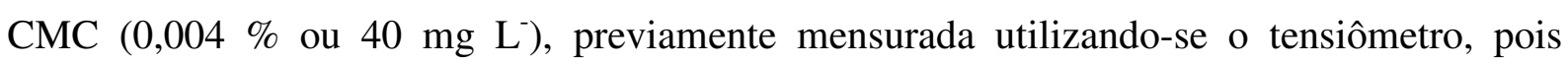
podem coexistem micelas de tamanhos variados, até mesmo menores que $1 \mathrm{~nm}$, indicando a presença de monômeros. Já quando há um aumento de temperatura esse comportamento é menos pronunciado, havendo uma predominância de micelas de mesmo tamanho, indicando que a temperatura pode influenciar no comportamento das micelas de ramnolipídeo, dependendo da concentração analisada. 
Figura 30- Distribuição por tamanho de partículas $(\mathrm{nm})$ do ramnolipídeo por intensidade e número. As análises foram realizadas à $10^{\circ} \mathrm{C}(\mathrm{A}$ e B $), 25^{\circ} \mathrm{C}\left(\mathrm{C}\right.$ e D) e também à $37^{\circ} \mathrm{C}(\mathrm{E}$ e F $)$, variando as concentrações.
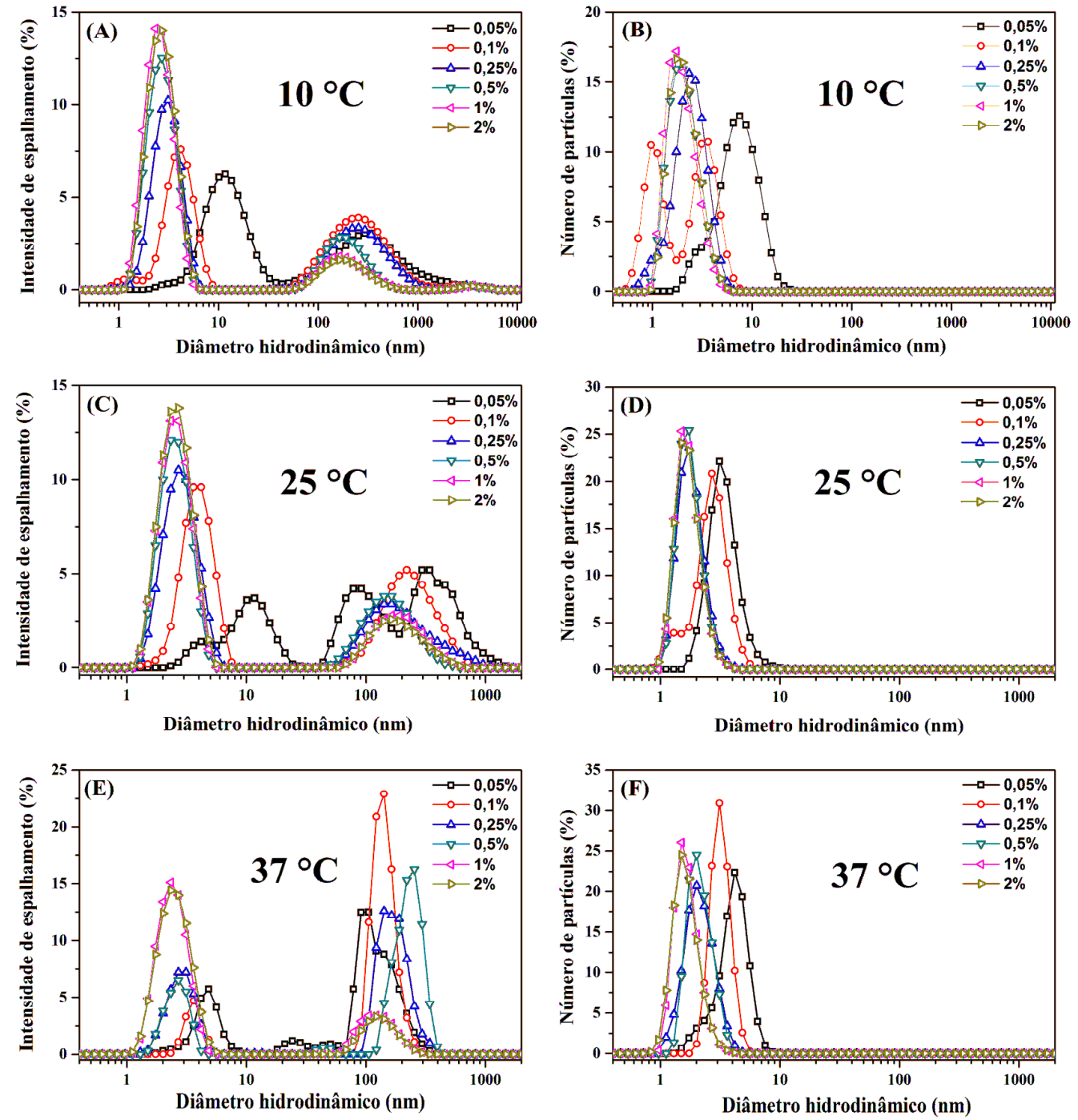

Assim como os surfatantes sintéticos, os biosurfatantes são capazes de formar uma variedade de microestruturas, tais como micela esférica, elipsóides, globular, e cilíndricas; vesículas esféricas e irregulares ou tubular irregulares; folhas lamelares, dentre outros (RAZA et al, 2010). A morfologia de agregados pode ser afetada por diversos fatores como: concentração, pH, temperatura, contra-íons, força iônica, presença de álcoois e metais. Em trabalhos realizados por RAZA e colaboradores (2010), foi demonstrado que as estruturas globais de um mono-ramnolipídeo pode ser afetada pelo $\mathrm{pH}$, o cádmio, o octadecano, enquanto que as de um di-ramnolipídeo são afetadas pela concentração. Guo et al., (2009) também observou o efeito da concentração no comportamento de micelização de extratos brutos contendo ramnolipídeos, e constatou que o aumento da concentração está intimamente relacionado com a formação de agregados de micelas. 
Uma das funções mais importantes destes agregados micelares é a capacidade de solubilização (RAZA et al., 2010). No entanto, a capacidade de solubilização de agregados de ramnolipídeo tem sido raramente estudado. O avanço do conhecimento sobre o comportamento de agregação de ramnolipídeo poderá ajudar a introduzir estas moléculas tensoativos em aplicações de alto valor agregado (RAZA et al., 2010).

\subsubsection{Espalhamento de raios-X a baixo ângulo}

A Figura 31 mostra curvas de espalhamento de SAXS obtidos das micelas de ramnolipídeo nas concentrações de $0,25,0,5,1,0$ e 2,0 \%, pH 7,0, nas temperaturas de $15^{\circ} \mathrm{C}$ (Figura 31A) e $37^{\circ} \mathrm{C}$ (Figura 33B). As faixas mais baixas de concentração de ramnolipídeo $(0,05$ e $0,1 \%)$, não foram possíveis de serem observadas devido a baixa intensidade de espalhamento, sendo insuficiente para realização dos ajustes adequadamente. As linhas em preto correspondem aos melhores ajustes das curvas experimentais, assumindo que a forma das micelas de ramnolipídeo seja um elipsóide prolato.

As curvas de SAXS para as micelas de ramnolipídeos nas temperaturas de $15{ }^{\circ} \mathrm{C}$ e 37 ${ }^{\circ} \mathrm{C}$ são muito similares, como pode-se observar nas Figuras 31A e B. As curvas de SAXS para as diferentes concentrações de ramnolipídeo analisadas apresentaram dois picos bem definidos, um com intensidade máxima em $\mathrm{q} \cong 0,04 \AA^{-1}$ e outro em $\mathrm{q} \cong 0,22 \AA^{-1}$. O primeiro pico indica uma interação repulsiva entre as micelas de ramnolipídeo. A função S(q) (Equação 3), fator de estrutura intermicelar, contribui de forma significativa para a formação deste pico, pois está associado à interação eletrostática repulsiva entre micelas carregadas. Já o segundo é característico do fator de forma intramicelar P (q) (Equação 3). Além disso, podese observar que os picos característicos da micela se tornam mais intensos à medida que a concentração de ramnolipídeo aumenta em ambas as temperaturas. Esta mudança está relacionada com o aumento do número de micelas no meio, mostrando que é independente da temperatura de incubação. 
Figura 31- Curvas de SAXS para o ramnolipídeo nas concentrações de 0,25, 0,5, 1 e $2 \%$, pH 7,0 $\pm 0,2$. As análises foram realizadas nas temperaturas de $15^{\circ} \mathrm{C}(\mathrm{A})$ e $37^{\circ} \mathrm{C}(\mathrm{B})$.
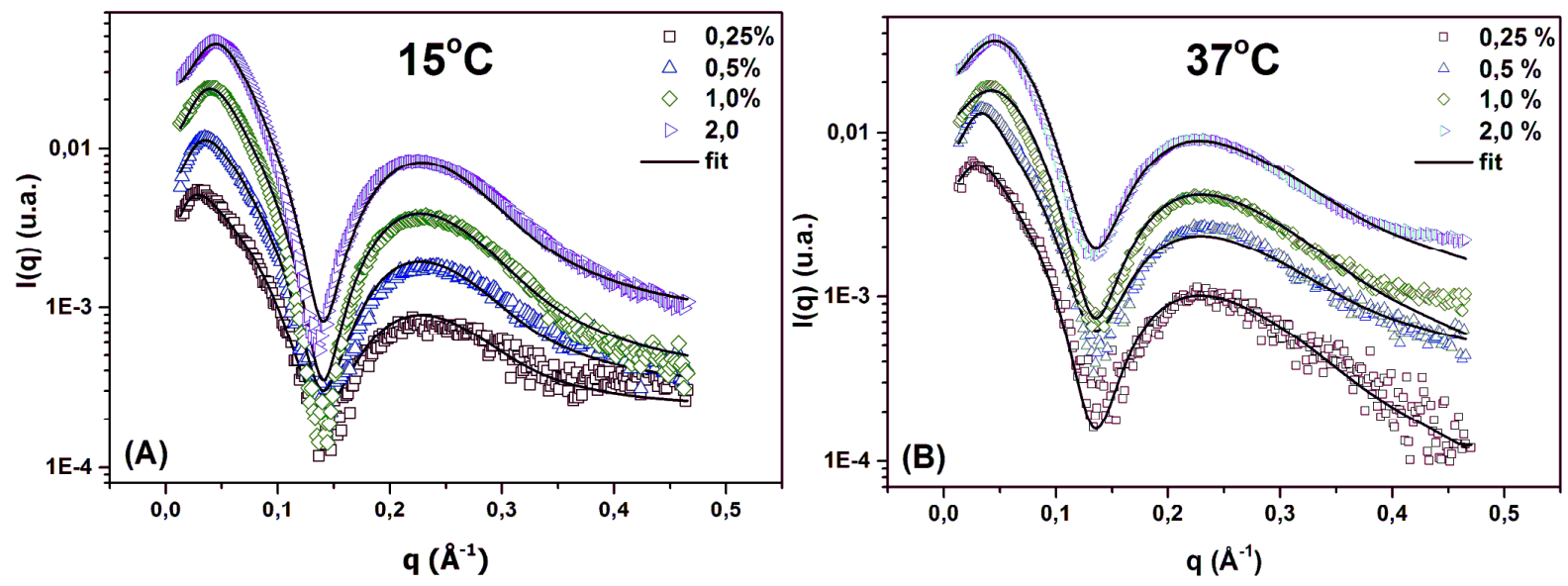

Em estudos realizados com micelas de surfactantes de origem não biológica como: SDS (aniônico) (CAETANO et al, 2002) e HPS (zwiteriônico) (GANDINI et al, 2005) também apresentaram um segundo pico bem definido com intensidade máxima em $q=0,17 \AA^{-}$ ${ }^{1}$ e $\mathrm{q}=0,12 \AA^{-1}$, respectivamente, o qual é característico do fator de forma intramicelar P (q) (Equação 3). No caso das micelas de ramnolipídeo, também foi observado um segundo pico nas curvas de SAXS em ambas as concentrações e temperaturas analisadas próximo às esses valores.

Neste sentido, pode-se observar que os resultados de SAXS (Figuras 31A e B) são consistentes com aqueles obtidos por DLS, principalmente, com relação as curvas de distribuição por número de partículas (Figuras 30B, D e F). É importante mencionar que as mudanças sutis observadas nas curvas de distribuição por número de partículas não são detectáveis por SAXS devido essas partículas possuírem tamanhos bem similares. Contanto DLS e SAXS sugerem que embora existam micelas de diferentes tamanhos as estruturas das mesmas não apresentam diferença significativa em relação às concentrações de ramnolipídeo e das temperaturas analisadas. 


\subsection{Principais resultados para cada bactéria de estudo}

\subsubsection{Biofilmes de Escherichia coli}

A formação de biofilme de E. coli foi influenciada pelo meio de cultivo, pois sua adesão ao poliestireno em relação ao tempo apresentou-se maior quando na presença do meio de cultivo leite $(\mathrm{pH} \mathrm{6,5)}$ do que em caldo nutriente $(\mathrm{pH} 7,4)$. Estes resultados corroboram com a literatura uma vez E. coli O157:H7 apresenta alta resistência em ambientes ácidos como alimentos derivados do leite, dentre eles iorgutes e queijos (BUCHANAN; EDELSON, 1999). Após o estabelecimento dos biofilmes, os mesmos foram submetidos ao tratamento com o ramnolipídeo, onde a melhor condição de remoção do biofilme de E. coli para o meio caldo nutriente foi na temperatura de $25{ }^{\circ} \mathrm{C}$, na concentração de $2 \%$ de RL, na qual houve $33,3 \%$ de remoção. Já em meio leite foi na temperatura de $37{ }^{\circ} \mathrm{C}$, também na concentração de $2 \%$ de RL, com remoção de $80 \%$ do biofilme (Figura 32). Nessas condições foi observado através da técnica de DLS uma polidispersividade presente na amostra indicando a presença de duas estruturas de moléculas bem definida, uma entre 1-10 nm e outra entre 100-1000 nm. No entanto, em relação ao número de partículas, os resultados mostraram a predominância de moléculas com diâmetro hidrodinâmico entre 1-10 nm, com cerca de $25 \%$ em ambas as temperaturas. Isso indica que o ramnolipídeo pode está coexistindo na forma de micela, ou agregados micelares maiores em menor número. Os dados de SAXS também mostraram que não houve influência significativa, nas diferentes concentrações e temperaturas analisadas, o que sugere a predominância de apenas uma forma estrutural presente em solução.

Quanto a quantificação de células viáveis frente a ação do ramnolipídeo, as condições que apresentaram maior redução de viabilidade celular do biofilme de E. coli em caldo nutriente foi na temperatura de $25{ }^{\circ} \mathrm{C}$, na concentração de $1 \%$ de RL, na qual houve $16,6 \%$ de redução. Já em meio leite foi na temperatura de $37{ }^{\circ} \mathrm{C}$, na concentração de $0,05 \%$ de RL, com redução de 60,8 \% de células viáveis (Figura 32). E. coli pode crescer em temperaturas entre 10 e $46^{\circ} \mathrm{C}$, e suas estirpes mais virulentas se adaptam bem em temperaturas inferiores a $15^{\circ} \mathrm{C}$ (FARROKH et al., 2013). De acordo com Amer et al., (2010), E. coli O157: H7 têm uma alta tolerância ao frio, e pode sobreviver à temperaturas abaixo de zero $\left(-18\right.$ a $\left.-20{ }^{\circ} \mathrm{C}\right)$, como por exemplo dentro de produtos lácteos. E apesar de procedimentos térmicos, como por exemplo, a pasteurização do leite a $72{ }^{\circ} \mathrm{C}$ durante 15 segundos, inativar E. coli O157: H7, 
uma carga microbiana superior ou a proliferação de bactérias pode diminuir a eficiência de pasteurização, levando a níveis inaceitáveis de potenciais agentes patogênicos restantes no leite (SILVA et al., 2010).

Figura 32- Esquema representativo da ação do ramnolipídeo sobre os biofilmes formados por E.coli ATCC 43895, em caldo nutriente e em leite. Onde (A1 e B1) representam as melhores condições de remoção e (A2 e B2) as melhores condições de redução de viabilidade celular. Em verde células viáveis e em vermelho as não-viáveis.

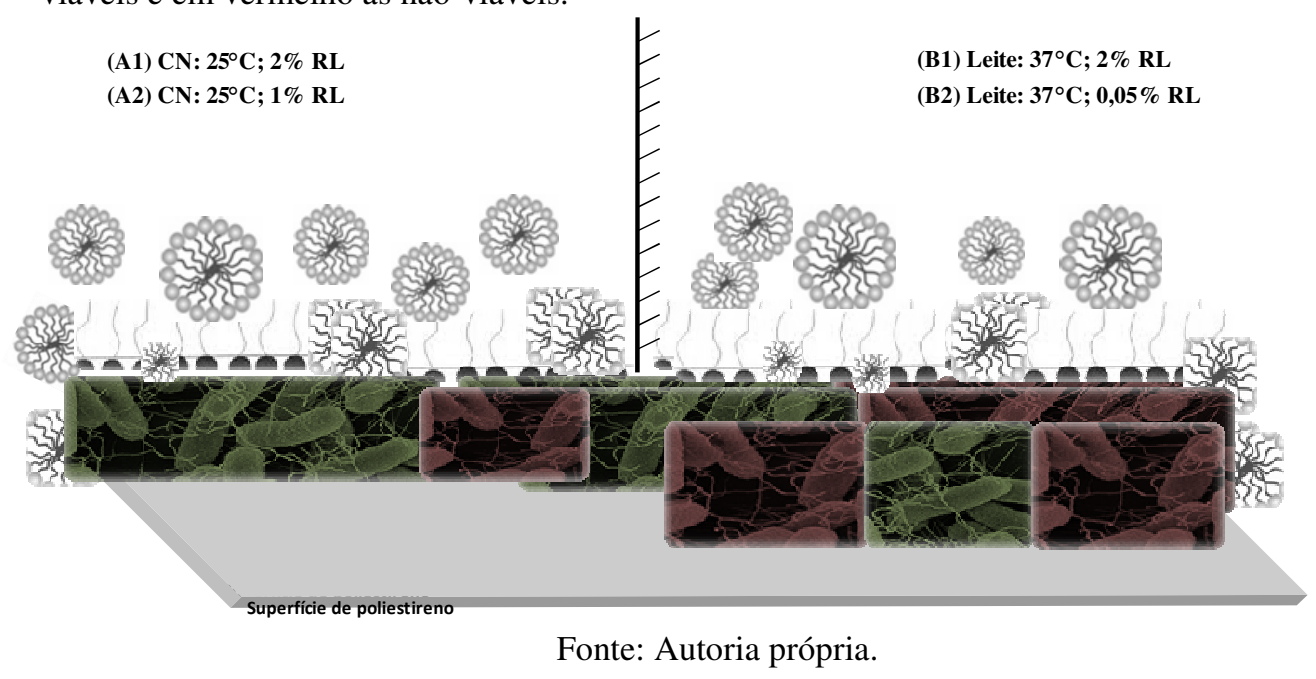

Os dados de ângulo de contato mostraram que aqueles biofilmes que apresentaram maior remoção também resultaram em uma redução de hidrofobicidade, principalmente após o tratamento com o ramnolipídeo. Para os biofilmes formados na presença do caldo nutriente à $25^{\circ} \mathrm{C}$, o ângulo de contato medido foi de $63,51^{\circ}$ e após o tratamento o ângulo foi reduzido para 20,62 ${ }^{\circ}$. Em leite também houve redução de hidrofobicidade de 71,62 ${ }^{\circ}$ (controle) para $21,55^{\circ}$ (tratamento).

A composição bioquímica da matriz polimérica extracelular presente no biofilme de $E$. coli, também foi analisada nas melhores condições de remoção dos biofilmes pelo ramnolipídeo, assim como as análises do ângulo de contato. Os resultados mostraram maior presença de carboidratos e proteínas, principalmente em biofilmes formados em leite. Nessa condição a bactéria apresentou uma maior formação de material polimérico extracelular, como pode-se observar através das imagens de microscopia eletrônica de varredura.

As análises qualitativas de microscopia eletrônica de varredura dos biofilmes mostraram a morfologia dos biofilmes de E. coli nos dois meios analisados, antes e após o tratamento com o ramnolipídeo. Ambos apresentaram perfis diferentes, no leite houve uma 
maior formação de matriz polimérica extracelular, quanto no caldo nutriente não foi observado a mesma situação. Porém as células apresentaram-se reunidas em conglomerados bacterianos, e ao seu redor foi observado uma suposta estrutura polimérica, a qual desapareceu após o tratamento. Quanto as imagens de microscopia de fluorescência notou-se a presença de células viáveis e não-viáveis para os biofilmes de ambos os meios. Sendo que no controle do caldo nutriente havia mais células vivas do que no controle do leite. Acreditase que o corante pode ter interação inespecífica com o material orgânico, impossibilitando o acesso deste às células presentes no biofilme.

\subsubsection{Biofilmes de Staphylococcus aureus}

Os biofilmes de $S$. aureus não foram influenciados pelos meios de cultivo analisados, pois o mesmo apresentou alta capacidade de formar biofilme em superfície de poliestireno tanto em caldo nutriente quanto em leite. Uma vez que o material de superfície é exposto em meio aquoso com nutrientes, as suas propriedades interfaciais muitas vezes são modificadas pelo fluido envolvente através da adsorção de compostos orgânicos, como proteínas, carboidratos, lipídeos e minerais (CHMIELEWSKI; FRANK, 2003). De fato as análises bioquímicas da matriz polimérica extracelular mostraram maiores quantidades de carboidratos e proteínas, principalmente em leite.

Essas alterações foram constatadas através das análises dos ângulos de contato dos biofilmes de $S$. aureus formados na presença do caldo nutriente e em leite. Em ambos os meios nutricionais foi observado a diminuição da hidrobobicidade da superfície, pois os ângulos de contato diminuíram em relação ao controle (apenas poliestireno) e após o tratamento esse efeito foi bem mais pronunciado.

Os dados de remoção dos biofilmes mostraram maior eficiência do ramnolipídeo em temperaturas e concentrações variadas, sendo que os melhores resultados para o caldo nutriente foi à $25{ }^{\circ} \mathrm{C}$, com $0,1 \%$ de $\mathrm{RL}$, com $34,7 \%$ de remoção e em leite foi à $4{ }^{\circ} \mathrm{C}$, com $0,05 \%$ de RL, com 88,9 \% de remoção (Figura 33). Esses resultados foram observados qualitativamente através das análises de microscopia eletrônica de varredura, nas quais mostraram a grande formação de matriz polimérica extracelular tanto em $\mathrm{CN}$ como em leite, 
mostrando a grande capacidade de formação de biofilmes, apesar da diferença da composição dos meios estudados.

Quanto a quantificação de células viáveis, a melhor condição de redução de viabilidade celular foi obtida para o biofilme formado em meio caldo nutriente, na temperatura de $4{ }^{\circ} \mathrm{C}$, e concentração de $0,05 \%$ de RL, na qual houve 58,6 \% de redução de viabilidade celular. Já em meio leite também foi na temperatura de $4{ }^{\circ} \mathrm{C}$, na concentração de $1 \%$ de RL, com redução de 29,7 \% de células viáveis (Figura 33). Nesse sentido nota-se o potencial de ação dessas moléculas em baixas temperaturas e em faixas menores de concentração. Esses resultados foram observados qualitativamente através das análises de microscopia de fluorescência, nas quais mostraram a presença de células viáveis e nãoviáveis, em CN e em leite. Porém, notou-se que em ambos os meios a coexistência de células vivas e mortas e vivas, principalmente no controle. Após tratamento com o ramnolipídeo, a maioria das células encontraram-se não-viáveis nos dois meios.

Figura 33- Esquema representativo da ação do ramnolipídeo sobre os biofilmes formados por S. aureus ATCC 8095, em caldo nutriente e em leite. Onde (A1 e B1) representam as melhores condições de remoção e (A2 e B2) as melhores condições de redução de viabilidade celular. Em verde células viáveis e em vermelho as não-viáveis.

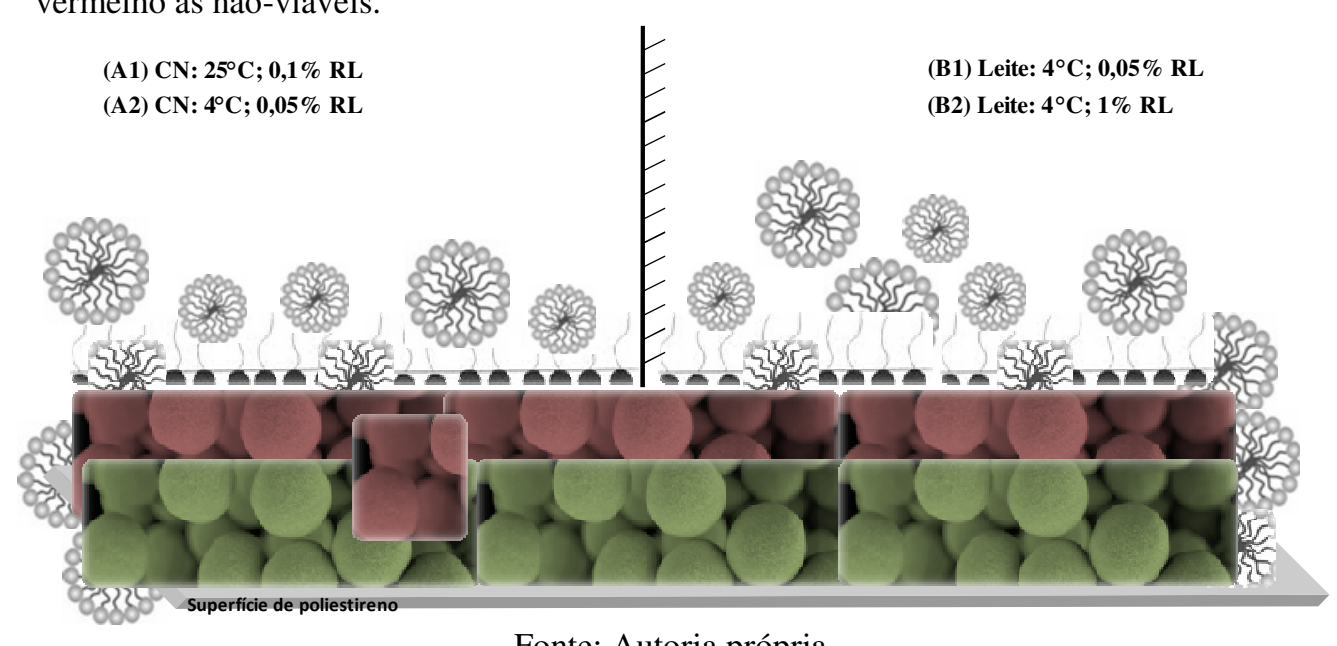

Fonte: Autoria própria.

\subsubsection{Biofilmes de Listeria monocytogenes}

L. monocytogenes apresentou capacidade de formação de biofilme em superfície de poliestireno, porém houve influência da composição dos meios de cultivo utilizados, pois a mesma apresentou alta capacidade de formar biofilme em caldo TSYE ( $\mathrm{pH} 7,3)$ ao contrário 
do meio contendo leite desnatado ( $\mathrm{pH}$ 6,5), como pode-se observar na Figura 34. Alguns fatores que podem interferir na formação de biofilmes às superfícies são a presença do apêndice celular (PARIZZI et al, 2004;. CHAE et al., 2006), hidrofobicidade e carga de microrganismos e as superfícies envolvidas (MEYLHEUC et al., 2006), bem como a capacidade para produzir ou não MPE. Neste caso, os resultados para L. monocytogenes mostraram baixa capacidade de formação de biofilme principalmente na presença de leite. Barnes et al., (1999) também mostraram a influência do tipo de leite na formação de alguns microrganismos, seus resultados mostraram que houve redução da adesão de Listeria monocytogenes e Serratia marcescens ao aço inoxidável quando na presença de leite desnatado. As observações conflitantes sobre a formação dos biofilmes pode ser reflexo das diferentes superfícies e cepas analisadas, como também as condições experimentais aplicadas nos estudos. Isso também pode ser uma indicação da diversidade de respostas exibido por diferentes grupos bacterianos.

Após a formação dos biofilmes, os mesmos foram submetidos à ação do ramnolipídeo e as melhores condições de tratamento em meio de cultivo ocorreu a $37{ }^{\circ} \mathrm{C}$, na concentração de $0,5 \%$ de RL, na qual houve $35,3 \%$ de remoção. Nessas condições de tratamento as análises de DLS mostraram a coexistência de moléculas de ramnolipídeo de tamanhos entre 1$10 \mathrm{~nm}$ e 100-1000 nm, sendo que a primeira em maior quantidade. Já em leite foi na temperatura de $4{ }^{\circ} \mathrm{C}$, na concentração de $0,5 \%$ de RL, com remoção de 63,6 \% do biofilme (Figura 34). Esses resultados foram observados qualitativamente através das análises de microscopia eletrônica de varredura, nas quais mostraram a grande formação de matriz polimérica extracelular em TSYE, enquanto que em leite essa característica não foi observada.

Quanto a melhor condição de redução de células viáveis do biofilme de $L$. monocytogenes para o meio TSYE foi na temperatura de $4{ }^{\circ} \mathrm{C}$, na concentração de $0,05 \%$ de RL, na qual houve 17,7 \% de redução de viabilidade celular. Já em meio leite também foi na temperatura de $4{ }^{\circ} \mathrm{C}$, mas na concentração de $1 \%$ de RL, com redução de 63,6 \% de células viáveis (Figura 34). Esses resultados foram observados qualitativamente através das análises de microscopia de fluorescência, nas quais mostraram a presença de células viáveis e nãoviáveis, em TSYE e em leite. Notou-se que em meio TSYE coexistem células vivas e mortas e vivas, tanto no controle como no tratamento, em grande quantidade. Já em leite tanto no 
controle como no tratamento os biofilmes apresentaram mais células viáveis do que nãoviáveis.

Figura 34- Esquema representativo da ação do ramnolipídeo sobre os biofilmes formados por L. monocytogenes ATCC 19112, em TSYE e em leite. Onde (A1 e B1) representam as melhores condições de remoção e (A2 e B2) as melhores condições de redução de viabilidade celular. Em verde células viáveis e em vermelho as não-viáveis.

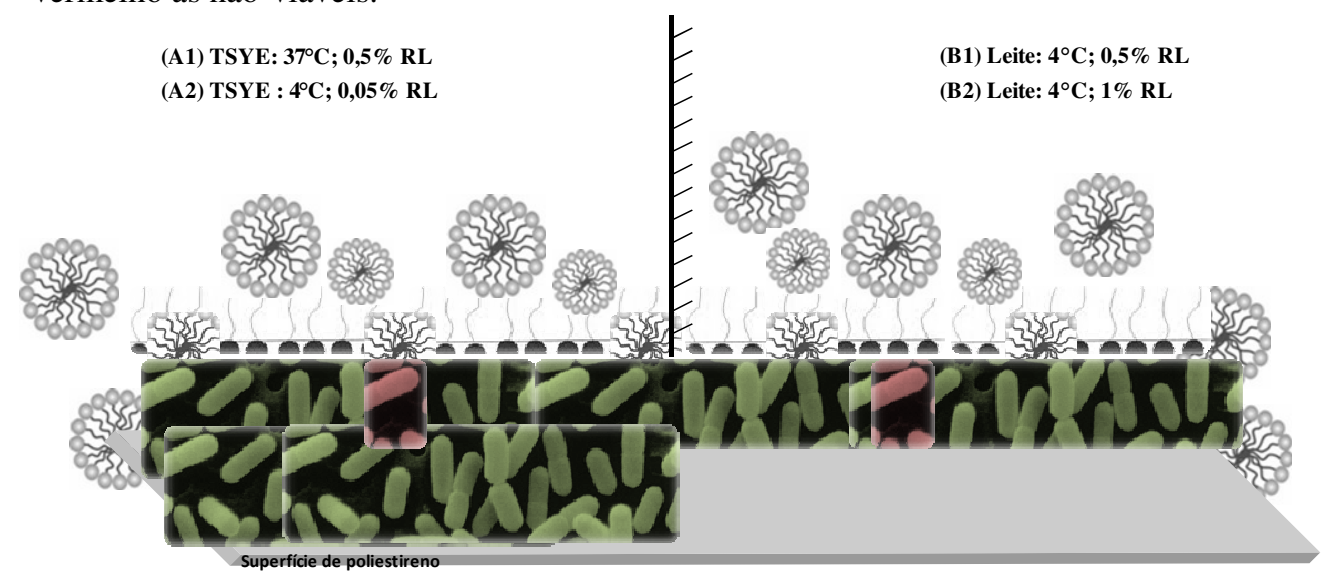

Fonte: Autoria própria.

Os dados do ângulo de contato mostraram que os biofilmes que apresentaram maior remoção também resultaram em uma redução expressiva de hidrofobicidade, principalmente após o tratamento com o ramnolipídeo. Para os biofilmes formados na presença do meio TSYE à $37^{\circ} \mathrm{C}$, o ângulo de contato medido foi de 7,67 ${ }^{\circ}$ e após o tratamento o ângulo foi reduzido para $3,79^{\circ}$. Em leite também houve redução de hidrofobicidade de 43,23 ${ }^{\circ}$ (controle) para 5,82 ${ }^{\circ}$ (tratamento). Como mencionado anteriormente, esse microrganismo formou mais biofilme em TSYE do que em leite, essa característica sugere uma relação entre formação de biofilme e redução de hidrofobicidade. CHAE et al., 2006, também mostraram que estirpes com maior capacidade de produção de MPE são menos hidrofóbicas e têm uma maior capacidade de formar biofilmes. E além disso,verificou-se que quanto maior os níveis de carboidratos extracelulares produzidos por L. monocytogenes, maior foi a sua capacidade para formar biofilmes (BORUCKI et al., 2003). Esses resultados corroboram com os encontrados neste trabalho, pois as análises bioquímicas mostraram que dentre as biomoléculas quantificadas nos biofilmes de L. monocytogenes, os carboidratos apresentaramse em maior quantidade.

Briandet e colaboradores (1999) também observaram o mesmo comportamento para Listeria monocytogenes Scott A, ao investigar a influência das condições de crescimento 
(meio e temperatura) e as propriedades de superfície. Quando as bactérias foram cultivadas a $37{ }^{\circ} \mathrm{C}$ em meio de BHI ou TSYE as superfícies celulares apresentaram-se hidrofílicas. No entanto, esta característica foi reduzida quando as células foram cultivadas em TSYE suplementado com glicose ou ácido láctico. Também podemos correlacionar os resultados obtidos neste trabalho com a diferença de $\mathrm{pH}$ entre os meios TSYE e o leite, no primeiro o $\mathrm{pH}$ foi de $\cong 7,4$ já no segundo 6,5. Resultados obtidos por (MAFU et al., 1990) mostraram que a hidrofobicidade de L. monocytogenes Scott $\mathrm{A}$ aumentava à medida que o $\mathrm{pH}$ diminuía.

L. monocytogenes é extremamente versátil quanto ao seu crescimento celular, o intervalo de temperatura pode variar entre $-1,5$ à $50{ }^{\circ} \mathrm{C}$ e o $\mathrm{pH} 4,3-9,6$. Além disso, é extremamente resistente à stress e tem sido relatado sobreviver durante 132 dias a $4{ }^{\circ} \mathrm{C}$ em meio de crescimento contendo 25,5\% de NaCl (DONNELLY; DIEZ-GONZALEZ, 2013). Portanto, os produtos derivados do leite são alvos de contaminação por L. monocytogenes, pois esse microrganismo apresentar capacidade de crescer em ambientes ácidos e sob condições de armazenamento refrigerado.

A formação de biofilmes de L. monocytogenes pode ocorrer sobre uma vasta gama de superfícies da indústria alimentar, incluindo a borracha utilizada em juntas, aço inoxidável, politetrafluoretileno e poliestireno, sob diferentes condições de nutrientes. Sua capacidade de formar biofilmes e colonizar nichos dentro de locais de processamento pode explicar sua persistência dentro ambientes de processamento. A capacidade de L. monocytogenes para formar um biofilme é dependente do sorotipo, temperatura, nível de nutrientes, exposição prévia a estressores subletais (Ácido) e da topografia e composição da superfície (BONSAGLIA et al., 2014; BARBOSA et al., 2013; MOSQUERA-FERNANDEZ et al., 2014). A extraordinária resistência de L. monocytogenes à ambientes ácidos, temperaturas variadas, umidade e concentração de sal, combinada com a sua capacidade para formar biofilmes e a sua resistência às práticas de limpeza e desinfecção de rotina, o torna um desafio significativo e contínuo para a indústria de alimentos (TODD, 2011). 


\section{CONCLUSÕES}

- As bactérias estudadas formam biofilme em superfície de poliestireno, sendo que biofilmes de L. monocytogenes foi mais expressivo na presença de meio comercial, $E$. coli em leite e $S$. aureus em ambos os meios analisados.

- As imagens de microscopia eletrônica de varredura e de fluorescência mostraram diferenças morfológicas e de viabilidade celular nos biofilmes dos microrganismos estudados dependendo do meio de cultivo.

- O ramnolipídeo apresentou potencial de remoção e redução de viabilidade celular nos biofilmes. E as concentrações, as temperaturas e os meios de cultivo são fatores determinantes.

- Houve redução da hidrofobicidade da superfície principalmente após o tratamento dos biofilmes com o ramnolipídeo.

- Observou-se uma redução nas quantidades das principais biomoléculas presentes nos biofilmes, após o tratamento com o ramnolipídeo (proteínas).

- As análises físico-químicas mostraram que não houve influência significativa das temperaturas e concentrações frente às estruturas micelares do ramnolipídeo. 


\section{SUGESTÕES PARA TRABALHOS FUTUROS}

Considerando os resultados aqui apresentados sugere-se:

-Avaliar outras superfícies utilizadas na indústria de alimentos, como aço inoxidável, vidro, polipropileno, assim como, outros microrganismos de importância alimentar e também culturas mistas.

-Analisar a ação do ramnolipídeo sob diferentes condições de fluxo, maiores intervalos de tempo de formação dos biofilmes de forma a determinar a influência desses parâmetros sob o controle dos biofilmes.

-Avaliar o efeito individual dos componentes majoritários dos ramnolipídeos (mono e di) sobre a remoção e atividade antimicrobiana dos biofilmes de patógenos alimentares.

-Avaliar a toxicidade do ramnolipídeo.

- Analisar a formação/distribuição do biofilme sobre as superfícies por microscopia de força atômica (AFM). 


\section{REFERÊNCIAS}

ABDALLAH, M.; BENOLIEL, C.; DRIDER, D.; DHULSTER, P.; CHIHIB, N.-E. Biofilm formation and persistence on abiotic surfaces in the context of food and medical environments. Archives of Microbiology, v. 196, p. 453-472, 2014.

AKBAS, M. Y.; KOKUMER, T. The prevention and removal of biofilm formation of Staphylococcus aureus strains isolated from raw milk samples by citric acid treatments. International Journal of Food Science and Technology, v. 50, p. 1666-1672, 2015.

AMER, A. A.; AIAD, A. S.; ABD ALLAH, M. A. Effect of yoghurt processing and ice cream manufacture on viability of some foodborne bacteria. Assiut Veterinary Medical Journal, v. n. 56 , p. $108-19,2010$.

ANDRADE, N. J.; PINTO, C. L. O.; ROSADO, M. S. Controle da higienização na indústria de alimentos. In: ANDRADE, N. J. (Ed.) Higiene na indústria de alimentos: avaliação e controle da adesão e formação de biofilmes bacterianos. São Paulo: Varela; 2008. p. 181- 226.

ARENAS, Y.; MANDELA, A.; LILGEB; L. Kynetic resazurin assay (KRA) for bacterial quantification of foodborn pathogens. Proceedings of SPIE, v. 8225, p. 82252K1-82252K5, 2012.

ARAÚJO, L.V.; FREIRE, D. M. G.; NITSCHKE, M. Biossurfactantes: propriedades anticorrosivas, antibiofilmes e antimicrobianas. Química Nova, v. 36, p. 848- 858, 2013.

BANAT, I. M. F., A.; GANDOLFI, I.; BESTETTI, G.; MARTINOTTI, M. G.; FRACCHIA, L.; SMYTH, T. J.; MARCHANT, R. Microbial biosurfactants production, applications and future potencial. Applied Microbiology and Biotechnology, v. 87, n.2, p. 427- 444, 2010.

BANAT, I. M.; RIENZO, M. A. D.; QUINN, G. A. Microbial biofilms: biosurfactants as antibiofilm agents. Applied Microbiology and Biotechnology, v. 98, p. 9915-9929, 2014.

BARBOSA, L. R. S. Estudo de sistemas de relevância biológica por espalhamento de raios-X a baixos ângulos. 2008. 226 f. Tese (Doutorado em Ciências)- Instituto de Física, Universidade de São Paulo, São Paulo, 2008.

BARBOSA, L. R. S.; CAETANO, W; ITRI, R.; HOMEM-de-MELO,P.; SANTIAGO, P. S.; TABAK, M. Interaction of phenothiazine compounds with zwitterionic lysophosphatidylcholine micelles: small angle X-ray scattering eletronic absorption spectroscopy, and theoretical calculations. Journal Physical Chemistry B, v. 110, n. 26, p. 13086-13093, 2006.

BARBOSA, J.; MAGALHÃES, R.; SANTOS, I.; FERREIRA, V.; BRANDAO, T. R. S.; SILVA, J.; ALMEIDA, G.; TEIXEIRA, P. Evaluation of antibiotic resistance patterns of food and clinical Listeria monocytogenes isolates in Portugal. Foodborne Pathogens and Disease, v. 10, p. 861- 866, 2013. 
BARNES, L.-M.; LO, M. F.; ADAMS, M. R.;CHAMBERLAIN, A. H. L. Effect of milk proteins on adhesion of bacteria to stainless steel surfaces. Applied and Environmental Microbiology, v. 65, n. 10, p. 4543- 4548, 1999.

BLACKLEDGE, M. S; WORTHINGTON, R. J; MELANDER, C. Biologically inspired strategies for combating bacterial biofilms. Current Opinion in Pharmacology, v. 13, p. 699 - 706, 2013.

BONSAGLIA, E. C. R.; SILVA, N. C. C.; A. JÚNIOR, F.; ARAÚJO JÚNIOR, J. P.; TSUNEMI, M. H.; RALL, V. L. M. Production of biofilm by Listeria monocytogenes in different materials and temperatures. Food Control, v. 35, p. 386- 391, 2014.

BOWER, C. K.; DAESCHEL, M. A. Resistance responses of microorganisms in food environments.International Journal of Food Microbiology, v. 50, p. 33- 44, 1999.

BRADEN, C. R.; TAUXE, R. V. Emerging trends in foodborne diseases. Infectious Disease Clinics of North America, v. 27, n. 3, p. 517- 533, 2013.

BRIANDET, R.; MEYLHEUC, T.; MAHER, C.; BELLON-FONTAINE, M. N. Listeria monocytogenes Scott A: Cell surface charge, hydrophobicity, and electron donor and acceptor characteristics under different environmental growth conditions. Applied and

Environmental Microbiology, v. 65, n. 12, p. 5328- 5333, 1999.

BUCHANAN, R. L.; EDELSON, S. G. Effect of pH dependent, stationary phase acid resistance on the thermal tolerance of Escherichia coli O157:H7. Food Microbiology, v. 16, 447- 58, 1999.

BURGESS, C.; DESVAUX, M.; OLMEZ, H. 1st Conference of BacFoodNet: mitigating bacterial colonisation in the food chain: bacterial adhesion, biocide resistance and microbial safety of fresh produce. Research in Microbiology, v. 165, p. 305- 310, 2014.

CAETANO, W.; GELAMO, E. L.; ITRI, R.; TABAK, M. Chlorpromazine and sodium dodecyl sulfate mixed micelles investigated by small angle X-ray scattering. Journal of Colloid and Interface Science, v. 248, p. 149-157, 2002.

CAIXETA, D. S. Sanificantes químicos no controle de biofilmes formados por duas espécies de Pseudomonas em superfície de aço inoxidável. 2008. 75 f. Dissertação (Mestrado em Microbiologia) - Universidade Federal de Lavras, Lavras, 2008.

CAPPITELLI, F.; POLO, A.; VILLA, F. Biofilm formation in food processing environments is still poorly understood and controlled. Food Engineering Reviews, v.6, p. 29- 42, 2014.

CAPITA, R.; RIESCO-PELÁEZ, F.; ALONSO-HERNANDO, A.; ALONSO-CALLEJA, C. Exposure of Escherichia coli ATCC 12806 to Sublethal concentrations of food-Grade biocides influences its ability to form biofilm, resistance to antimicrobials, and ultrastructure. Applied and Environmental Microbiology, v. 80, n. 4, p. 1268-1280, 2014.

CENTERS FOR DISEASE CONTROL AND PREVENTION (CDC). Estimating foodborne illness, 2011. Disponível em: http://www.cdc.gov/foodborneburden/estimates-overview.html. Acesso em: 12 mar. 2015. 
CICCIO, P. D.; VERGARA, A.; FESTINO, A. R.; PALUDI, D.; ZANARDI, E.; GHIDINI, S.; IANIERI, A. Biofilm formation by Staphylococcus aureus on food contact surfaces: Relationship with temperature and cell surface hydrophobicity. Food Control, v. 50, p. 930936, 2015.

CHMIELEWSKI, R. A. N.; FRANK, J. F. Biofilm formation and control in food processing facilities. Comprehensive Reviews in Food Science and Food Safety, v. 2, n.1, p. 22- 32, 2003.

COSTA, J. H. Estudo da atividade antimicrobiana de ramnolipídeos e nisina sobre Streptococcus mutans e Streptococcus oralis. 2014. 38 f. Monografia (Bacharelado) Instituto de Química de São Carlos, Universidade de São Paulo, São Carlos, 2014.

DALTIN, D. Tensoativos: química, propriedades e aplicações. São Paulo: Bluher, 2011. 43 p.

DAT, N. M.; MANH, L. D.; HAMANAKA, D.; HUNG, D. V.; TANAKA, F.; UCHINO, T. Surface conditioning of stainless steel coupons with skim milk, buttermilk, and butter serum solutions and its effect on bacterial adherence. Food Control, v. 42, p. 94-100, 2014.

DAT, N. M.; HAMANAKA, D.; TANAKA, F.; UCHINO, T. Surface conditioning of stainless steel coupons with skim milk solutions at different $\mathrm{pH}$ values and its effect on bacterial adherence. Food Control, v.21, n. 12, p. 1769-1773, 2010.

DESAI, J. D.; BANAT, I. M. Microbial production of surfactants and their commercial potential.Microbiology and Molecular Biology Reviews, v. 67, p. 47- 64, 1997.

DINGES, M. M; ORWIN, P. M; SCHLIEVERT, P. M. Exotoxins of Staphylococcus aureus.Clinical Microbiology Reviews, v.13, p.16-34, 2000.

DONLAN, R. M. Biofilms: microbial life on surfaces. Emerging Infectious Diseases, v. 8, n.9, p. 881-890, 2002.

DONLAN, R. M.; COSTERTON, J. W. Biofilms: Survival mechanisms of clinically relevant microorganisms. Clinical Microbiology Reviews, v. 15, n.2, p. 167-193, 2002.

DONNENBERG, M. S.; NARAYANAN, S. How to diagnose a foodborne illness. Infectious Disease Clinics of North America, v. 27, p. 535-554, 2013.

DONNELLY, C. W.; DIEZ-GONZALEZ, F. 2013. Listeria monocytogenes. In: LABBE, R. G.; GARCIA, S. (Ed.) Guide to foodborne pathogens. Chichester: John Wiley, 2013. p. 45-74.

DUBOIS, M.; GILLES, K. A.; HAMILTON, J. K. REBERS, P. A.; SMITH, F. Colorimetric method for determination of sugars and related compounds. Analytical Chemistry, v. 28, n. 3, p. 350- 356, 1956.

DUSANE, D. H.; NANCHARAIAH, V.; ZINJARDE, S. S.; VENUGOPALAN, V. P. Ramnolipid mediated disruption of marine Bacillus pumilus biofilms. Colloids and Surfaces B: Biointerfaces, v. 81, n.1, p. 242- 248, 2010. 
DRIESSCHE, F. V. DEN; RIGOLE, P.; BRACKMAN, G.; COENYE, T. Optimization of resazurin-based viability staining for quantification of microbial biofilms. Journal of Microbiological Methods, v. 98, p. 31-34, 2014.

FAGUNDES, H.; OLIVEIRA, C. A. F. Infecções intramamárias causadas por Staphylococcus aureus e suas implicações em paúde pública. Ciência Rural, v.34, n.4, 2004.

FAILLE,C.; JULLIEN, C.; FONTAINE, F.; BELLON-FONTAINE, M-N; SLOMIANNY, C; BENEZECH, T. Adhesion of Bacillus spores and Escherichia coli cells to inert surfaces: role of surface hydrophrobicity. Canadian Journal of Microbiology, v. 48, p. 728-738, 2002.

FARROKH, C.; JORDAN, K.; AUVRAY, F.; GLASS, K.; OPPEGAARD, H.; RAYNAUD, S.; THEVENOT, D.; CONDRON, R.; DE REU, K.; GOVARIS, A.; HEGGUM, K.; EYNDRICKX, M.; HUMMERJOHANN, J.; LINDSAY, D.; MISZCZYCHA, S.;MOUSSIEGT, S.; VERSTRAETE, K.; CERF, O. Review of shigatoxinproducing Escherichia coli (STEC) and their significance in dairy production. International Journal of Food Microbiology, v. 162, p. 190- 212, 2013

FLEMMING, H.-C; WINGENDER, J. The biofilm matrix. Nature reviews- Microbiology, v.8, p. 623-633, 2010.

GANDINI, S. C. M.; ITRI R.; SOUSA NETO, D.; TABAK, M. Porphyrin effects on zwitterionic HPS micelles as investigated by small angle X-ray scattering (SAXS) and alectron paramagnetic resonance (EPR). The Journal of Physical Chemistry B, v. 109, p. 22264-22272, 2005.

GHARAEI-FATHABAD, E. Biosurfactants in pharmaceutical industry: a mini-review. American journal of Drug Discovery and Development, v. 1, n.1, p. 58- 69, 2011.

GOMES, M. Z. V. Utilização de biossurfactantes no controle da adesãobacteriana e na remoção de biofilmes de patógenos alimentares em superfície de poliestireno. $2011.95 \mathrm{f}$. Dissertação (Mestrado em Ciências) -Instituto de Química de São Carlos, Universidade de São Paulo, São Carlos, 2011.

GOMES, M. Z. V.; NITSCHKE, M. Evaluation of rhamnolipid and surfactin to reduce the adhesion and remove biofilms of individual and mixed cultures of food pathogenic bacteria. Food Control , v. 25, p. 441-447, 2012.

GUDIÑA, E. J.; RANGARAJAN, V.; SEN, R.; RODRIGUES, L. R. Potential therapeutic applications of biosurfactants.Trends in Pharmacological Sciences, v. 34, n. 12, p. 667-675, 2013.

GUO, Y.-P.; HU, Y.-Y.; GU, R. R.; LIN, H. Characterization and micellization of rhamnolipid fractions and crude extracts produced by Pseudomonas aeruginosa mutant MIGN146. Journal of Colloid and Interface Science, v. 331, p. 356- 363, 2009.

HALL-STOODLEY, L.; COSTERTON, J. W.; STOODLEY, P. Bacterial biofilms: From the natural environment to infectious diseases. Nature Reviews Microbiology, v. 2, n. 2, p. 95108, 2004. 
HAMADI, F.; ASSERNE, F.; ELABED, S.; BENSOUDA, S.; MABROUKI, M.;

LATRACHE, H. Adhesion of Staphylococcus aureus on stainless steel treated with three types of milk. Food Control, v. 38, p.104-108, 2014.

HENKEL, M.; MÜLLER , M. M.; KÜGLER, J. H.; LOVAGLIO, R. B.; CONTIERO, J.; SYLDATK, C.; HAUSMANN, R. Rhamnolipids as biosurfactants from renewable resources: Concepts for next-generation rhamnolipid production. Process Biochemistry, v. 47, p. 1207 1219, 2012.

IBARRECHE, M. P.; CASTELLANO, P. ; VIGNOLO, G. Evaluation of anti-Listeria meat borne Lactobacillus for biofilm formation on selected abiotic surfaces. Meat Science, v. 96, p. 295- 303, 2014.

IRFAN-MAQSOOD, M.; SEDDIQ-SHAMS, M. Rhamnolipids: Well-characterized glycolipids with potential broad applicability as biosurfactants. Industrial biotechnology, v.10, n. 4, p. 285- 291, 2014.

JAGLIC, Z.; DESVAUX, M.; WEISS, A.; NESSE, L. L.; MEYER, R.L.; DEMNEROVA, K.; SCHMIDT, H.; GIAOURIS, E.; SIPAILIENE, A.; TEIXEIRA, P.; KACANIOVA, M.; RIEDEL, C. U. ; KNØCHEL, S. Surface adhesins and exopolymers of selected foodborne pathogens. Microbiology, v. 160, p. 2561- 2582, 2014.

JIANG, L-M.; HOOGENKAMP, M. A.; VAN der SLUIS, L. W. M.; WESSELINK, P. R.; CRIELAARD, W.; DENG, D. M. Resazurin metabolism assay for root canal disinfectant evaluation on dual-species biofilm. Journal of endodontics, v. 37, n. 1, 2011.

KALYOUSSEF, S.; FEJA, K. N. Foodborne Illnesses. Advances in Pediatrics, v.61, p. 287$312,2014$.

KIEREK-PEARSON, K.; KARATN, E. Biofilm development in bacteria. Advances in Applied Microbiology, v. 57, p. 79-111, 2005.

KIM, L. H.; JUNG,Y.; KIM, S.-J.; KIM, C.-M.; YU, H.-W.; PARK, H.-D.; KIM, I. S. Use of rhamnolipid biosurfactant for membrane biofouling prevention and cleaning. Biofouling, $\mathrm{v}$. 31, n. 2, p. 211- 220, 2015.

KSONTINI, H.; KACHOURF, I.; HAMDI, M. Dairy biofilm: impact of microbial community on raw milk quality. Journal of Food Quality, v. 36, p. 282- 290, 2013.

LIN, H.; ZHANG, M.; WANG, F.; MENG, F.; LIAO, B. Q.; HONG, H.; CHEN, J.; GAO, W. A critical review of extracellular polymeric substances (EPS) in membrane bioreactors: characteristics, roles in membrane fouling and control strategies. Journal of Membrane Science, v. 460, p. 110-125, 2014.

LOMONACO, S.; NUCERA, D.; FILIPELLO, V. The evolution and epidemiology of Listeria monocytogenes in Europe and the United States. Infection, Genetics and Evolution, v.35, p. 172- 183, 2015. 
LUZ, A. P.; RIBEIRO, S.; PANDOLFELLI1, V. C. Artigo revisão: Uso da molhabilidade na investigação do comportamento de corrosão de materiais refratários. Cerâmica, v. 54, p. 174$183,2008$.

MADIGAN, M. T.; MARTINKO, J. M.; DUNLAP, P. V.; CLARK, D. P. Microbiologia de Brock.Tradução de Andrea Queiroz Maranhão. 12. ed. Porto Alegre: Artmed, 2010. 1160 p.

MAFU, A. A.; ROY, D.; FOULET, J.; MAGNY, P. Attachment of Listeria monocytogenes to stainless steel, glass, polypropylene and rubber surfaces after short contact times. Journal of Food Protection, v. 53, p. 742- 6, 1990

MAGALHÃES, L. ; NITSCHKE, M. Antimicrobial activity of rhamnolipids against Listeria monocytogenes and their synergistic interaction with nisin. Food Control, v. 29, p. 138-142, 2013.

MARCHAND, S.; BLOCK, J. D.; JONGHE, V. D.; COOREVITS, A.; HEYNDRICKX, M.; HERMAN, L. Biofilm formation in milk production and processing environments; influence on milk quality and safety. Comprehensive Reviews in Food Science and Food Safety, v.11, p. 133- 147, 2012.

MARCHANT, R.; BANAT, I. M. Microbial biosurfactants: challenges and opportunities for future exploitation. Trends in Biotechnology, v. 30, n. 11, p. 558- 565, 2012.

MEYLHEUC, T.; METHIVIER, C.; RENAULT, M.; HERRY, J. M.; PRADIER, C. M.; BELLON-FONTAINE, M. N. Adsorption on stainless steel surfaces of biosurfactants produced by gram-negative and gram-positive bacteria: Consequence on the bioadhesive behaviour of Listeria monocytogenes. Colloids and Surfaces B: Biointerfaces, v. 52, p.128$137,2006$.

McLANDSBOROUGH, L.; RODRIGUEZ, A.; PÉREZ- CONESA, D.; WEISS, J. Biofilms: At the interface between biophysics and microbiology. Foods Biophysics, v. 1, n. 2, p. $94-$ 114, 2006.

McENTIRE, J. Foodborne disease: the global movement of food and people. Infectious Disease Clinics of North America, v. 27, n. 3, p. 687- 693, 2013.

MILES, A. A.; MISRA, S. S.The estimation of bacteriocidal power of the blood. Journal of Hygiene, v. 38, n. 6, p. 732-749, 1938.

MIRELES II, J. P.; TOGUCHI, A.; HARSHEY, R. M. Salmonella enterica serovar typhimurium swarming mutants with altered biofilm-forming abilities: surfactin inhibits biofilm formation. Journal of Bacteriology, v. 183, n. 20, p. 5848- 5854, 2001.

MITTELSTAEDT, S.; CARVALHO, V. M. Escherichia coli enterohemorrágica (EHEC) O157:H7- revisão. Revista do Instituto de Ciências da Saúde, v. 24, n. 3, p. 175-182, 2006

MORE, T. T.; YADAV, J. S. S.; YAN, S.; TYAGI, R. D.; SURAMPALLI, R. Y.

Extracellular polymeric substances of bacteria and their potencial enviromental applications. Journal of Environmental management, v. 144, p. 1- 25, 2014. 
MOREIRA, D. S.; LINS, U. G. C.Técnicas de microscopia para quantificação e identificação de microrganismo. Saúde \& Ambiente em Revista, v. 5, n. 2, p.01- 11, 2010.

MOSQUERA - FERNANDEZ, M.; RODRIGUEZ, L. P.; CABO, M. L.; BALSA, C. E. Numerical spatio temporal characterization of Listeria monocytogenes biofilms.

International Journal of Food Microbiology, v. 182, p. 26- 36, 2014.

MÜLLER, M. M.; KÜGLER J.H.; HENKEL, M.; GERLITZKI , M.; HÖRMANN, B.; PÖHNLEIN, M.; SYLDATK, C.; HAUSMANN, R. Rhamnolipids-next generation surfactants? Journal of Biotechnology, v. 162, n. 4, p. 366-380, 2012.

MULLIGAN, C. N. Environmental applications for biosurfactants. Environmental Pollution, v. 133, n. 2, p. 183-198, 2005.

MYSZKA, K.; CZACZYK, K. Bacterial biofilms on food contact surfaces- a review. Polish Journal of Food And Nutrition Sciences, v. 61, n.3, p. 173-180, 2011.

NICKZAD, A.; DÉZIEL, E.The involvement of rhamnolipids in microbial cell adhesion and biofilm development - an approach for control? Letters in Applied Microbiology, p. 1-7, 2013.

NITSCHKE, M.; SILVA, S. S. Recent food applications of microbial surfactants.Critical Reviews in Food Science and Nutrition, p. 1549-7852, 2016. Disponível em: <http://www.tandfonline.com/doi/pdf/10.1080/10408398.2016.1208635?needAccess=tru e.>. Acesso em: 28 set. 2016.

NITSCHKE, M.; PASTORE, G. M. Biossurfactantes: propriedades e aplicações. Química Nova, v. 25, n.5, p. 772-776, 2002.

OLIVEIRA, M. M. M.; BRUGNERA, D. F.; PICCOLI, R. H. Biofilmes microbianos na indústria de alimentos: uma revisão. Revista Instituto Adolfo Lutz, v. 69, n. 3, p.277284,2010 .

OLIVEIRA, M. M. M.; BRUGNERA, D. F.; ALVES, E. PICCOLI, R. H. biofilm formation by Listeria monocytogenes on stainless steel surface and biotransfer potential.Brazilian Journal of Microbiology, v. 41, p. 97-106, 2010.

ORSI, R. H. ; BAKKER, H. C. den; WIEDMANN, M.Listeria monocytogenes lineages: Genomics, evolution, ecology, and phenotypic characteristics. International Journal of Medical Microbiology, v. 301, n. 2, p. 79- 96, 2011.

O'TOOLE, G.; KAPLAN, H.B.; KOLTER, R. Biofilm formation as microbial development.Annual Review of Microbiology, v. 54, p. 49-79, 2000.

PAN,Y.; BREIDT, J. R. F.; KATHARIOU, S. Resistance of Listeria monocytogenes biofilms to sanitizing agents in a simulated food processing environment. Applied and Environmental Microbiology, v. 72, n. 12, p. 7711-7717, 2006.

PAULA, C. M. D De; CASARIN, L. S.; TONDO, E. C. Escherichia coliO157:H7- patógeno alimentar emergente. Vigilância Sanitária em Debate, v. 2, n. 4, p. 23- 33, 2014. 
PECORA, R. Dynamic light scattering. New York: Plenun, 1985. p. 420.

PEETERS, E.;NELIS, H.J.; COENYE, T. Comparison of multiple methods for quantification of microbial biofilms grown in microtiter plates. Journal Microbiology Methods, v. 72, n. 2, p.157-165, 2007.

PIMENTEL-FILHO, N. J.; MARTINS, M. C. F.; NOGUEIRA, G. B.; MANTOVANI, H. C.; VANETTI, M. C. D. Bovicin HC5 and nisin reduce Staphylococcus aureus adhesion to polystyrene and change the hydrophobicity profile and Gibbs free energy of adhesion.

International Journal of Food Microbiology, v.190, p. 1- 8, 2014.

PINTO, A. F. M. A. Doenças de origem microbiana transmitidas pelos alimentos. Millenium, v. 4, p. 91-100, 1996.

PLAKUNOV, V. K.; STRELKOVA, E. A.; ZHURINA, M. V. Persistence and adaptive mutagenesis in biofilms. Microbiology, v. 79, n. 4, p. 424- 434, 2010.

RAZA, Z. A., KHALID, Z. M., KHAN, M. S., BANAT, I. M., REHMAN, A., NAEEM, A., SADDIQUE, M. T. Surface properties and sub-surface aggregate assimilation of rhamnolipid surfactants in different aqueous systems. Biotechnology Letters, v. 32, n. 6, p. 811- 816, 2010.

RENDUELES, O.; GHIGO, J. M. Multi-species biofilms: How to avoid unfriendly neighbors. FEMS Microbiology Reviews, v. 36, n. 5, p. 972- 989, 2012.

REIS, R. S.; PEREIRA; A. G.; NEVES, B. C.; FREIRE,D. M.G. Gene regulation of rhamnolipid production in Pseudomonas aeruginosa - A review. Bioresource Technology, v.102, p. 6377-6384, 2011.

RIBEIRO, M. O.; GOMES, M. D. S.; SENNA, S. G.; ROSSETTI, M. L. R.; FONSECA, L. D. S. Avaliação de testes rápidos em microplacas usando indicadores de viabilidade celular para determinação da susceptibilidade de cepas de Mycobacterium tuberculosis à isoniazida e rifampicina. Jornal Brasileiro de Pneumologia, v. 30, n. 4, p. 455- 460, 2004.

RON, Z. E.; ROSENBERG, E. Natural roles of biosurfactants. Environmental Microbiology, v. 3, n.4, p. 229-236, 2001.

RONNER, A. B.; WONG, A. C. L. Biofilm development and sanitizer inactivation of Listeria monocytogenes and Salmonella typhimurium on stainless-steel and buna-N rubber.Journal Food Protection, v. 56, p. 750-758, 1993.

SAMBROOK, J.; RUSSEL, W. D. Molecular cloning: a laboratory manual. 3 ed. New York: Cold Spring Harbor Laboratory, 2001. 1885 p.

SANDBERG, M. E.; SCHELLMANN, D.; BRUNHOFER, G.; ERKER, T.; BUSYGIN, I.; LEINO, R.; VUORELA, P. M.; FALLARERO, A. Pros and cons of using resazurin staining for quantification of viable Staphylococcus aureus biofilms in a screening assay. Journal of Microbiological Methods, v. 78, p. 104-106, 2009. 
SANTOS, N. C.; CASTANHO, M. A. R. B. Teaching light scattering spectroscopy: the dimension and shape of Tobacco mosaic virus.Biophysical Journal, v. 71, p. 1641- 1650, 1996.

SCHMITZ, K. S. An introduction to dynamic light scaterring by macromolecules. Boston: Academic Press, 1990. p. 449.

SILVA, R.; CRUZ, A. G.; FARIA, J. A. F.; MOURA, M. M. L.; CARVALHO, L. M. J.; WATER, E. H. M.; SANT'ANA, A. S.Pasteurized milk: efficiency of pasteurization and its microbiological conditions in Brazil. Foodborne Pathogens and Disease, v.7, p. 217- 19, 2010 .

SINDE, E.; CARBALLO, J. Attachment of Salmonella spp. and Listeria monocytogenes to stainless steel, rubber and polytetrafluorethylene: the influence of free energy and the effect of commercial sanitizers. Food Microbiology, v.17, p. 439- 447, 2000.

SOTIROVA, A. V.; SPASOVA, D. I.; GALABOVA, D. N.; KARPENKO, E.; SHULGA, A. Rhamnolipid-biosurfactant permeabilizing effects on Gram-positive and Gram-negative bacterial strains. Current Microbiology, v. 56, p. 639- 644, 2008.

SREY, S.; JAHID, I. K.; HA, S-D. Biofilm formation in food industries: a food safety concern. Food Control, v. 31, p. 572- 585, 2013.

SREY, S.; PARK, S. Y.; JAHID, I. K.; OH, S.- R; HAN, N.; ZHANG, C.- Y; KIM, S.- H.; CHO, J.- I.; HA, S.- D. Evaluation of the removal and destruction effect of a chlorine and thiamine dilauryl sulfate combined treatment on L. monocytogenes biofilm. Foodborne Pathogens and Disease, v. 11, n. 8, p. 658- 663, 2014.

SUTHERLAND, I. W. The biofilm matrix - An immobilized but dynamic microbial environment. Trends in Microbiology, v. 9, n. 5, p. 222- 227, 2001.

SVERGUN, D. I.; FEIGIN, L. A. Struture analysis by small-angle X-ray and neutron scattering. New York: Plenum, 1987. 335 p.

TODD, E. C. D. The international risk governance council framework and its application to Listeria monocytogenes in soft cheese made from unpasteurised milk. Food Control, v. 22, p. 1513-24, 2011.

TORIBO, J.; ESCALANTE, A. E.; SOBERÓN-CHÁVEZ, G. Rhamnolipids: production in bacteria other than Pseudomonas aeruginosa. European Journal of Lipid Science and Technology, v. 112, p. 1082-1087, 2010.

TORTORA, G. J.; FUNKE, B. R.; CASE, C. L, Microbiologia. 8 ed. Porto Alegre: Artemed, 2005. 894 p.

TUMMINO, P. J.; GAFNI, A. Determination of the aggregation number of detergent micelles using steady-state fluorescence quenching. Biophysical Journal, v. 64, p. 1580-1587, 1993. 
TRENTIN, D. S.; GIORDANI, R. B.; MACEDO, A. J. Biofilmes bacterianos patogênicos: aspectos gerais, importância clínica e estratégias de combate. Revista Liberato, v. 14, n. 22, p. 113-238, 2013.

VAZQUEZ-SANCHEZ, D.; HABIMANA, O.; HOLCK, A. Impact of food-related environmental factors on the adherence and biofilm formation of natural Staphylococcus aureusisolates. Current Microbiology, v. 66, p.110-121, 2013.

VISVALINGAM, J.; HOLLEY, R. A. Adherence of cold-adapted Escherichia coli O157:H7 to stainless steel and glass surfaces. Food Control, v. 30, n. 2, p. 575-579, 2013.

VU, B.; CHEN, M.; CRAWFORD, R. J.; IVANOVA, E. P. Bacterial extracellular polysaccharides involved in biofilm formation. Molecules, v. 14, n.7, p. 2535- 2554, 2009.

WEILER, C.; IFLAND, A.; NAUMANN, A.; KLETA, S.; NOLL, M. Incorporation of Listeria monocytogenes strains in raw milk biofilms. International Journal of Food Microbiology, v.161, p. 61- 68, 2013.

WIRTANEN, G; HUSMARK U; MATTILA-SANDHOLM T. Microbial evaluation of the biotransfer potencial from surfaces with Bacillus biofilms after rinsing and cleaning procedures in closed foodprocessing systems. Journal Food Protection, v. 59, p: 727-733. 1996.

ZAIA, D. A. M.; ZAIA, C. T. B. V.; LICHITIG, J. Determinação de proteínas totais via espectrofotometria: vantagens e desvantagens dos métodos existentes. Química Nova, v. 21, n. 6, p. 787- 793, 1998.

ZERAIK, A. E. Biossurfactantes como agentes inibidores da adesão de patógenos em superfícies de poliestireno. 2009. 135 f. Dissertação (Mestrado em Ciências) - Instituto de Química de São Carlos, Universidade de São Paulo, São Carlos, 2009.

ZERAIK, A. E.; NITSCHKE, M. Influence of growth media and temperature on bacterial adhesion to polystyrene surfaces.Brazilian Archives of Biology and Technology, v. 55, p. 569- 576, 2012. 